\title{
Influence of Boron on Some Properties of Experimental and Commercial Steels
}

\author{
By Thomas G. Digges and Fred M. Reinhart
}

\begin{abstract}
Tests were made to determine the influence of boron additions with simple and complex intensifiers on the cleanliness, structure, austenite, and McQuaid-Ehn grain sizes, hardenability, notch toughness (Charpy impact) at room and low temperatures and tensile properties of "split" heats of both experimental and commercial steels. The testing program with the experimental steels was extended to include a study of the effect of deoxidation on the above properties and the influence of boron on transformation temperatures and weldability and the recovery of boron on remelting.

Boron was determined chemically by a distillation-colorimetric method, or spectrographically, and in some steels by both methods.

The presence of boron had no significant influence on the cleanliness, hot-working, transformation temperatures, softening by tempering, weldability, or tensile properties of the steels. However, boron lowered the coarsening temperature of austenite. The hardenability of many of the experimental, and all of the commercial steels, was markedly increased by boron, but no correlation was found between hardenability and the amount of boron added or retained in the steels. Thus the magnitude of the effect of boron on hardenability appears to depend upon the form in which it exists in austenite and not necessarily upon the amount present. The hardenability of steels with high-soluble nitrogen was not materially enhanced by boron, but it was possible to retain its effect in high-nitrogen steels (low-soluble nitrogen) by fixing the nitrogen was nitrides.

A small amount of boron was often beneficial to notch toughness at room temperature of steels when fully hardened and tempered at low temperatures whereas its presence, especially in relatively large amounts, was usually either without effect or was detrimental to notch toughness at room and low temperatures when the hardened steels were tempered at high temperatures.
\end{abstract}

\section{Introduction}

It is now recognized that the hardenability of some types of steel is materially improved by the addition of small amounts of boron. Apparently, the effectiveness of the treatment with boron depends upon the steel-making practice and the amount and form of boron retained in the steels. The optimum effect on hardenability is obtrined when boron is added in the form of simple or complex ferroalloys, commonly called "intensifiers," "special addition agents" or "needling agents," to thoroughly deoxidized heats in which the amount recovered is within the range of about 0.001 to 0.005 percent. As one of the main roles of alloying elements in steels is to increase the depth of hardening or hardenability, this significant effect of boron suggested the possibility that it might be substituted for a part or all of the strategic elements commonly used as alloying agents in steels.

During 1917-20, a study was made at the National Bureau of Standards [1] ${ }^{1}$ in cooperation with the Bureau of Mines, to determine the effect of boron and other elements on some properties of steels for light armor. The boron steels were difficult to hot roll into plates because of a complex eutectic that was fusible at the temperatures used.

\footnotetext{
${ }^{1}$ Figures in brackets indicate the literature references at end of this paper.
} 
The boron steels also had relatively low ductility, and it was stated that this group could almost be dismissed from further consideration. However, the boron in these steels ranged from about 0.06 to 0.6 percent, and it was soon thereafter claimed that an addition of 0.001 percent boron was sufficient to change the structure of iron-carbon alloys, and 0.007 to 0.010 percent made a "selfhardening"' (deep-hardening) steel [2].

The present investigation was carried out at the National Bureau of Standards under the auspices of the War Metallurgy Committee, National Research Council to which funds were transferred by the Office of Scientific Research and Development to carry on the project $(\mathrm{NRC}-31)$ for a period extending from October 1942 to September 1944. The plans for the investigation were prepared jointly with a representative of the War Metallurgy Committee and in addition, the testing: program for the commercial steels was prepared with, and approved by, the Subcommittee on Special Addition Agent Steels of the War Engineering Board, Iron and Steel Committee, and Army Ordnance. The purpose of the investigation was to determine quantitatively the effects of boron on some properties of steels used for armor plate and other military applications, and it was divided into two main parts; namely, (1) a study of the interrelationship between boron, carbon, and alloying constituents on some of the properties of steels made in the laboratory, and (2) a study of the properties of boron-treated steels of selected chemical composition made commercially under predetermined deoxidizing practices. Special attention was to be directed to the development of spectrographical and chemical methods for the accurate determination of small amounts of boron in steel. A study was made of the cleanliness and structures of the steels as hot-rolled, normalized and heat-treated; determinations were made of the austenite and McQuaid-Ehn grain sizes, hardenability (Jominy), notch toughness (Charpy impact) at room and low temperatures and tensile properties at room temperature. The investigation was extended with experimental steels to include a study of the effect of deoxidation practice and composition of ferroalloys containing boron on the recovery of boron and its influence on the above properties; a determination of the recovery of boron on remelting in an induction furnace under both slightly and strongly deoxidizing conditions; and the determination of the effect of boron on the transformation temperatures $\left(A_{1}\right.$, $A_{3}$ and $\left.A r^{\prime \prime}\right)$ and weldability of some of the experimental steels. The results obtained during the course of the investigation were presented in some detail in progress reports to the sponsor and issued as restricted reports through the Office of Scientific Research and Development [3 to 12, incl.].

The present paper includes a complete presentation of these data on hardenability and impact testing and only a summary of the remaining test data.

\section{Steels \\ 1. Composition}

The chemical composition of the experimental steels is given in tables 1 to 7 and that of the commercial steels in table 8 . (The term "none" as used in the tables and figures means not added or determined.)

The experimental steels are grouped according to heats, and the ingots comprising a heat are numbered to increase consecutively in most cases with the order of pouring; each ingot was assigned a separate number. The commercial steels are designated by numerals prefixed by the letter, $C$.

TABLE 1.-Chemical composition (percentage by weight) of experimental carbon-manganese steels

\begin{tabular}{|c|c|c|c|c|c|c|c|c|c|c|}
\hline \multicolumn{2}{|c|}{ Identification } & \multirow[b]{2}{*}{$\mathrm{C}$} & \multirow[b]{2}{*}{$\mathrm{Mn}$} & \multirow[b]{2}{*}{$\mathrm{P}$} & \multirow[b]{2}{*}{ S } & \multirow[b]{2}{*}{$\mathrm{Si}$} & \multirow[b]{2}{*}{ Al } & \multirow{2}{*}{$\begin{array}{c}\mathrm{N}^{2} \\
\text { Total }\end{array}$} & \multicolumn{2}{|c|}{ Boron 1} \\
\hline $\begin{array}{l}\text { Heat } \\
\text { No. }\end{array}$ & $\begin{array}{c}\text { Steel } \\
\text { No. }\end{array}$ & & & & & & & & Added & $\begin{array}{c}\text { Recov- } \\
\text { ered }\end{array}$ \\
\hline $8888-1$ & 9 & 0.21 & 1.54 & 0.012 & 0.020 & 0.28 & & & None & $(3)$ \\
\hline $8888-2$ & 10 & .20 & 1.58 & $\ldots \ldots$ & & .24 & & & 0.0015 & 0.0012 \\
\hline $8888-3$ & 11 & .20 & 1.55 & & - - n. & .25 & & - & .003 & .0028 \\
\hline $8888-4$ & 12 & .18 & 1.50 & & $\ldots$ & .25 & & & .006 & .0062 \\
\hline $8889-1$ & 1 & .29 & 1. 60 & .011 & $.0 \check{0} 0$ & .26 & & 0.006 & None & (3) \\
\hline $8889-2$ & 2 & .28 & 1. 60 & -..... & .... & .23 & 0.05 & .005 & 0.0015 & .0015 \\
\hline $8889-3 \ldots$ & 3 & .27 & 1.59 & & & .26 & .06 & .006 & .003 & .0030 \\
\hline $8889-4$ & 4 & .27 & 1. 61 & $\ldots . .$. & ..... & .26 & .05 & .005 & .006 & .0060 \\
\hline $8890-1 \ldots$ & 5 & .47 & 1. 56 & .011 & .020 & .24 & & & None & $\left({ }^{3}\right)$ \\
\hline $8890-2$ & 6 & .47 & 1.58 & $\ldots$. & 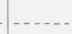 & .23 & & & 0.0015 & .0015 \\
\hline $8890-3$ & 7 & .46 & 1.57 & & & .23 & & & .003 & .0033 \\
\hline $8890-4 \ldots$ & 8 & .44 & 1.57 & -..... & - & .23 & & & .006 & .0062 \\
\hline $8892-1 \ldots$ & 17 & .29 & 0.82 & .010 & .021 & .24 & & & None & $<.0001$ \\
\hline $8892-2$ & 18 & .30 & .82 & & & .23 & & & 0.0015 & .0016 \\
\hline $8892-3 \ldots$ & 19 & .29 & .82 & & & .23 & & & .003 & .0031 \\
\hline $8892-4 \ldots$ & 20 & .28 & .79 & . & $\ldots .$. & .22 & & & .006 & .0065 \\
\hline $8891-1 \ldots$ & 13 & .29 & 1. 26 & .018 & .021 & .23 & & & None & $\left({ }^{3}\right)$ \\
\hline $8891-2 \ldots$ & 14 & .28 & 1. 25 & $\ldots$ & & .23 & & & 0.0015 & .0020 \\
\hline $8891-3 \ldots$ & 15 & .28 & 1. 25 & & & .23 & & & .003 & .0035 \\
\hline $8891-4 \ldots$ & 16 & .27 & 1. 24 & & & .23 & & & .006 & .0069 \\
\hline
\end{tabular}

1 'wo pounds of aluminum per ton ( 0.10 percent) were added to each heat before making the boron additions with Ferroboron as required in the furnace.

2 Determinations were made by the racuum-fusion method.

3 When no boron was added, determinations of boron recovered usually were not made. 
TABLE 2.-Chemical composition (percentage by weight) of experimental carbon-manganese steels prepared with different deoxidation practices

The chemical composition of steels $1,2,3$, and 4, deoxidized with 0.10 percent of aluminum is given in table 1 . These steels are also included in a study of the properties as affected by deoxidation practice.

The boron additions were made as required in the furnace.

\begin{tabular}{|c|c|c|c|c|c|c|c|c|c|c|c|c|c|c|}
\hline \multicolumn{2}{|c|}{ Identification } & \multirow{3}{*}{$\mathrm{C}$} & \multirow{3}{*}{$\mathrm{Mn}$} & \multirow{3}{*}{$\mathrm{P}$} & \multirow{3}{*}{$\mathrm{S}$} & \multirow{3}{*}{$\mathrm{Si}$} & \multirow{3}{*}{$\mathrm{Ti}$} & \multirow{3}{*}{$\mathrm{Zr}$} & \multirow{3}{*}{$\mathrm{Al}$} & \multirow{3}{*}{$\mathrm{N}^{2}$} & \multicolumn{4}{|c|}{ Boron } \\
\hline \multirow[b]{2}{*}{ Heat No. } & \multirow{2}{*}{$\begin{array}{l}\text { Steel } \\
\text { No. }\end{array}$} & & & & & & & & & & \multirow[b]{2}{*}{ Added } & \multicolumn{3}{|c|}{ Recovered } \\
\hline & & & & & & & & & & & & $\begin{array}{c}\text { Acid } 1 \\
\text { soluble }\end{array}$ & $\begin{array}{l}\text { Acid } 1 \\
\text { insolu- } \\
\text { ble }\end{array}$ & Total \\
\hline \multicolumn{15}{|c|}{ TREATED WITH $0.05 \%$ Al; BORON ADDITIONS MADE WITH GRAINAL NO. 79} \\
\hline $9362-1 \ldots$ & 76 & 0.30 & 1. 64 & 0.11 & 0.027 & 0.24 & $<0.01$ & 0.005 & 0.02 & & None & & & \\
\hline $9362-2 \ldots$ & 77 & .30 & 1. 62 & & & .24 & .02 & .003 & .02 & & 0.00035 & 0.0001 & None & 0.0001 \\
\hline $9362-3 \ldots \ldots$ & 78 & .30 & 1. 61 & & & .24 & .02 & .003 & .01 & & .00075 & .0002 & 0.0002 & .0004 \\
\hline $9362-4$ & 79 & .29 & 1. 64 & & & .25 & .03 & .004 & .04 & & .0015 & .0004 & .0002 & .0006 \\
\hline $9362-5 \ldots$ & 80 & .29 & 1. 62 & & & .24 & .03 & .004 & .04 & & .003 & .0008 & None & .0008 \\
\hline $9362-6 \ldots$ & 81 & .29 & 1. 62 & & & .25 & .03 & .004 & .02 & & .006 & .0017 & ......do_... & .0017 \\
\hline
\end{tabular}

NOT TREATED WITH Al; BORON ADDITIONS MADE WITH GRAINAL NO. 79

\begin{tabular}{|c|c|c|c|c|c|c|c|c|c|c|c|c|c|c|}
\hline $9089-1 \ldots \ldots$ & 33 & 0.28 & 1. 59 & 0.011 & 0.034 & 0.25 & & & & 0.006 & None & & & \\
\hline $9089-2 \ldots \ldots$. & 34 & .29 & 1. 59 & & 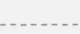 & .26 & 0.17 & 0.01 & 0.03 & .006 & 0.0015 & 0.0010 & None & 0.0010 \\
\hline $9089-3 \ldots \ldots$ & 35 & .28 & 1.62 & & & .26 & .22 & .01 & .05 & .006 & .003 & .0018 & None & .0018 \\
\hline $9089-4 \ldots$ & 36 & .28 & 1.65 & $\ldots$ & (n) & .31 & .29 & .02 & .08 & .006 & .006 & .0033 & None & .0033 \\
\hline
\end{tabular}

NOT TREATED WITH Al; BORON ADDITIONS MADE WITH SYNTHETIC MIXTURE OF COMPOSITION SIMILAR TO GRANIAL NO. 79

$9090-$

$9090-2$

$9090-3$

$9090-4$

\begin{tabular}{|c|c|c|c|c|c|c|c|c|c|c|c|c|c|}
\hline 37 & 0.30 & 1. 61 & 0.008 & 0.030 & 0.25 & & & & 0.005 & None & & & \\
\hline 38 & .30 & 1. 60 & & & .27 & 0.16 & 0.004 & 0.02 & 0.006 & 0.0015 & 0.0014 & None & 0.0014 \\
\hline 39 & .30 & 1. 60 & & & .28 & .20 & .006 & .04 & 0.005 & .003 & .0024 & None & .0024 \\
\hline 40 & .29 & 1. 67 & & & .27 & .22 & .007 & .07 & .006 & .006 & .0051 & None & .0051 \\
\hline
\end{tabular}

NOT TREATED WITH Al;TREATED WITH SYNTHETIC MIXTURE OF COMPOSITION SIMILAR TO GRAINAL NO.79 EXCEPT THAT BORON WAS OMITTED

\begin{tabular}{|c|c|c|c|c|c|c|c|c|c|c|c|c|c|c|}
\hline $9450-1^{3}$ & 110 & 0.29 & 1. 64 & 0.008 & 0.029 & 0.30 & & & & & None & & & \\
\hline $9450-2^{4}$ & 111 & .29 & 1. 60 & & (........ & .27 & 0.03 & 0.006 & 0.01 & 0.010 & None & & & \\
\hline $9450-3^{5}-\ldots$ & 112 & .28 & 1. 69 & & & .30 & .05 & .007 & .005 & - n & None & & & \\
\hline $9450-4^{6}+\ldots \ldots$ & 113 & .29 & 1. 72 & 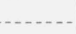 & $\ldots$ & .29 & .09 & .007 & .09 & .011 & None & & & \\
\hline
\end{tabular}

TREATED WITH $0.10 \%$ Al; BORON ADDITIONS MADE WITH SILCAZ NO. 3

\begin{tabular}{|c|c|c|c|c|c|c|c|c|c|c|c|c|c|c|}
\hline $9360-1$ & 64 & 0.30 & 1. 64 & 0.012 & 0.026 & 0.25 & 0.01 & 0.005 & 0.06 & & None & & & \\
\hline $9360-2$ & 65 & .29 & 1.64 & & & .27 & $<.01$ & .005 & .06 & 0.006 & 0.00035 & 0.0002 & 0.0001 & 0.0003 \\
\hline $9360-3$ & 66 & .29 & 1. 66 & & & .29 & .02 & .005 & .05 & ... & .00075 & .0004 & .0002 & .0006 \\
\hline $9360-4$ & 67 & .30 & 1. 63 & & & .36 & .02 & .005 & .06 & -....... & .0015 & .0005 & .0003 & .0008 \\
\hline $9360-5$ & 68 & .29 & 1.65 & & & .41 & .02 & .007 & .06 & - & .003 & .0025 & None & .0025 \\
\hline $9360-6 \ldots$ & 69 & .29 & 1. 66 & & & .57 & .03 & .004 & .07 & .009 & .006 & .0041 & None & .0041 \\
\hline \multicolumn{15}{|c|}{ NOT TREATED WITH AI; BORON ADDITIONS MADE WITH SILCAZ NO. 3} \\
\hline $9361-1 \ldots$ & 70 & 0.30 & 1. 54 & 0.013 & 0.030 & 0.19 & $<0.01$ & 0.003 & Nil & & None & & & \\
\hline $9361-2$ & 71 & .30 & 1.54 & & & .21 & $<.01$ & .006 & Nil & & 0.00035 & 0.0004 & None & 0.0004 \\
\hline $9361-3$ & 72 & .31 & 1.56 & & & .26 & .02 & .003 & Nil & - & .00075 & .0005 & 0.0001 & .0006 \\
\hline $9361-4+25-1$ & 73 & .30 & 1.55 & & & .23 & .02 & .003 & Nil & 0.006 & .0015 & .0008 & .0007 & .0015 \\
\hline $9361-5$ & 74 & .30 & 1. 56 & & & .36 & .03 & .004 & 0.01 & - n-..... & .003 & .0027 & None & .0027 \\
\hline $9361-6 \ldots$ & 75 & .30 & 1. 56 & & & .50 & .03 & .004 & .02 & .010 & .006 & .0086 & None & .0086 \\
\hline
\end{tabular}

1:1 phosphoric.

2 Determinations were made by the vacuum-fusion method.

${ }^{3}$ Not treated with synthetic mixture.

4 Same amount of synthetic mixture as for steel 38 .

${ }^{5}$ Same amount of synthetic mixture as for steel 39.

${ }^{6}$ Same amount of synthetic mixture as for steel 40 . 
$\mathrm{T}_{\mathrm{ABI}} \mathrm{E}$ 3.-Chemical composition (percentage by weight) of experimental nitrogen steels

\begin{tabular}{|c|c|c|c|c|c|c|c|c|c|c|c|c|c|c|c|c|c|c|c|}
\hline \multicolumn{2}{|c|}{ Identification } & \multirow{3}{*}{$\mathrm{C}$} & \multirow{3}{*}{ Mn } & \multirow{3}{*}{1} & \multirow{3}{*}{$\mathrm{Cr}$} & \multirow{3}{*}{$\begin{array}{l}\text { Al } \\
\text { (to- } \\
\text { tal) }\end{array}$} & \multicolumn{2}{|c|}{$\mathrm{Ti}$} & \multicolumn{2}{|c|}{$\mathrm{Zr}$} & \multicolumn{4}{|c|}{$\mathrm{N}$} & \multicolumn{4}{|c|}{ Boron ${ }^{3}$} & \multirow{3}{*}{ Ferroalloy } \\
\hline \multirow{2}{*}{ Heat No. } & \multirow{2}{*}{$\begin{array}{l}\text { Steel } \\
\text { No. }\end{array}$} & & & & & & \multirow{2}{*}{$\begin{array}{c}\text { Add- } \\
\text { ed }\end{array}$} & \multirow{2}{*}{$\begin{array}{l}\text { Re- } \\
\text { cov- } \\
\text { ered }\end{array}$} & \multirow{2}{*}{$\begin{array}{c}\text { Add } \\
\text { ed }\end{array}$} & \multirow{2}{*}{$\begin{array}{l}\text { Re- } \\
\text { cov- } \\
\text { ered }\end{array}$} & \multirow{2}{*}{$\begin{array}{c}\text { Vac- } \\
\text { uum } \\
\text { fusion }\end{array}$} & \multicolumn{2}{|c|}{$\begin{array}{c}\text { Allen } \\
\text { method } \\
\text { (modified) }\end{array}$} & \multirow{2}{*}{$\begin{array}{l}\text { Av. } \\
\text { (to- } \\
\text { tal) }\end{array}$} & \multirow{2}{*}{$\begin{array}{c}\text { Add- } \\
\text { ed }\end{array}$} & \multicolumn{3}{|c|}{ Recovered } & \\
\hline & & & & & & & & & & & & $\begin{array}{l}\text { Acid } \\
\text { solu- } \\
\text { ble } 1\end{array}$ & $\begin{array}{l}\text { To- } \\
\text { tal }^{2}\end{array}$ & & & $\begin{array}{l}\text { Acid } \\
\text { solu- } \\
\text { ble } 4\end{array}$ & $\begin{array}{l}\text { Acid } \\
\text { insol- } \\
\text { uble } 4\end{array}$ & Total & \\
\hline
\end{tabular}

STEELS WITH LOW NITROGEN

\begin{tabular}{|c|c|c|c|c|c|c|c|c|c|c|c|c|c|c|c|c|c|c|c|c|c|}
\hline $9079-1 \ldots$ & 41 & 0.30 & 1. 66 & 0.010 & 0.020 & 0.20 & None & 0.055 & None & & None & & 0.003 & & 0.004 & 0.0035 & None & & & & None. \\
\hline $9079-2$ & 42 & .29 & 1.64 & $\ldots$ & & .20 & None & .041 & None & & None & & .003 & & .003 & .003 & 0.006 & 0.0031 & 0.0011 & 0.0042 & Ferroboron. \\
\hline $9079-3 \ldots$ & 43 & .30 & $1.6 i$ & - & - & .20 & None & .048 & 0.20 & 0.13 & None & & .003 & & .004 & .0035 & .006 & .0044 & 4 None & .0044 & Do. \\
\hline 9699-1. & 138 & .30 & 1. 68 & .010 & .029 & .29 & None & & None & & None & & .005 & & & .005 & None & & & & None. \\
\hline $9699-2 \ldots$ & 139 & .29 & 1.67 & - & - & .28 & None & & None & & None & & .005 & 0.005 & & .005 & 0.0015 & .0005 & 0.0011 & .0016 & Ferroboron. \\
\hline $9699-3 \ldots$ & 140 & .29 & 1. 63 & & & .32 & None & & None & 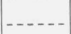 & None & & .006 & .005 & - & .006 & .0030 & .0012 & 2.0018 & \begin{tabular}{|l|}
.0030 \\
\end{tabular} & Do. \\
\hline $9699-4$ & 141 & .29 & 1.65 & & & .36 & None & & 0.20 & .12 & None & & .006 & .002 & .007 & .006 & .0030 & .0022 & 2.0013 & 3.0035 & Do. \\
\hline $9699-5$ & 142 & .29 & 1. 67 & & & .31 & None & & .06 & .03 & 0.01 & $<0.01$ & .004 & .002 & -.... & .004 & .0015 & 5.0009 & 9.0001 & .0010 & Grainal No.79. \\
\hline $9699-6 \ldots$ & 143 & .28 & 1. 68 & .. & - & .29 & None & -.. & .20 & .11 & None & -.... & .006 & .001 & .007 & .007 & .0015 & .0014 & 4.0001 & .0015 & Ferroboron. \\
\hline
\end{tabular}

STEELS WITH INTERMEDIATE NITROGEN

\begin{tabular}{|c|c|c|c|c|c|c|c|c|c|c|c|c|c|c|c|c|c|c|c|c|c|}
\hline $9080-1 \ldots$ & 44 & 0.24 & 1. 64 & 0.018 & 0.031 & 0.33 & None & 0.060 & None & & None & & 0.008 & & 0.009 & 0.0085 & None & & & & None. \\
\hline $9080-2$ & 45 & .24 & 1. 65 & & - & .33 & None & .037 & None & & None & & .011 & & .006 & .0085 & 0.006 & 0.0031 & 0.0028 & 0.0059 & Ferroboron. \\
\hline $9080-3 \ldots$ & 46 & .21 & 1. 63 & 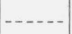 & $\ldots$ & .35 & None & .043 & 0.20 & 0.20 & None & & .011 & & .011 & .011 & .006 & .0053 & & .0053 & Do. \\
\hline $9700-1 \ldots$ & 144 & .30 & 1. 56 & .009 & .030 & .22 & None & & None & & None & & .007 & & $\ldots$ & .007 & None & & & & None. \\
\hline $9700-2$ & 145 & .30 & 1. 56 & 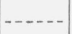 & - & .22 & None & & None & & None & & .009 & & .009 & .009 & 0.0015 & .0007 & .0011 & .0018 & Ferroboron. \\
\hline $9700-3 \ldots$ & 146 & .30 & 1. 56 & & & .23 & None & & None & $\therefore$ & None & & .010 & 0.009 & .008 & .009 & .0030 & .0014 & .0012 & .0026 & Do. \\
\hline $9700-4 \ldots$ & 147 & .29 & 1.56 & & & .26 & None & & 0.20 & .11 & None & & .010 & .004 & .015 & .013 & .0030 & .0023 & .0014 & .0037 & Do. \\
\hline $9700-5 \ldots$ & 148 & .29 & 1. 56 & & & .22 & None & & .06 & .02 & 0.01 & $<0.01$ & .008 & .003 & .011 & .010 & .0015 & .0005 & .0005 & .0010 & Grainal No. 79 \\
\hline $9700-6$ & 149 & .29 & 1. 55 & & & .23 & None & & .20 & .11 & None & & .008 & .003 & .012 & .010 & .0015 & .0015 & .0005 & .0020 & Ferroboron. \\
\hline
\end{tabular}

STEELS WITH HIGH NITROGEN

\begin{tabular}{|c|c|c|c|c|c|c|c|c|c|c|c|c|c|c|c|c|c|c|c|c|c|}
\hline $9081-1 \ldots$. & 47 & 0.26 & 1.65 & 0.016 & 0.031 & 0.27 & None & 0.054 & None & & None & & 0.015 & & 0.013 & 0.014 & None & & & & Non \\
\hline $9081-2 \ldots$ & 48 & .26 & 1. 67 & $\cdots$ & |... & .27 & None & .044 & None & - . & None & & .015 & & 011 & .013 & 0.006 & 0.0022 & 0.0031 & 10.0053 & Ferroboron. \\
\hline $9081-3 \ldots$ & 49 & .26 & 1.65 & & & .31 & None & .053 & 0.20 & 0.17 & None & & .016 & & .014 & .015 & .006 & .0049 & None & e. .0049 & Do. \\
\hline $9701-1$ & $1 E 0$ & .32 & 1. 62 & .011 & .028 & .25 & None & & Nore & & None & & .014 & & & .014 & None & & & & Non \\
\hline $9701-2 \ldots$ & 151 & .30 & 1. 64 & & & .25 & None & & None & & None & & .013 & 0.017 & & .013 & 0.0015 & 5.0006 & 0.0011 & 1.0017 & Ferroboron. \\
\hline $9701-3 \ldots$ & 152 & .30 & 1. 54 & & & .29 & Nore & & None & & None & & .018 & .016 & & .018 & .0030 & .0019 & .0013 & 3.0032 & Do. \\
\hline $9701-4 \ldots$ & 153 & .31 & 1. 60 & & & .29 & None & & 0.20 & .10 & None & & .017 & .002 & $\cdots$ & .017 & .0030 & .0023 & .0002 & 2.0025 & Do. \\
\hline $9701-5 \ldots$ & 154 & .30 & 1. 62 & & & .24 & None & & .06 & .02 & 0.01 & $<0.01$ & .014 & .008 & .015 & .014 & .0015 & 5.0004 & 4.0005 & 5.0009 & Grainal No. 79 \\
\hline $9701-6 \ldots$ & 155 & .30 & 1. 63 & & & .25 & None & & .20 & .06 & None & & .015 & .001 & .016 & .016 & .0015 & 5.0013 & 3.0000 & 0.0013 & Ferroboron. \\
\hline $10138-1 \ldots$ & 180 & .29 & 1. 54 & .012 & .026 & .21 & None & & None & & None & & & .028 & .027 & .027 & None & & & & None. \\
\hline $10138-2 \ldots$ & 181 & .29 & 1.55 & & & .23 & None & & None & & None & & & .026 & .025 & .025 & 0.0015 & .0007 & .0007 & 7.0014 & Ferroboron. \\
\hline $10138-3 \ldots$ & 182 & .28 & 1. 46 & & & .24 & None & & 0.20 & .17 & None & & .017 & .002 & .017 & .017 & .0015 & 5.0014 & .0005 & 5.0019 & Do. \\
\hline $10138-4$ & 183 & .29 & 1. 49 & & & .23 & None & & .06 & .02 & 0.01 & $<.01$ & .022 & .020 & .019 & .021 & .0015 & .0006 & .0000 & 0.0006 & Grainal No. 79 . \\
\hline $10138-5 \ldots$ & 184 & .29 & 1. 55 & & & .22 & Nore & & None & $\ldots$ & None & & & .025 & .023 & .023 & .0030 & .0010 & .0016 & 6.0026 & Ferroboron. \\
\hline $10138-6 \ldots$ & 185 & .28 & 1.55 & & - & .23 & None & & 0.20 & .15 & None & - & $\ldots$ & .001 & .024 & .024 & .0030 & 0024 & .0000 & .0024 & Do. \\
\hline
\end{tabular}

See footnotes at end of table. 
TABLE 3.-Chemical composition (percentage by weight) of experimental nitrogen steels-Continued

\begin{tabular}{|c|c|c|c|c|c|c|c|c|c|c|c|c|c|c|c|c|c|c|c|c|c|}
\hline \multicolumn{2}{|c|}{ Identification } & \multirow{3}{*}{$\mathrm{C}$} & \multirow{3}{*}{$\mathrm{Mn}$} & \multirow{3}{*}{$\mathrm{P}$} & \multirow{3}{*}{$\mathrm{s}$} & \multirow{3}{*}{$\mathrm{Si}$} & \multirow{3}{*}{$\mathrm{Cr}$} & \multirow{3}{*}{$\begin{array}{c}\mathrm{Al} \\
\text { (to- } \\
\text { tal) }\end{array}$} & \multicolumn{2}{|c|}{$\mathrm{Ti}$} & \multicolumn{2}{|c|}{$\mathrm{Zr}$} & \multicolumn{4}{|c|}{$\mathrm{N}$} & \multicolumn{4}{|c|}{ Boron ${ }^{3}$} & \multirow{3}{*}{ Ferroalloy } \\
\hline \multirow{2}{*}{ Heat No. } & \multirow{2}{*}{$\begin{array}{l}\text { Steel } \\
\text { No. }\end{array}$} & & & & & & & & \multirow{2}{*}{$\begin{array}{c}\text { Add- } \\
\text { ed }\end{array}$} & \multirow{2}{*}{$\begin{array}{l}\text { Re- } \\
\text { cov- } \\
\text { ered }\end{array}$} & \multirow{2}{*}{$\begin{array}{c}\text { Add- } \\
\text { ed }\end{array}$} & \multirow{2}{*}{$\begin{array}{l}\text { Re- } \\
\text { cov- } \\
\text { ered }\end{array}$} & \multirow{2}{*}{$\begin{array}{c}\text { Vac- } \\
\text { uum } \\
\text { fusion }\end{array}$} & \multicolumn{2}{|c|}{$\begin{array}{c}\text { Allen } \\
\text { method } \\
\text { (modified) }\end{array}$} & \multirow{2}{*}{$\begin{array}{l}\text { Av. } \\
\text { (to- } \\
\text { tal) }\end{array}$} & \multirow{2}{*}{$\begin{array}{l}\text { Add- } \\
\text { ed }\end{array}$} & \multicolumn{3}{|c|}{ Recovered } & \\
\hline & & & & & & & & & & & & & & $\begin{array}{l}\text { Acid } \\
\text { solu- } \\
\text { ble } 1\end{array}$ & $\begin{array}{l}\text { To- } \\
\mathrm{tal}^{2}\end{array}$ & & & $\begin{array}{l}\text { A cid } \\
\text { solu- } \\
\text { ble }\end{array}$ & $\begin{array}{l}\text { Acid } \\
\text { insol- } \\
\text { uble }\end{array}$ & Total & \\
\hline
\end{tabular}

\section{STEELS WITH HIGH NITROGEN WITHOUT AND WITH TITANIUM}

\begin{tabular}{|c|c|c|c|c|c|c|c|c|c|c|c|c|c|c|c|c|c|c|c|c|c|}
\hline $9702-1 \ldots$ & 156 & 0.31 & 1. 60 & 0.010 & 0.028 & 0.25 & None & & None & & None & & 0.015 & 0.016 & 0.018 & 0.017 & 0.0015 & 0.0005 & 0.0008 & 0.0013 & Ferroboron. \\
\hline $9702-2$ & 157 & .32 & 1. 62 & & & .24 & None & & 0.025 & 0.01 & None & & & .015 & .020 & .020 & .0015 & .0005 & .0007 & .0012 & Do. \\
\hline $9702-3 \ldots \ldots$ & 158 & .32 & 1. 65 & & & .26 & None & & .050 & .01 & None & & & .012 & .019 & .019 & .0015 & .0006 & .0005 & .0011 & Do. \\
\hline $9702-4$ & 159 & .31 & 1. 63 & & & .27 & None & & .075 & .02 & None & & & .010 & .020 & .020 & .0015 & .0006 & .0006 & .0012 & Do. \\
\hline $9702-5$ & 160 & .30 & 1.61 & & & .26 & None & & .10 & .03 & None & & & .006 & .020 & .020 & .0015 & .0007 & .0008 & .0015 & Do. \\
\hline $9702-6 \ldots$ & 161 & .31 & 1.64 & & & .26 & None & & .20 & .08 & None & & & .002 & .019 & .019 & .0015 & .0010 & .0000 & .0010 & Do. \\
\hline $10139-1 \ldots$ & 186 & .29 & 1. 56 & .010 & .027 & .17 & None & & None. & -- & None & & & .025 & .023 & .023 & .0015 & .0008 & .0005 & .0013 & Do. \\
\hline $10139-2 \ldots$ & 187 & .30 & 1.56 & & & .18 & None & & 0.10 & .04 & None & & & .010 & .024 & .024 & .0015 & .0010 & .0000 & .0010 & Do. \\
\hline $10139-3 \ldots$ & 188 & .29 & 1.57 & & & .19 & None & & .15 & .07 & None & & & .001 & .023 & .023 & .0015 & .0011 & .0000 & .0011 & Do. \\
\hline $10139-4 \ldots$ & 189 & .29 & 1.57 & & & .18 & None & & .20 & .12 & None & & & .003 & .021 & .021 & .0015 & .0012 & .0000 & .0012 & Do. \\
\hline $10139-5$ & 190 & .27 & 1. 56 & & & .19 & None & & .30 & .15 & None & & .013 & .002 & .017 & .015 & .0015 & .0011 & .0000 & .0011 & Do. \\
\hline $10139-6 \ldots$ & 191 & .26 & 1. 56 & & & .23 & None & & .60 & .36 & None & & -... & .002 & .025 & .025 & .0015 & .0012 & .0000 & .0012 & Do. \\
\hline
\end{tabular}

STEELS WITH HIGH NITROGEN, WITHOUT AND WITH CHROMIUM

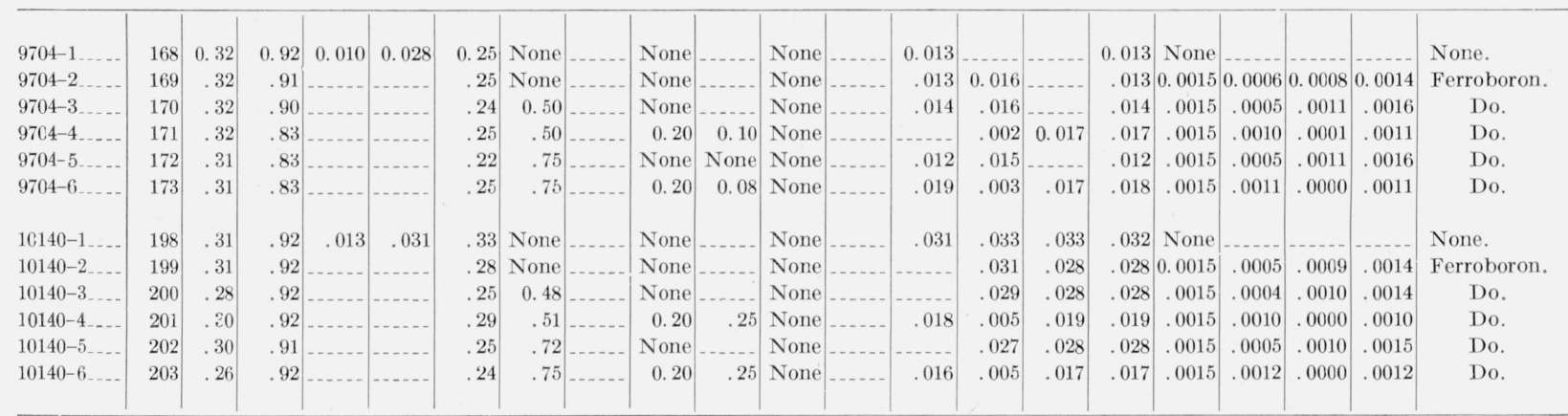

STEELS WITH HIGH NITROGEN, WITHOUT AND WITH ZIRCONIUM

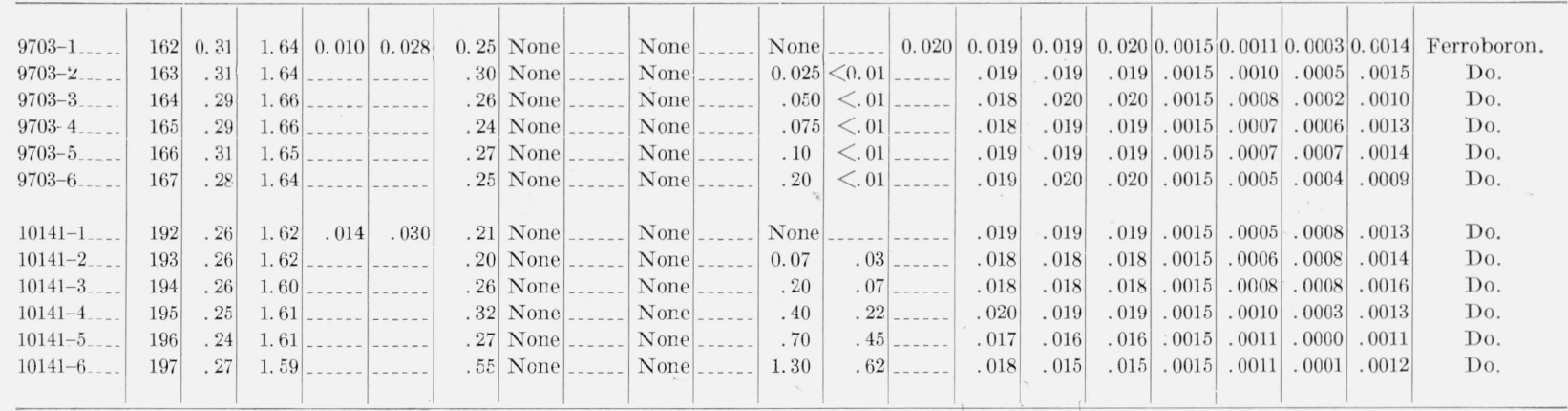

1 Soluble in 1:1 or stronger sulfuric acid.

2 Soluble in 1:1 or stronger sulfuric acid containing approximately $10 \%$ (by volume) of hydrogen peroxide (perhydrol).

3 Two pounds of aluminum per ton $(0.10 \%)$ were added to each heat before making the boron additions as required with ferroboron in the furnace or Grainal No. 79 in the ladle.

${ }^{4} 1: 1$ phosphoric acid. 
TABLE 4.-Chemical composition (percentage by weight) of experimental nickel steels

The chemical composition of steels $17,18,19$, and 20 , without nickel is given in table 1 . These steels are also included in a study of the properties as affected by variation in nickel content.

\begin{tabular}{|c|c|c|c|c|c|c|c|c|c|c|c|}
\hline \multirow{3}{*}{ Heat No. } & \multirow{3}{*}{ Steel No. } & \multirow{3}{*}{$\mathrm{C}$} & \multirow{3}{*}{$\mathrm{Mn}$} & \multirow{3}{*}{$\mathrm{P}$} & \multirow{3}{*}{$\mathrm{S}$} & \multirow{3}{*}{$\mathrm{Si}$} & \multirow{3}{*}{$\mathrm{Ni}$} & \multicolumn{4}{|c|}{ Boron 1} \\
\hline & & & & & & & & \multirow[b]{2}{*}{ Added } & \multicolumn{3}{|c|}{ Recovered } \\
\hline & & & & & & & & & $\begin{array}{c}\text { Acid } \\
\text { soluble } 2\end{array}$ & $\begin{array}{l}\text { Acid } \\
\text { insolu- } \\
\text { ble }^{2}\end{array}$ & Total \\
\hline
\end{tabular}

STEELS WITH $0.35 \%$ NICKEL

\begin{tabular}{|c|c|c|c|c|c|c|c|c|c|c|c|}
\hline $9312-1 \ldots \ldots$ & 98 & 0.30 & 0.83 & 0.014 & 0.031 & 0.25 & 0.35 & None & & & \\
\hline $9312-2 \ldots$ & 99 & .29 & .82 & & - & .27 & .35 & 0.0015 & 0.0007 & 0.0010 & 0.0017 \\
\hline $9312-3 \ldots$ & 100 & .29 & .82 & & & .30 & .35 & .003 & .0014 & .0017 & .0031 \\
\hline $9312-4$ & 101 & .29 & .81 & $\ldots$ & $\ldots$ & .28 & .35 & .006 & .0024 & .0026 & .0050 \\
\hline
\end{tabular}

STEELS WITH $0.6 \%$ NICKEL

\begin{tabular}{|c|c|c|c|c|c|c|c|c|c|c|c|}
\hline $9313-1 \ldots \ldots$ & 102 & 0.30 & 0.85 & 0.011 & 0.028 & 0.28 & 0.56 & None & & & \\
\hline $9313-2 \ldots$ & 103 & .30 & .85 & & & .31 & .56 & 0.0015 & 0.0009 & 0.0008 & 0.0017 \\
\hline $9313-3$ & 104 & .29 & .85 & & & .26 & .56 & .003 & .0017 & .0010 & .0027 \\
\hline $9313-4$ & 105 & .28 & .82 & & & .32 & .56 & .006 & .0030 & .0022 & .0052 \\
\hline
\end{tabular}

STEELS WITH $1.1 \%$ NICKEL

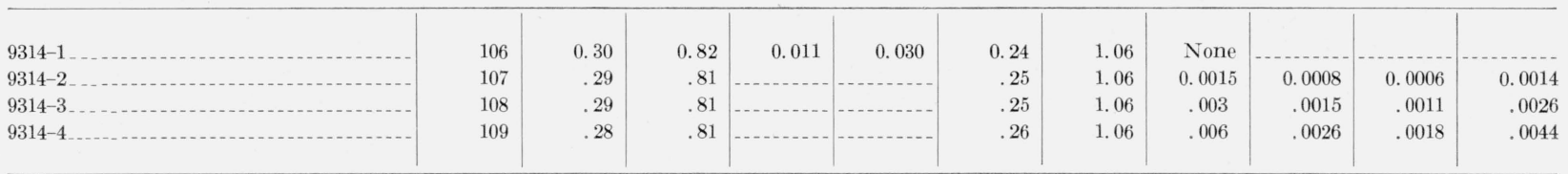

Two pounds of aluminum per ton $(0.10 \%)$ were added to each heat before making the boron additions with Ferroboron as required in the furnace.

2 1:1 phosphoric.

TABLE 5.-Chemical composition (percentage by weight) of experimental chromium steels

The chemical composition of steels $1,2,3,4,13,14,15,16,17,18,19$, and 20 , without chromium is given in table $1 . \quad$ These steels are also included in a study of the properties as affected by variation in chromium content.

\begin{tabular}{|c|c|c|c|c|c|c|c|c|c|c|c|c|c|c|}
\hline \multicolumn{2}{|c|}{ Identification } & \multirow{3}{*}{$\mathrm{C}$} & \multirow{3}{*}{$\mathrm{Mn}$} & \multirow{3}{*}{$\mathrm{P}$} & \multirow{3}{*}{$\mathrm{S}$} & \multirow{3}{*}{$\mathrm{Si}$} & \multirow{3}{*}{$\mathrm{Cr}$} & \multirow{3}{*}{$\mathrm{Ti}$} & \multirow{3}{*}{$\mathrm{N}^{3}$} & \multicolumn{5}{|c|}{ Boron 1} \\
\hline \multirow[b]{2}{*}{ Heat No. } & \multirow{2}{*}{$\begin{array}{l}\text { Steel } \\
\text { No. }\end{array}$} & & & & & & & & & \multicolumn{4}{|c|}{ Recovered } & \multirow[b]{2}{*}{ Ferroalloy } \\
\hline & & & & & & & & & & Added & $\begin{array}{l}\text { Acid } \\
\text { solu- } \\
\text { ble } 2\end{array}$ & $\begin{array}{l}\text { Acid } \\
\text { insol- } \\
\text { uble 2 }\end{array}$ & Total & \\
\hline
\end{tabular}

STEELS WITH $0.8 \%$ Mn AND $0.25 \%$ Cr

\begin{tabular}{|c|c|c|c|c|c|c|c|c|c|c|c|c|c|c|}
\hline $9309-1 \ldots$ & 86 & 0.30 & 0.83 & 0.014 & 0.031 & 0.24 & 0.27 & 0 & & None & & & & None. \\
\hline $9309-2 \ldots$ & 87 & .30 & .84 & & & .26 & .27 & 0 & & 0.0015 & 0.0008 & 0.0010 & 0.0018 & Ferroboron. \\
\hline $9309-3$ & 88 & .29 & .84 & & & .25 & .27 & 0 & & .003 & .0014 & .0015 & .0029 & Do. \\
\hline $9309-4$ & 89 & .28 & .83 & $\ldots$ & -...... & .26 & .27 & 0 & -.. & .006 & .0024 & .0024 & .0048 & Do. \\
\hline
\end{tabular}

STEELS WITH $0.8 \%$ Mn AND $0.50 \%$ Cr

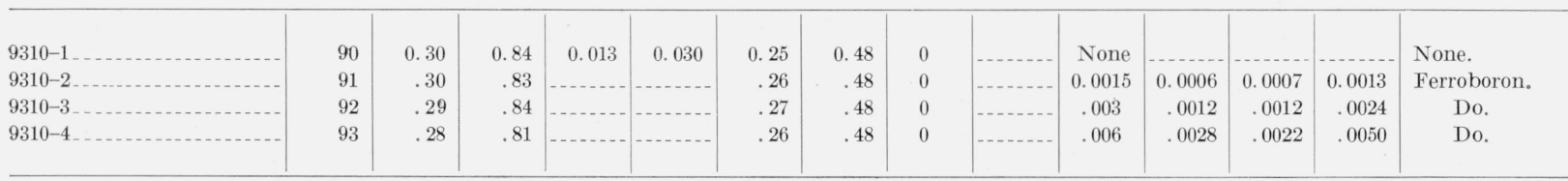

See footnotes at end of table. 
TABLE 6.-Chemical composition (percentage by weight) of experimental nickel-chromium steels

\begin{tabular}{|c|c|c|c|c|c|c|c|c|c|c|c|c|c|c|c|c|c|c|}
\hline \multicolumn{2}{|c|}{ Identification } & \multirow{4}{*}{$\mathrm{C}$} & \multirow{4}{*}{$\mathrm{Mn}$} & \multirow{4}{*}{$\mathrm{P}$} & \multirow{4}{*}{$\mathrm{S}$} & \multirow{4}{*}{$\mathrm{Si}$} & \multirow{4}{*}{$\mathrm{Cr}$} & \multirow{4}{*}{$\mathrm{Ni}$} & \multirow{4}{*}{$\mathrm{Ti}$} & \multirow{4}{*}{$\mathrm{Zr}$} & \multicolumn{2}{|c|}{ Nitrogen 1} & \multicolumn{5}{|c|}{ Boron 4} & \multirow{4}{*}{ Ferroalloy } \\
\hline \multirow{3}{*}{ Heat No. } & \multirow{3}{*}{$\begin{array}{l}\text { Steel } \\
\text { No. }\end{array}$} & & & & & & & & & & \multirow{3}{*}{$\begin{array}{l}\text { Acid } \\
\text { solu- } \\
\text { ble } 2\end{array}$} & \multirow{3}{*}{$\begin{array}{l}\text { To- } \\
\text { tal }^{3}\end{array}$} & & Reco & vered, as & $s$ determ & ined & \\
\hline & & & & & & & & & & & & & & $\mathrm{Ch}$ & emically & & & \\
\hline & & & & & & & & & & & & & & $\begin{array}{l}\text { Acid } \\
\text { solu- } \\
\text { ble } 5\end{array}$ & $\begin{array}{c}\text { Acid } \\
\text { insolu- } \\
\text { ble }^{5}\end{array}$ & Total & $\begin{array}{l}\text { graph- } \\
\text { ically }\end{array}$ & \\
\hline & & & & TEEL & S WIT & ГН 0.8 & $\% \mathrm{Mn}$ & $0.5 \%$ & $\mathrm{Ni}, \mathrm{B}$ & ORON & N ADD & DED V & NITH F & ERROB & ORON & & & \\
\hline 10101-1 & 264 & 0.30 & 0.82 & 0.012 & 0.034 & 0.25 & 0.48 & 0.55 & & & 0.010 & & None & & & & & None. \\
\hline $10101-2$ & 265 & .31 & .81 & & & .26 & .48 & .55 & & $\ldots$ & .011 & & 0.0007 & 0.0004 & 0.0004 & 0.0008 & 0.0007 & Ferroboron. \\
\hline $10101-3$ & 266 & .31 & .81 & & $\mid \ldots \ldots$ & .31 & .50 & .54 & & & .009 & & .0010 & .0004 & .0005 & .0009 & .0008 & Do. \\
\hline $10101-4 \ldots$ & 267 & .31 & .81 & 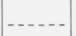 & -..... & .27 & .49 & .55 & & & .008 & & .0015 & .0006 & .0008 & .0014 & .0011 & Do. \\
\hline $10101-5$ & 268 & .29 & .81 & & $\mid \ldots$. & .25 & .49 & .56 & & & .007 & & .003 & .0017 & .0011 & .0028 & .0028 & Do. \\
\hline $10101-6 \ldots$ & 269 & .28 & .79 & $\ldots$ & -.... & .25 & .48 & .55 & & & .007 & & .006 & .0019 & .0034 & .0053 & .0051 & Do. \\
\hline & & & & TEEL & $\mathrm{S}$ WI' & ГН 0.8 & $\% \mathrm{Mr}$ & $1.0 \%$ & $\mathrm{Ni}, \mathrm{B}$ & ORON & $N A D D$ & DED V & WITH F & ERROB & ORON & & & \\
\hline $10102-1$ & 252 & 0.30 & 0.80 & 0.012 & 0.033 & 0.23 & 0.50 & 1.05 & & & 0.009 & & None & & & & & None. \\
\hline $10102-2$ & 253 & .30 & .78 & - & . & .25 & .50 & 1.06 & & & .008 & & 0.0007 & 0.0004 & 0.0006 & 0.0010 & 0.0007 & Ferroboron. \\
\hline $10102-3$ & 254 & .30 & .79 & ...... & $\ldots$ & .23 & .50 & 1.07 & & & .007 & & .0010 & .0005 & .0009 & .0014 & .0008 & Do. \\
\hline $10102-4 \ldots$ & 255 & .29 & .78 & - . & $\ldots$ & .23 & .50 & 1.06 & & & .007 & & .0015 & .0007 & .0011 & .0018 & .0011 & Do. \\
\hline $10102-5 \ldots$ & 256 & .26 & .78 & -... & $\ldots$ & .23 & .50 & 1.05 & & & .007 & & .003 & .0014 & .0017 & .0031 & .0026 & Do. \\
\hline $10102-6 \ldots$ & 257 & .26 & .78 & $\ldots$ & ......... & .22 & .50 & 1. 07 & 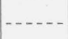 & - & .005 & . & .006 & .0023 & .0027 & .0050 & .0049 & Do. \\
\hline & & & & STEEL & LS WI'] & ГН 0.8 & $\% \mathrm{Mn}$ & $1.0 \%$ & $\mathrm{Ni}, \mathrm{BC}$ & RON & $\mathrm{ADDI}$ & ED W & ITH GR & INAL & NO. 79 & & & \\
\hline $10105-1$ & 270 & 0.31 & 0.84 & 0.019 & 0.028 & 0.28 & 0.51 & 0.89 & & & 0.007 & 0.007 & None & & & & & None. \\
\hline $10105-2$ & 271 & .31 & .87 & & & .27 & .51 & .94 & 0.01 & 0.003 & .003 & .007 & 0.0007 & 0.0002 & 0.0003 & 0.0005 & 0.0005 & Grainal No. 79 . \\
\hline $10105-3 \ldots$ & 272 & .30 & .86 & $\ldots$ & $\ldots$ & .28 & .51 & .94 & .02 & .002 & .002 & .007 & .0010 & .0003 & .0002 & .0005 & .0005 & Do. \\
\hline $10105-4$ & 273 & .30 & .86 & $\ldots$ & $\ldots$ & .30 & .50 & .94 & .03 & .003 & .002 & .006 & .0015 & .0007 & .0001 & .0008 & .0006 & Do. \\
\hline $10105-5 \ldots$ & 274 & .31 & .86 & 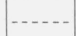 & $\ldots$ & .34 & .50 & .89 & .04 & .008 & .003 & .006 & .003 & .0014 & .0001 & .0015 & .0013 & Do. \\
\hline $10105-6$ & 275 & .30 & .89 & $\ldots$ & $\ldots$ & .30 & .50 & .89 & .09 & .015 & .001 & .005 & .006 & .0026 & .0000 & .0026 & .0032 & Do. \\
\hline & & & & STEEL & LS W & TH 1 & $\% \mathrm{M}$ & $0.5 \%$ & $\mathrm{Ni}, \mathrm{B}$ & ORON & $N$ ADI & DED V & WITH F & RROB & BORON & & & \\
\hline 10103B-1.. & 240 & 0.29 & 1.59 & 0.018 & 0.029 & 0.31 & 0.52 & 0.46 & & & 0.008 & & None & & & & & None. \\
\hline 10103B-2 - & 241 & .30 & 1. 58 & - . - & $\ldots$ & .33 & .51 & .47 & $\ldots$ & -- & .008 & & 0.0007 & 0.0003 & 0.0006 & 0.0009 & 0.0009 & Ferroboron. \\
\hline 10103B-3 ... & 242 & .29 & 1.57 & & & .30 & .52 & .42 & & & .009 & & .0010 & .0003 & .0007 & .0010 & .0008 & Do. \\
\hline 10103B-4 ... & 243 & .28 & 1.57 & $\ldots$ & $\ldots$ & .31 & .51 & .48 & & & .008 & & .0015 & .0003 & .0011 & .0014 & .0015 & Do. \\
\hline $10103 \mathrm{~B}-5 \ldots$ & 244 & .29 & 1. 56 & & & .30 & .51 & .52 & & & .007 & & .003 & .0012 & .0017 & .0029 & .0026 & Do. \\
\hline $10103 B-6$ & 245 & .28 & 1. 56 & $\ldots$ & $\ldots$ & .29 & .50 & .45 & $\ldots . .$. & - & .008 & 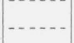 & .006 & .0028 & .0033 & .0061 & .0049 & Do. \\
\hline & & & & STEEL & LS WI' & TH 1. & $\% \mathrm{M}$ & $1.0 \%$ & $\mathrm{Ni}, \mathrm{B}$ & ORON & $N$ ADI & DED V & WITH F & ERROB & $3 O R O N$ & & & \\
\hline $10104-1$ & 246 & 0.31 & 1. 56 & 0.013 & 0.031 & 0.25 & 0.50 & 1.09 & & & 0.010 & & None & & & & & None. \\
\hline $10104-2$ & 247 & .30 & 1.56 & $\ldots$ & & .25 & .50 & 1.09 & & & .008 & & 0.0007 & 0.0004 & 0.0007 & 0.0011 & 0.0007 & Ferroboron. \\
\hline 10104-3 & 248 & .30 & 1. 56 & & & .22 & .50 & 1.09 & & & .008 & & .0010 & .0004 & .0004 & .0008 & .0011 & Do. \\
\hline $10104-4$ & 249 & .30 & 1. 57 & & & .24 & .50 & 1. 08 & & & .009 & & .0015 & .0006 & .0011 & .0017 & .0014 & Do. \\
\hline $10104-5 \ldots$ & 250 & .27 & 1. 55 & & & .28 & .50 & 1. 10 & & & .007 & & .003 & .0010 & .0021 & .0031 & .0030 & Do. \\
\hline $10104-6 \ldots$ & 251 & .27 & 1. 56 & & & .25 & .50 & 1. 09 & & & .007 & & .006 & .0025 & .0038 & .0063 & .0045 & Do. \\
\hline & & & & STEEI & LS W & ТН 1. & $\mathrm{Mr}$ & $1.0 \%$ & $\mathrm{Ni}, \mathrm{BC}$ & ORON & ADDI & ED W & ITH GR & AINAL & NO. 79 & & & \\
\hline $10106-1$ & 276 & 0.29 & 1. 60 & 0.020 & 0.025 & 0.27 & 0.50 & 1.00 & & & 0.008 & 0.007 & None & & & & - . & None. \\
\hline $10106-2$ & 277 & .30 & 1.50 & & & .32 & .50 & .95 & 0.01 & 0.004 & .004 & .007 & 0.0007 & 0.0004 & 0.0001 & 0.0005 & 0.0005 & Grainal No. 79. \\
\hline $10106-3 \ldots$ & 278 & .30 & 1. 61 & & & .27 & .49 & .97 & .02 & .003 & .002 & .006 & .0010 & .0006 & .0000 & .0006 & .0007 & Do. \\
\hline $10106-4 \ldots$ & 279 & .28 & 1.60 & & & .29 & .49 & .97 & .03 & .003 & .002 & .008 & .0015 & .0014 & .0000 & .0014 & .0019 & Do. \\
\hline $10106-5 \ldots$ & 280 & .28 & 1. 60 & & & .30 & .50 & .95 & .06 & .014 & .001 & .008 & .003 & .0018 & .0000 & .0018 & .0019 & Do. \\
\hline $10106-6 \ldots$ & 281 & .28 & 1. 65 & & & .30 & .50 & .97 & .10 & .018 & .002 & .007 & .006 & .0030 & .0000 & 0030 & .0035 & Do. \\
\hline
\end{tabular}

1 Determinations were made by a modified Allen method.

2 Soluble in 1:1 or stronger sulfuric acid.

3 Soluble in 1:1 or stronger sulfuric acid containing approximately 10 percent (by volume) hydrogen peroxide (perhydrol).

${ }^{4} 2 \mathrm{lb}$. of aluminum per ton were added to each heat before making the boron additions with Ferroboron or Grainal No. 79 as required in the furnace.

${ }_{5}$ 1:1 phosphoric acid. 
TABLE 7.-Chemical composition (percentage by weight) of experimental chromium-molybdenum steels-Continued

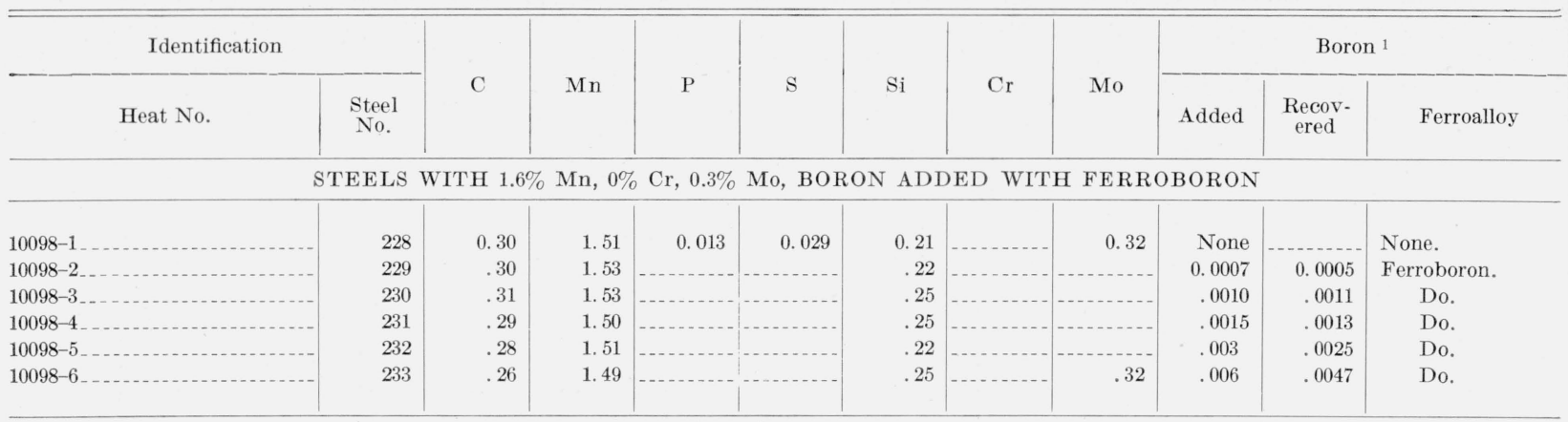

STEELS WITH $1.6 \% \mathrm{Mn}, 0.75 \% \mathrm{Cr}, 0.15 \%$ Mo, BORON ADDED WITH FERROBORON

\begin{tabular}{|c|c|c|c|c|c|c|c|c|c|c|c|}
\hline $10097-1$ & 210 & 0.30 & 1. 53 & 0.013 & 0.032 & 0.26 & 0.74 & 0.17 & None & & None. \\
\hline $10097-2 \ldots$ & 211 & .29 & 1.50 & & & .29 & .74 & ..... & 0.0007 & 0.0006 & Ferroboron. \\
\hline $10097-3 \ldots$ & 212 & .28 & 1.48 & & & .29 & .74 & & .0010 & .0009 & Do. \\
\hline $10097-4$ & 213 & .28 & 1. 49 & & & .31 & .73 & . & .0015 & .0012 & Do. \\
\hline $10097-5$ & 214 & .28 & 1. 47 & & & .28 & .75 & -... & .003 & .0024 & Do. \\
\hline $10097-6 \ldots$ & 215 & .26 & 1.48 & & & .27 & .73 & .17 & .006 & .0043 & Do. \\
\hline
\end{tabular}

$12 \mathrm{lb}$ of aluminum per ton were added to each heat before making the boron additions with Ferroboron or Grainal No. 79 as required in the furnace. Deter minations for boron were made by spectrographic analysis.

TABLE 8.-Chemical composition (percentage by weight) of the commercial steels

Determinations for carbon, manganese, phosphorus, sulfur, silicon, nickel, chromium, molybdenum, and copper were made at Buick Motor Division, General Motors Corporation, and vanadium, titanium, zirconium, and aluminum at Battelle Memorial Institute. Determinations for nitrogen by a modified Allen method and boron by chemical and spectrographic analyses were made at the National Bureau of Standards. All samples for chemical analysis were prepared from Bar Nc. 1 of each steel as hot-rolled by milling the entire cross section after turning $1 / 8$ in. from the diameter of the $11 / 4$-in. rounds. The specimens for spectrographic analysis were $7 / 32$-in. rounds prepared with the center at half-radius of the $11 / 4$-in. rounds (Bar No. 1) of the steels with boron additions of 0.001 percent or greater and $11 / 8$-in. disks $(3 / 8$ in. to $1 / 2$ in. thick) of the steels with boron additions less than 0.001 percent.

\begin{tabular}{|c|c|c|c|c|c|c|c|c|c|c|c|c|c|c|c|c|c|c|c|c|c|}
\hline \multirow{4}{*}{ Steel No. } & \multirow{4}{*}{$\mathrm{C}$} & \multirow{4}{*}{ Mn } & \multirow{4}{*}{$\mathrm{P}$} & \multirow{4}{*}{$\mathrm{S}$} & \multirow{4}{*}{$\mathrm{Si}$} & \multirow{4}{*}{$\mathrm{Ni}$} & \multirow{4}{*}{$\mathrm{Cr}$} & \multirow{4}{*}{ Mo } & \multirow{4}{*}{ V } & \multirow{4}{*}{$\mathrm{Ti}$} & \multirow{4}{*}{$\mathrm{Zr}$} & \multirow{4}{*}{$\mathrm{Cu}$} & \multirow{4}{*}{$\begin{array}{l}\mathrm{Al} \\
\text { (to- } \\
\text { tal) }\end{array}$} & \multicolumn{2}{|c|}{ Nitrogen } & \multicolumn{5}{|c|}{ Boron } & \multirow{4}{*}{ Ferroalloy } \\
\hline & & & & & & & & & & & & & & \multirow{3}{*}{$\begin{array}{l}\text { Acid } \\
\text { solu- } \\
\text { ble } 1\end{array}$} & \multirow{3}{*}{$\begin{array}{c}\text { To- } \\
\text { tal }^{2}\end{array}$} & \multirow{3}{*}{$\begin{array}{c}\text { Add- } \\
\text { ed }\end{array}$} & \multicolumn{4}{|c|}{ Recovered, as determined } & \\
\hline & & & & & & & & & & & & & & & & & \multicolumn{3}{|c|}{ Chemically } & \multirow{2}{*}{$\begin{array}{c}\text { Spec } \\
\text { tro- } \\
\text { graph- } \\
\text { ically }\end{array}$} & \\
\hline & & & & & & & & & & & & & & & & & $\begin{array}{l}\text { Acid } \\
\text { solu- } \\
\text { ble }^{3}\end{array}$ & $\begin{array}{c}\text { Acid } \\
\text { insol- } \\
\text { uble }{ }^{3}\end{array}$ & Total & & \\
\hline C6.. & 0.44 & 1.58 & 0.017 & 0.019 & 0.40 & 0.01 & 0.05 & 0.01 & Nil & 0.0190 & 0.004 & 0.02 & 0.040 & 0.003 & 0.003 & 0.0011 & 0.0009 & 0.0000 & 0.0009 & 0.0013 & Sileaz No. 3. \\
\hline $\mathrm{C} 7$. & .43 & 1. 59 & .018 & .016 & .45 & .01 & .05 & .01 & Do. & .027 & .005 & .02 & .050 & .003 & .004 & .0015 & .0016 & .0000 & .0016 & .0017 & Do. \\
\hline $\mathrm{C} 8 \ldots$ & .43 & 1.58 & .019 & .019 & .50 & .01 & .05 & .01 & Do. & .053 & .010 & .02 & .058 & .003 & .003 & .0022 & .0031 & .0000 & .0031 & .0042 & Do. \\
\hline $\mathrm{C} 9 \ldots$ & .43 & 1. 58 & .019 & .019 & .32 & .01 & .05 & .01 & Do. & .020 & .004 & .02 & .030 & .002 & .004 & .0006 & .0003 & .0000 & .0003 & .0004 & Grainal No. 79. \\
\hline $\mathrm{C} 10 \ldots$ & .42 & 1. 60 & .019 & .018 & .32 & .01 & .05 & .01 & Do. & .030 & .006 & .02 & .047 & .002 & .003 & .0013 & .0006 & .0000 & .0005 & .0009 & Do. \\
\hline C11 _. & .42 & 1. 59 & .019 & .018 & $.3 \%$ & .01 & .05 & .01 & Nil & .052 & .007 & .02 & .053 & .002 & .003 & .0019 & .0011 & .0000 & .0011 & .0014 & Do. \\
\hline $\mathrm{C} 1{ }^{\prime}$ & .43 & 1. 56 & .020 & .019 & .31 & .01 & .05 & .01 & Do. & .001 & .002 & .02 & .049 & .004 & .005 & .0020 & .0009 & .0013 & .0022 & .0020 & Ferroboron. \\
\hline $\mathrm{C} 13$. & .43 & 1. 58 & .020 & .017 & .31 & .01 & .05 & .01 & Do. & .001 & .002 & .02 & .045 & .004 & .004 & .0030 & .0017 & .0011 & .0028 & .0028 & Do. \\
\hline C14_... & .43 & 1. 59 & .018 & .019 & .32 & .01 & .05 & .01 & Do. & .001 & .002 & .02 & .042 & .002 & .005 & .0040 & .0026 & .0010 & .0036 & .0040 & Do. \\
\hline $\mathrm{C} 15 \ldots$ & .43 & 1. 58 & .020 & .019 & .31 & .01 & .05 & .01 & Do. & .001 & .002 & .02 & .025 & .004 & .004 & None & .0000 & $<.0001$ & $<.0001$ & $\ldots$ & None. \\
\hline $\mathrm{C} 16$ & .42 & 1. 59 & .019 & .021 & .33 & .01 & .04 & .01 & $<0.004$ & .005 & .004 & .02 & .047 & .002 & .003 & .0013 & .0012 & .0000 & .0012 & .0014 & Bortam. \\
\hline $\mathrm{C} 17_{-}$ & .43 & 1. 62 & .019 & .019 & .35 & .01 & .04 & .01 & $<.004$ & .013 & .004 & .02 & .054 & .002 & .004 & .0027 & .0025 & .0000 & .0025 & .0029 & Do. \\
\hline C18... & .43 & 1. 64 & .020 & .019 & .37 & .01 & .04 & .01 & $<.004$ & .030 & .005 & .02 & .069 & .002 & .003 & .0040 & .0038 & .0000 & .0038 & .0046 & Do. \\
\hline C19... & .43 & 1. 58 & .019 & .018 & .31 & .01 & .04 & .01 & .015 & .004 & .003 & .02 & .040 & .002 & .005 & .0004 & .0001 & .0000 & .0001 & .0003 & Grainal No. 1. \\
\hline $\mathrm{C} 20 \ldots$ & .43 & 1. 58 & .019 & .020 & .31 & .01 & .04 & .01 & .027 & .015 & .002 & .02 & .045 & .002 & .004 & .0008 & .0003 & .0001 & .0004 & .0004 & Do. \\
\hline $\mathrm{C} 21 \ldots$ & .42 & 1.57 & .019 & .020 & .32 & .01 & .04 & .01 & .070 & .020 & .003 & .02 & .054 & .002 & .005 & .0011 & .0006 & .0000 & .0006 & .0006 & Do. \\
\hline $\mathrm{C} 22$ & .43 & 1. 57 & .019 & .021 & .35 & .01 & .05 & .01 & .004 & .005 & .003 & .02 & .031 & .003 & .005 & .0005 & .0004 & .0003 & .0007 & .0005 & Silvaz No. 3. \\
\hline $\mathrm{C} 23 \ldots$ & .43 & 1. 57 & .021 & .020 & .35 & .01 & .04 & .01 & .020 & .012 & .005 & .02 & .046 & .004 & .005 & .0010 & .0008 & .0000 & .0008 & .0012 & Do. \\
\hline $\mathrm{C} 24 \ldots$ & .43 & 1. 57 & .019 & .019 & .42 & .01 & .05 & .01 & .025 & .015 & .010 & .02 & .045 & .003 & .005 & .0016 & .0011 & .0000 & .0011 & .0016 & Do. \\
\hline $\mathrm{C} 25_{\ldots} \ldots$ & .43 & 1. 57 & .019 & .021 & .34 & .01 & .05 & .01 & $<.004$ & .001 & .002 & .02 & .048 & .004 & .005 & .0019 & .0007 & .0009 & .0016 & .0015 & Borosil. \\
\hline C26.... & .43 & 1. 57 & .021 & .020 & .36 & .01 & .04 & .01 & $<.004$ & Nil & .002 & .02 & .046 & .004 & .004 & .0036 & .0015 & .0011 & .0026 & .0027 & Do. \\
\hline $\mathrm{C} 4145 \ldots$ & .43 & .95 & .017 & .019 & .21 & .09 & .92 & .20 & Nil & .001 & .002 & .05 & .038 & .008 & .007 & None & .0000 & .0000 & .0000 & - & None. \\
\hline
\end{tabular}

1 Soluble in $1: 1$ or stronger sulfuric acid.

2 Soluble in $1: 1$ or stronger sulfuric acid containing approximately 10 percent (by volume) hydrogen peroxide (perhydrol).

${ }^{3} 1: 1$ phosphoric acid. 
Except for boron and nitrogen, the values for the various elements given in the tables for the experimental steels were obtained at the Battelle Memorial Institute on drillings from the ingot at the base of the hot top (fig. 1,A), whereas the values for the commercial steels were obtained in the above laboratory or at Buick Motor Division, General Motors Corp. on specimens prepared from 11/4-in. rounds as hot-rolled. For the experimental steels, the phosphorus and sulfur contents were determined only on one ingot from each of the heats and the molybdenum content of the chromium-molybdenum steels (table 7) was usually determined on the first and last ingot prepared from the heat.

Determinations for nitrogen and boron were made at the National Bureau of Standards on samples of the experimental steels prepared from the $1 / 2$-in. plates as hot-rolled or as hot-rolled and heat-treated (fig. 1,B, section B) and on samples prepared from $1 \frac{1}{4}$-in. rounds of the commercial steels as hot-rolled.

The nitrogen content of some of the steels was determined by both the vacuum fusion and modified Allen methods (table 3). As the values obtained by the two methods agreed closely, the more rapid and convenient Allen (modified) method was used for making a majority of the determinations for this element.

At the start of the investigation, the boron content of the steels was determined by dissolving the sample in hydrochloric acid, distilling the boron as methyl borate, and titrating with standard alkali. Values obtained by this method agreed closely with those obtained by a distillation-colorimetric method using phosphoric acid and turmeric. The latter method was used for determining most of the values given in the tables. The concentration of boron was also determined in some of the experimental and all the commercial steels treated with boron by comparing the arc spectra of a specimen of the steel with the spectra of standards. The procedure used for determining boron spectrographically is described in detail in another report [13] but those used for determining boron chemically [14] and nitrogen by a modified Allen method [15] have not been published. The amounts of boron added and recovered are given in tables 1 to 8 . However,
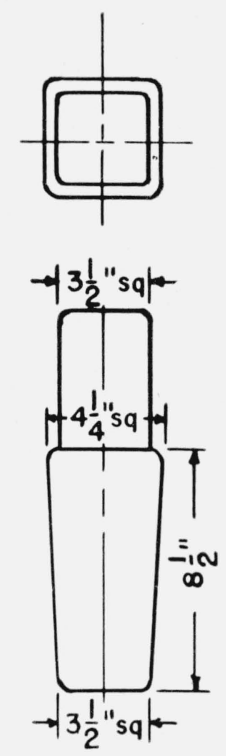

A
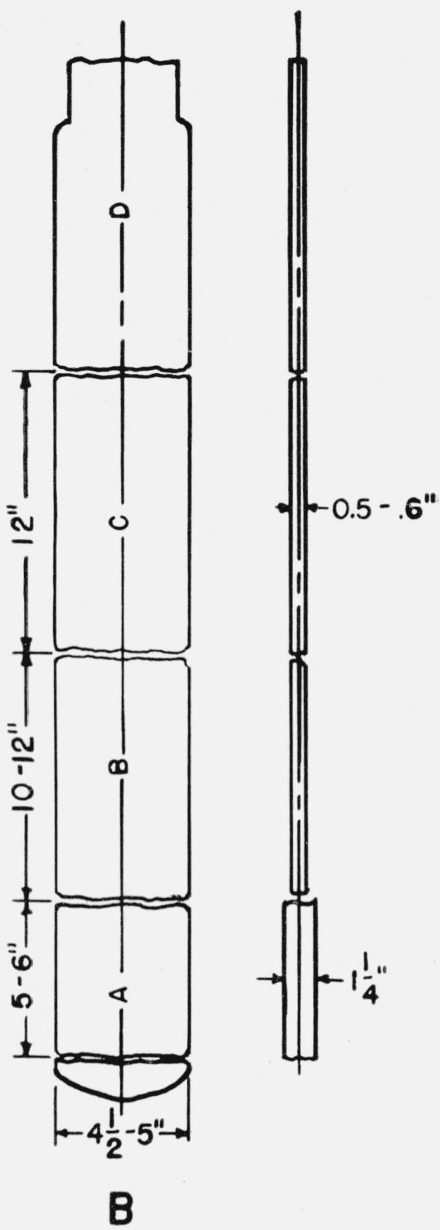

FIGURE 1.-Forms and dimension of ingots and hot-rolled plates of experimental steels.

unless otherwise stated, the amount retained is used as a basis for making comparisons throughout the text.

\section{Preparation}

(a) Experimental

The experimental steels were made in a magnesia-lined induction furnace at the Battelle Memorial Institute. The general practice was to use ingot iron as the base material; to melt without a protecting slag; and to make all additions in the furnace. All of the iron (200 to $325 \mathrm{lb}$ ) with small amounts of ferrosilicon and ferromanganese were included in the initial charge. Additions of ferromanganese, ferrosilicon, siliconmanganese alloy, graphite, and $2 \mathrm{lb}$ of aluminum per ton $(0.10 \%)$ were made just prior to pouring: 
the first in a series of either four or six ingots each weighing about 50 lbs. Boron additions were made in the furnace, with ferroalloys of the type composition given in table 9 , at the required intervals during pouring in order to produce ingots from each heat varying primarily in boron content. The metal was poured directly into big-end-up steel molds equipped with hot-tops (fig. 1, A). Usually, it required about 2 minutes to make the boron additions and to pour the heat (in some cases, about 5 minutes), and the temperature of the metal at the time of pouring as determined with an optical pyrometer for some of the heats ranged from about $2,800^{\circ}$ to $3,050^{\circ} \mathrm{F}$.

TABLE 9.-Chemical composition of the ferroalloys used for the boron additions

\begin{tabular}{l|c|c|c|c|c|c|c|c|c|c}
\hline \hline \multirow{2}{*}{ Designation } & \multicolumn{6}{|c}{ Composition, percent by weight } \\
\cline { 2 - 4 } & $\mathrm{C}$ & $\mathrm{Mn}$ & $\mathrm{Si}$ & $\mathrm{Ti}$ & $\mathrm{Zr}$ & $\mathrm{Al}$ & $\mathrm{Cu}$ & $\mathrm{Ca}$ & $\mathrm{B}$ & $\mathrm{V}$ \\
\hline
\end{tabular}

EXPERIMENTAL STEELS

\begin{tabular}{|c|c|c|c|c|c|c|c|c|c|}
\hline Ferroboron_. & & & & & $\ldots$ & . & $\ldots$ & & 12.1 \\
\hline Grainal No. $79 \ldots$ & 0.05 & 7.5 & 3.4 & 19.6 & 3.6 & 13. 0 & 1. 7 & & 0.54 \\
\hline Synthetic mixture ${ }^{1}$ & ...... & - & & & - & & & & \\
\hline Silcaz No. $3 \ldots$ & $\ldots$ & 0.4 & 37.66 & 9.39 & 3. 88 & 7. 16 & $\ldots$ & 9.76 & .55 \\
\hline
\end{tabular}

COMMERCIAL STEELS

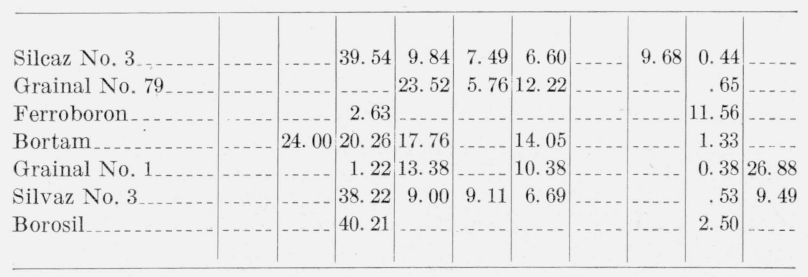

1 This synthetic mixture, with composition similar to Grainal No. 79, was prepared with ferroboron, ferromanganese, ferrotitanium, zirconium-aluminum, aluminum, and copper.

Except for four heats (9702, 10139, 9703, and 10141, table 3) prepared to determine the effects of titanium or zirconium on the properties of high nitrogen steels containing about 0.0015 percent of boron, an ingot without boron was prepared from each heat for use as a basis for comparing the properties of the steels comprising the heat. This was considered essential because of the wide variation in hardenability often observed in steels that are nearly alike chemically.

The general practice, however, was modified in preparing the steels used for studying the effect of nitrogen content and the deoxidation practice on the properties of boron-treated steels, and for determining the amounts of boron recovered after remelting. In preparing some of the steels with variable nitrogen (heats 9079, 9080, and 9081, table 3 ) the charge was melted under an atmosphere of natural gas and sufficient slag was added to the molten bath to insure complete coverage; the flow of gas over the bath was stopped, and calcium cyanamide was added before removing the slag and deoxidizing with aluminum in the usual manner. Additions of aluminum ranging from 0 to $2 \mathrm{lb}$ per ton were used in the heats (8889, table 1 and 9089, 9090, 9361, 9450, 9362, and 9360 , table 2) prepared to study deoxidizing practice. Some of the steels used to determine the recovery of boron on remelting were prepared by the usual melting practice, whereas mill scale was added to other heats as described in some detail in table 14 .

All the ingots, except those used for determining the recovery of boron on remelting, were rolled at the Bureau in the temperature range from about $2,050^{\circ}$ to $1,600^{\circ} \mathrm{F}$ into plates $1 \frac{1}{4}$ in. thick (fig. 1, B, section A) and a portion of each plate was further reduced to a final thickness of 0.5 to 0.6 in. (fig. $1, \mathrm{~B}$, sections $\mathrm{B}, \mathrm{C}$, and $\mathrm{D}$ ). These plates were cooled from the finishing temperature in air. No difficulty was encountered in hot-rolling any of the steels.

\section{(b) Commercial}

The commercial steels were from a Special Addition Agent Heat prepared at the Duquesne Works, Carnegie-Il'inois Steel Corp. for the Ordnance Department, United States Army. The procedure for processing this basic open-hearth heat is given in some detail in a report [16] prepared by the producer for the purchaser. Essentially, the procedure for making the boron additions consisted in adding in the mold one of the ferroalloys, listed in table 9, at regular intervals throughout the pouring of the ingot, starting after pouring 6 to $8 \mathrm{in}$. of metal and continuing up to the base of the hot-top. Thirty-two ingots (each 22 by 25 in., 8,600 lb) were prepared from this heat and the steels selected for use in the present investigation (C6 to $\mathrm{C} 26$ ) are listed in table 8 in the order of pouring. The fifteenth ingot (C15) was prepared without boron in order to have the base steel from near the middle of the pour. Each ingot was hot-rolled and cut into six pieces 5.5 by 5.5 in. by $10 \mathrm{ft}$ and the bottom-center was further 
the direction of rolling from the $1 / 2$-in. plates as hot-rolled of all the experimental steels (fig. 1, B, section $\mathrm{B}$ ). The inclusions were mainly manganese sulfide (elongated by rolling), with a few silicates and oxides in the base steels either not deoxidized or deoxidized with aluminum (fig. 2, A) and in the Ferroboron-treated steels containing high or low nitrogen (fig. 2, B). Variations in the deoxidation practice and composition of the ferroalloys used for making the boron additions had no appreciable influence on the cleanliness except for the presence of titanium and zirconium inclusions (nitrides) in the steels treated with ferroalloys containing these elements. The number, form, size and distribution of the inclusions were similar in the steels when treated with Grainal No. 79 (fig. 2, C) or Silcaz No. 3 for the same boron content.

The number of nitride inclusions usually increased with amounts of retained titanium or zirconium. In the steels with relatively high proportion of either of these elements, the nitride inclusions were often coalesced in streaks, as is illustrated for a commercial steel in the typical photomicrographs of figure 2, F. However, no boron inclusions were identified in any of these steels as hot-rolled. All the steels were considered as being relatively clean and representative of good steel-making practice.

Although all of the experimentalsteels had satisfactory hot-working properties, considerable variations were observed in the degree of ferrite banding and in the amounts of free ferrite in the structures of the $1 / 2$-in. thick plates as hot-rolled and as normalized. The amount of ferrite banding and of proeutectoid ferrite (free ferrite) in hypoeutectoid steels will vary with the chemical composition of the steels and the rate of cooling through the transformation temperature range. As the rate of cooling from the normalizing temperature was of the same order of magnitude in the $1 / 2$-in. plates (normalizing temperature was $1,650^{\circ} \mathrm{F}$ for all steels except that $1,575^{\circ} \mathrm{F}$ was used for the four steels containing 0.45 percent carbon and $1,675^{\circ} \mathrm{F}$ for the steels comprising the nickelchromium and chromium-molybdenum series), ar indication of the effect of boron additions with the various ferroalloys on the ferrite banding and amount of free ferrite may be obtained by a comparison of these structures. Obviously, the comparisons are valid only for the range in cooling rates used; not for markedly different rates. The general trend was for the ferrite banding and amount of free ferrite in the structures of the plates normalized at $1,650 \mathrm{~F}$ to be decreased by the addition of boron in the plain carbon-manganese steels and in similar steels with additions of either nickel or chromium as is illustrated in the typical photomicrographs of figure $3, \mathrm{~A}$ and $\mathrm{B}$. However, the data obtained with these steels clearly indicate that variations in composition of ferroalloys, amount of boron retained, and in deoxidation practice affected these factors primarily through their influence on the grain size at the normalizing temperature $\left(1,650^{\circ} \mathrm{F}\right)$. Appreciable banding usually occurred in the finegrained steels (fig. 3, A and C), whereas the coarse-grain steels (regardless of how produced) were relatively free from streaks of ferrite (fig. 3, $\mathrm{B}$ and $\mathrm{D})$.

Some banding was observed in the structures of plates of all the nickel-chromium steels normalized at $1,675^{\circ} \mathrm{F}$. These steels were also fine-grained at the temperature used in normalizing. It should be pointed out, however, that all the finegrained steels of hypoeuctoid composition, such as those containing chromium-molybdenum and 0.8 percent of manganese with and without boron, did not show ferrite banding in structures produced by normalizing relatively thin sections.

The structures of the aormalized plates consisted of ferrite and pearlite (fig. 3, E) in most of the steels and pearlite and bainite in a few of the relatively deep-hardening steels. The specimens subsequently used for test purposes were prepared from the plates as normalized.

\section{(b) Commercial}

A section was prepared from a 1/1/4-in. round bar of each of the commercial steels for rating of the inclusion by microscopic methods. This section was hardened, and a longitudinal face extending from the surface to the center of the original bar (fig. 4, A, shaded area) was polished for microscopic examination. No significant difference was observed in the type or distribution of the inclusions from surface to center of the $1 \frac{1}{4}-$ in. rounds.

The number, size, type, and distribution of inclusions observed are illustrated in typical 

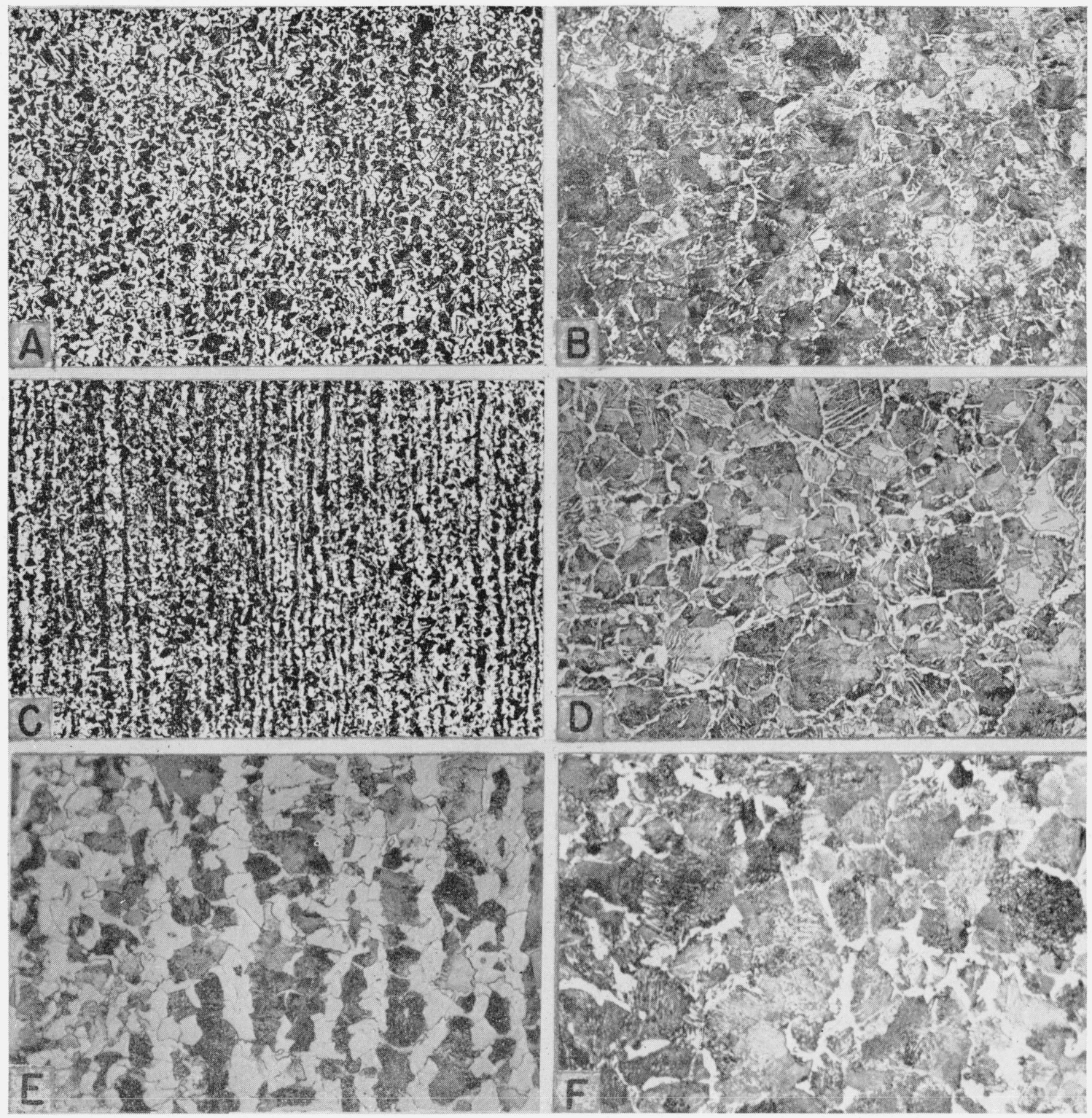

FiguRE 3.- Structure of experimental and commercial steels as normalized at $1,650^{\circ} \mathrm{F}$.

Etched with $1 \%$ nital. A, B, C, and D, $\times 100 ; \mathrm{E}$, and $\mathrm{F}, \times 500$.

Boron

Figure

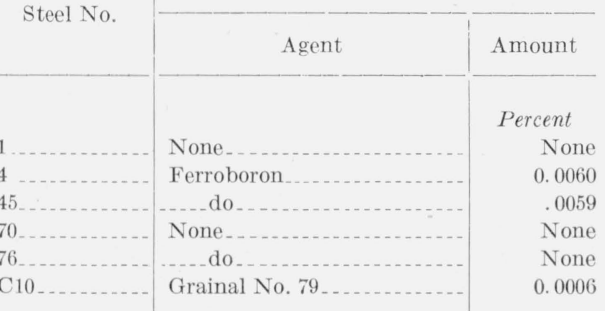

Boron-Treated Steels

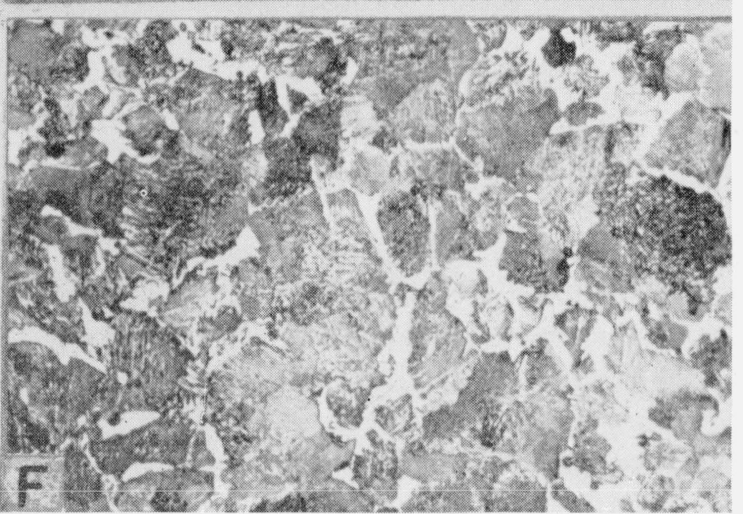




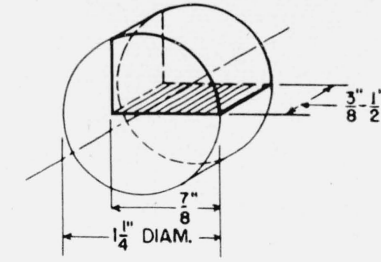

A. INCLUSION RATING

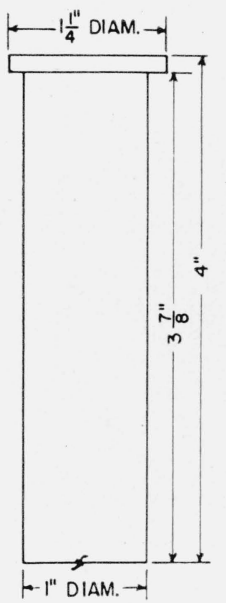

C. JOMINY

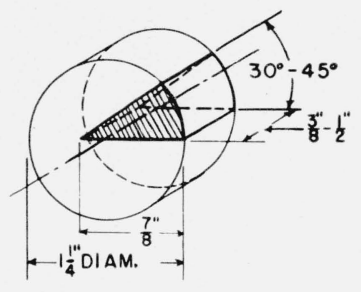

B. GRAIN SIZE

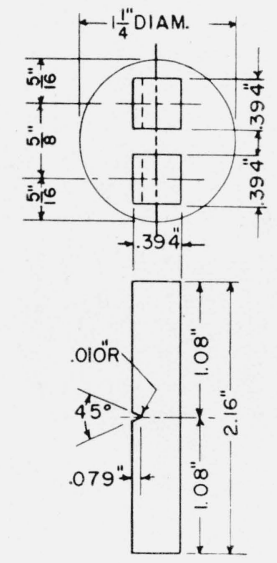

D. IMPACT
FIguRE 4.-Forms and dimensions of some of the test specimens.

amount of the addition. These inclusions were sometimes segregated in streaks (fig. 2, F), however, they usually were fairly uniformly distributed (fig. 2, D). Except for the presence of the titanium inclusions, all the steels were considered to be clean.

The structures produced in the $1 \frac{1}{4}$-in. rounds of the commercial steels of the Special Addition Agent Heat (steels C6 to C26) by normalizing at $1,650^{\circ} \mathrm{F}$ consisted of proeutectoid ferrite in a matrix of pearlite varying to some extent in degrees of fineness. The ferrite was uniformly distributed principally in the parent austenite boundaries (fig. 3, F), with no material difference in structure from surface to center of the bars.

The specimens subsequently used for test purposes, which were prepared from the normalized bars, had initial structures similar to that shown in figure 3, F. These steels, as normalized, were practically free from banding (a slight band- ing was observed in a longitudinal section of C15, without boron), although a pattern effect of the original ingot was observed in each steel.

\section{Testing Procedure}

The general procedures, as described below, were regularly followed in preparing, heat-treating and testing specimens used in the determination of the temperatures of transformations, grain sizes, hardenability, notch toughness and tensile properties of the steels. An attempt has been made to record, in the text, all important departures from these procedures and other essential details necessary for clarity.

\section{Transformations}

The temperatures of the transformations $\left(A_{1}\right.$ and $A_{3}$ ) in specimens heated or cooled relatively slowly were obtained with a linear expansion apparatus (dilatometer) of fused quartz, mechanical dial indicator, Chromel-Alumel thermocouple, and precision potentiometer. However, these tests made on two steels (1 and 4) were supplemented by determinations made with a precision micrometric thermal-expansion apparatus in which the specimens were heated and cooled at considerably slower rates.

Small specimens (approximately 0.15 in. square by $0.04 \mathrm{in}$. thick) were used in determing the temperature of the $A r^{\prime \prime}$ transformation (austenite to martensite). These specimens were heated in vacuum or dry nitrogen to the quenching temperature, held at this temperature for 15 minutes, and then quenched directly in helium at room temperature. Photographic time-temperature cooling curves were obtained during the quench by means of a string galvanometer apparatus. The procedures for preparing the specimens, heating and quenching and obtaining the cooling curves were essentially the same as those previously described in some detail [17].

\section{Heat Treatment}

An electric furnace of the muffle type with atmosphere control was used for all normalizing, annealing, and hardening operations, and electric furnaces with forced circulation were used for tempering. Each furnace was equipped with an automatic control and an indicating or recording 
pyrometer. The temperatures of many of the operations were also checked and obtained by means of a Chromel-Alumel thermocouple and a precision potentiometer. Except for the McQuaid-Ehn test, the furnaces were at the desired temperatures when the specimens were inserted, and the timing of the operation was started at this point with the specimens prepared from the experimental steels. However, this procedure was modified with the commercial steels in that the actual time required for the specimens to reach the temperature of the furnace was not included in the measurement of time. A reducing atmosphere was used for all normalizing, annealing, and hardening treatments.

\section{Austenite and McQuaid-Ehn Grain Sizes}

Determinations were made of the grain sizes established at temperatures ranging from those used in hardening $\left(1,475^{\circ}\right.$ to $\left.1,600^{\circ} \mathrm{F}\right)$ to $1,900^{\circ} \mathrm{F}$. Small specimens, prepared from initially normalized plates (fig. 1, B, section B) or bars (fig. 4, B), were heated in a furnace at these temperatures for 30 minutes (commercial steel) or 45 minutes (experimental steels) and then cooled in a manner suitable for delineating the austenite grains. (The grain size at the temperatures used for normalizing the experimental steels was determined from the normalized plates. The initial condition, therefore, was as hot-rolled, and the time in the furnace was 60 minutes.) The crosssections of the specimens were polished and then etched with nital preparatory to estimating the grain size by comparing the microscopic image at 100 diameters with an American Society for Testing Materials standard grain size chart prepared on the ground-glass fixture of the camera extension of the microscope.

Similar specimens prepared from each steel were packed in a commercial carburizer, heated with the furnace to $1,700^{\circ} \mathrm{F}$, held at this temperature for $8 \mathrm{hr}$, and then cooled with the furnace or in the carburizing box in air (McQuaid-Ehn test). The polished specimens were either etched in nital or boiling sodium picrate prior to estimating the grain size of the case and core by comparing with the American Society for Testing Materials chart. In some cases the grain size measurements were made on two or more specimens, but the usual procedure was to use only one specimen for each condition when the grains were clearly delineated in that specimen.

In many of the steels considerable difficulty was encountered in clearly delineating the parent austenite grains with proeutectoid ferrite. In numerous cases, acicular ferrite was formed not only in the prior austenite boundaries but also in the interior of the grains, and pronounced banding of ferrite was often obtained in the final structure by following the usual procedure for outlining austenite grains in a hypoeutectoid steel. Excessive banding of ferrite during the course of this treatment was especially noticeable in the deep-hardening steels, and this banding is a factor that must be considered as a possibility of influencing the accuracy of the observations.

\section{Hardenability}

An end-quench (Jominy) test was made on a specimen prepared from each steel. With the experimental steels, oversize specimens were prepared from the 1/1/4-in. thick plates as hot-rolled in such a manner that the water-cooled end of each specimen was from the same relative position (fig. $1, \mathrm{~B}$, section $\mathrm{A}$, with water-cooled end adjacent to section $\mathrm{B}$ ) of the original ingot. These specimens were then normalized prior to finishing to size (fig. 4, C). With the commercial steels, the specimens (fig. 4, C) were prepared from 1/1/4-in. rounds after normalizing. The specimens were placed vertically on the end to be water-cooled in a furnace with a slightly reducing atmosphere at the hardening temperature, held in the furnace for 45 minutes before cooling in a fixture in accordance with the procedure recommended by the American Society for Testing Materials [18]. Two flat surfaces were wet-ground 180 degrees apart along the length of the quenched specimen, and Rockwell "C" hardness measurements were made along the center line of each of these flat surfaces at intervals of $1 / 16$ in. for the required distance from the quenched end. The procedure was to grind the quenched bar to a depth of $0.015 \mathrm{in}$., except those quenched from high temperatures were ground to a depth of 0.030 to $0.045 \mathrm{in}$. A special fixture for holding the specimen was constructed and calibrated to expedite testing and to insure accuracy. 


\section{Notch Toughness}

Charpy impact tests were made with quenched and tempered specimens of the form and dimensions shown in figure $4, \mathrm{D}$ and figure 5.

The manner of preparing the specimens of the experimental steels from normalized $1 / 2-i$. thick plates and of the commercial steels from normalized $1 \frac{1}{4}-\mathrm{in}$. rounds is also illustrated in figures 5 and 4 , D respectively. All specimens were roughmachined to 0.41 to $0.45 \mathrm{in}$. square by about 2.16 in. long, heat-treated and then finished by wet grinding to size (ends not ground), and notched. The notch was located at right angles to the direction of rolling in the experimental steels (fig. 5), whereas in the commercial steels, the

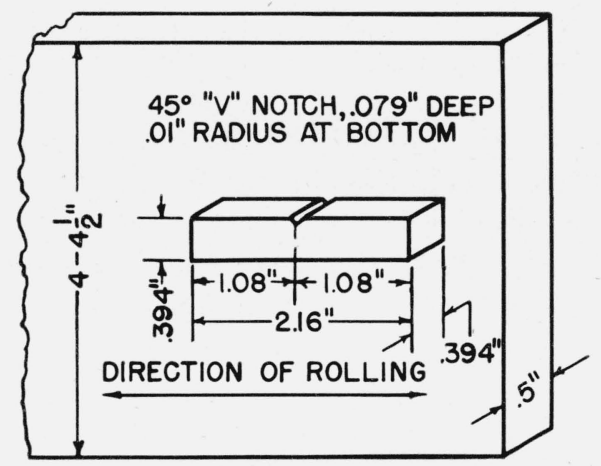

FIGURE 5.-Location of Charpy specimens in relation to the direction of rolling the experimental steels.

notch was located parallel to the radius of the $1^{1 / 1} 4^{-i n}$. round passing through the center of the specimen (fig. 4, D).

Tests were carried out in duplicate at room or low temperature in a Charpy machine of 224.1 $\mathrm{ft} / \mathrm{lb}$ capacity, with a striking velocity of the hammer of $16.85 \mathrm{ft} / \mathrm{sec}$. The procedure for making the tests at low temperature consisted of cooling the specimens in an insulated bath containing equal parts of carbon tetrachloride and chloroform for a minimum of 30 minutes at the desired temperature, and then quickly transferring to the impact machine and breaking. The desired temperatures were obtained by regulated additions of solid carbon dioxide, and as this material passes directly from the solid to a gas, no dilution occurred in the liquid bath. The temperature of the cooling bath was measured by means of a copperconstantan thermocouple and an indicating potentiometer. Rockwell "C" hardness measurements were made on the fractured specimens at room temperature. The hardness values given in figures 54 and 55 are the average of all the specimens used for each condition; a minimum of four determinations were made on each specimen. The values for notch toughness, summarized in the figures, are the averages obtained on duplicate specimens, except in a very few cases where the testing procedure was faulty, the value was not included; in several cases abnormally high values for energy were required to fracture or bend the specimens because of a wedging action between hammer, specimen, and frame of the machine.

\section{Tensile}

The tensile tests were made in duplicate with specimens prepared longitudinally to the direction of rolling from initially normalized $1 / 2$-in.-thick plates (fig. 1, B, section C) or 1/1/4-in. rounds (commercial steels). Prior to the quenching and tempering treatments, the experimental steels were rough machined to $1 / 2-i n$. rounds and the commercial steels to $3 / 8-, 0.52$ - to $0.55-$, or 1 -in. diameter in the reduced sections. The $3 / 8$-in. rounds of the commercial steels were prepared with their centers at half-radius, whereas the oversize $1 / 2$ - or 1 -in. rounds, and those tested in the annealed or normalized condition, were prepared from the center of the $1 \frac{1}{1} 4$-in. rounds. The reduced section of all the specimens was finished by wet grinding to size.

\section{Results}

\section{Transformations}

Tests were carried out to determine the effect of boron additions made with Ferroboron on the temperatures of the $A_{1}\left(A c_{1}\right.$ and $\left.A r_{1}\right)$ and $A_{3}$ $\left(A c_{3}\right.$ and $\left.A r_{3}\right)$ transformations of the following experimental steels containing 0.30 percent of carbon and (1) 0.8 and 1.6 percent of manganese (steels with 1.6 percent of manganese with boron additions made with Grainal No. 79 and Silcaz No. 3 also were included), (2) 1.6 percent of manganese and variable nitrogen, (3) 0.8 percent of manganese and variable nickel or chromium, (4) 0.8 percent of manganese, 0.5 percent of chromium and variable nickel. The results (illustrated for some of the steels in fig. 6) show that boron had no significant influence on the temperatures of $A_{1}$ and $A_{3}$ transformations of the steels investigated. Variations in nitrogen from about 0.005 


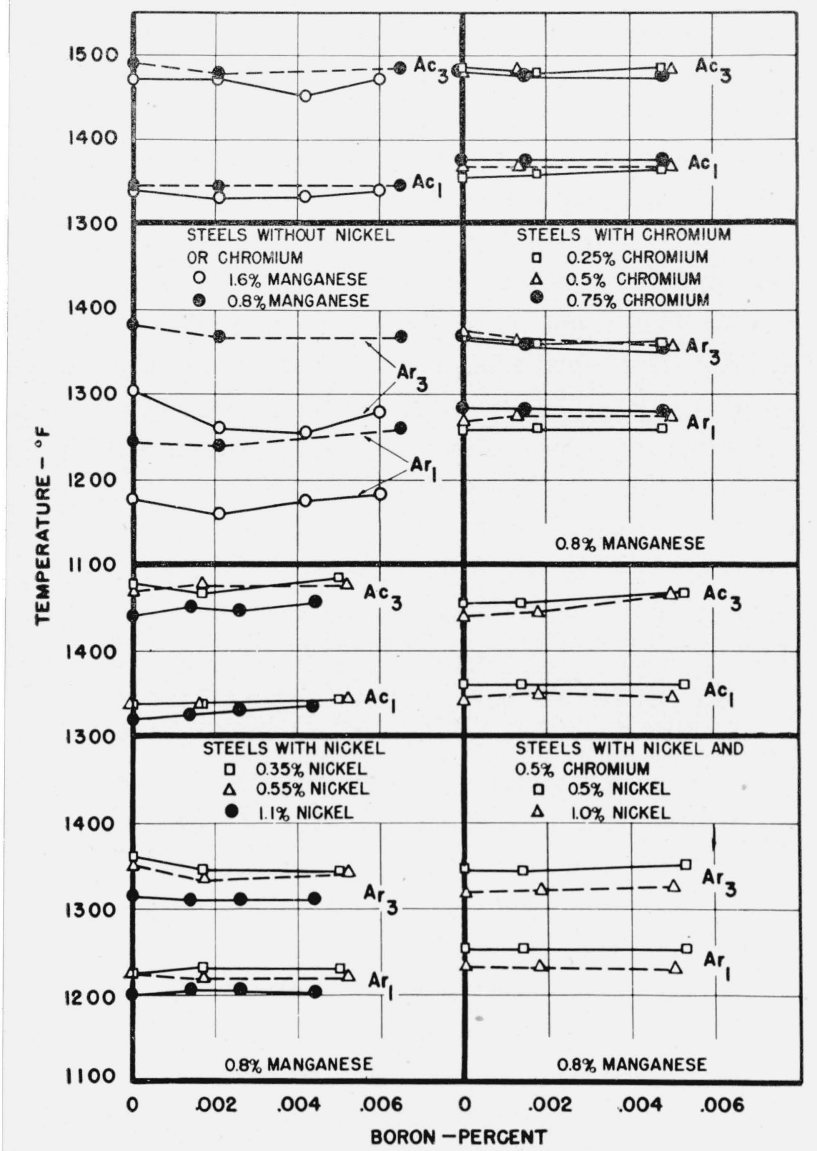

Figure 6.-Influence of boron on the transformation temperatures of experimental steels containing 0.3 percent of carbon, 0.8 or 1.6 percent of manganese and varying amounts of nickel and chromium.

to 0.025 percent in steels with and without boron also had no appreciable effect on the temperatures of the transformations on slow heating $\left(A c_{1}\right.$ and $A c_{3}$ ), but there was a slight trend for the temperatures of the transformations on slow cooling ( $A r_{1}$ and $\left.A r_{3}\right)$ to increase with the nitrogen content. There was also a trend for the temperature of $A c_{3}$ to be raised by the addition of titanium or by aluminum. However, the differences observed were usually within the limits of experimental error of the procedures. The temperature of $A c_{3}$ was not affected by a change in chromium from nil to 0.75 percent, whereas the temperature of this transformation decreased with increase in nickel content.

A change in rate of heating from about 10 to 125 deg $\mathrm{F}$ per minute had no noticeable effect on the temperature of the transformations $\left(A c_{1}\right.$ and $\left.A c_{3}\right)$ in 0.75 percent chromium steels containing 0 and 0.0048 percent of boron (steels 94 and 97 , table 5). The temperature of the $A r_{3}$ transformation decreased in both of these steels with increase in the rate of cooling and this trend was obtained with the $A r_{1}$ transformation.

The temperature of the start of the decomposition of austenite to martensite $\left(A r^{\prime \prime}\right.$ or $\left.M_{s}\right)$ was not affected by boron (addition made with Ferroboron) in steels containing 0.30 percent of carbon and (1) 1.6 percent of manganese and variable nitrogen; (2) 1.6 percent of manganese and 0.5 percent of chromium; (3) 0.8 percent of manganese, 0.5 percent of chromium and variable nickel. The start of this transformation was not affected by variation in nitrogen or by the addition of titanium to the steels tested.

\section{Austenite and McQuaid-Ehn Grain Sizes}

\section{(a) Experimental Steels}

The grain-coarsening temperature of the experimental steels varied with the base composition of the heat, deoxidation practice, boron content, and chemical composition of the ferroalloy used for making the boron additions.

The grain sizes established at the temperature used in hardening are included with the data given in the hardenability charts. The base steels (without boron) that were deoxidized with aluminum were fine-grained at the temperatures used in hardening (fig. 7, A); their coarsening temperature was between $1,650^{\circ}$ and $1,750^{\circ} \mathrm{F}$. The grain coarsening temperature was usually lowered by the addition of about 0.0015 percent of boron with Ferroboron (Fig. 7, A and B); the trend was for the average size of the grains at the hardening temperature to increase with further increase in boron content (fig. 7, B and C). It was possible, however, to prepare steels treated with Ferroboron for relatively high boron content that were finegrained in the temperature range used for hardening and normalizing. In general, the treatment of the steels with a complex ferroalloy containing boron was more effective than with Ferroboron in preventing grain coarsening at heat-treating temperatures. This is to be expected as Grainal No. 79 and Silcaz No. 3 contain appreciable amounts of grain growth inhibitors (aluminum and titanium) and the maximum amount of boron retained was usually lower than that of the heats prepared with Ferroboron. However, the trend was for the 
coarsening temperature of austenite to be lowered by boron irrespective of the composition of the ferroalloy used.

The effect of titanium on the austenite grain size of aluminum killed steels containing boron varied with the titanium, boron, and nitrogen content. The results obtained indicated that the role of each of the elements, titanium and nitrogen, is to raise the coarsening temperature of austenite in these steels, but the presence of both of these elements tend to neutralize their effectiveness as grain growth inhibitors. At steel-making temperatures, titanium reacts with nitrogen to form titanium nitride, a compound insoluble in austenite at heat-treating temperatures. Unlike alumina and some other insoluble oxides or undissolved carbides in austenite of plain carbon steels, titanium nitride inclusions of microscopic dimensions did not raise the grain coarsening temperature of these steels containing 0.0015 to 0.003 percent of boron to that of the high-nitrogen steel without boron. Many of the high-nitrogen steels, with and without boron, and several with boron and titanium or zirconium were fine-grained at $1,900^{\circ} \mathrm{F}$.

The grain size established in the hypereutectoid zone by carburizing at $1,700^{\circ} \mathrm{F}$ for $8 \mathrm{hr}$ varied to some extent with the base composition of the steels. In general, the steels without chromium, nickel, or molybdenum were somewhat coarser grained than the steels containing one or more of these elements, and there was some indication of coarsening due to boron in the former steels, especially when the amounts were relatively high.

(b) Commercial Steels

The grain size at the temperature used in hardening $\left(1,550^{\circ} \mathrm{F}\right)$ the commercial steels is given in figure 30 and the influence of boron on the grain size at this temperature is illustrated in the typical photomicrographs of figure 7, D, E, and F. At $1,550^{\circ} \mathrm{F}$, all the steels were fine-grained (fig. 7, D and F) except those containing relatively high additions with Ferroboron or Borosil; a few intermediate size grains were observed in specimens of the steels treated with low additions of Ferroboron, Borosil, Silcaz No. 3 (fig. 7, E) and Bortam. The trend was for the size of the grain at this temperature to decrease slightly with increase in boron when the additions were made in the mold with Silcaz No. 3 (fig. 7, E and F),
Grainal No. 79, Bortam, Grainal No. 1 and Silcaz No. 3, and to increase with boron in the steels treated with Ferroboron or Borosil (fig. 30). This latter trend for the grain size at the hardening temperature to increase with boron was similar to that of the experimental steels treated with Ferroboron, as illustrated in figure $7 \mathrm{~A}, \mathrm{~B}$, and $\mathrm{C}$.

The base steel (C15) was fine-grained at $1,650^{\circ}$ $\mathrm{F}$, the temperature used for normalizing, but some coarsening occurred at $1,750^{\circ} \mathrm{F}$. Some coarse grains were observed in a specimen heated at $1,650^{\circ} \mathrm{F}$ of steel $\mathrm{C} 6$ treated with a relatively small addition of Silcaz No. 3, whereas the coarsening temperature was above $1,750^{\circ} \mathrm{F}$ in steel C8 similarly treated except for higher additions of this complex ferroalloy. Thus the trend was for the austenite grains to increase in size by the addition of boron, but the grain growth tendency was somewhat counteracted by including sufficient amounts of certain grain refining elements with the additions.

The size of the grains established in both the carburized case and in the core (McQuaid-Ehn test) also varied with the different steels. Intermediate to fine grains (American Society for Testing Materials Grain No. 5 to 8) were obtained in the case of all steels except those treated with relatively high addition of boron with Ferroboron or Borosil; the average size of the grains of the latter steels (C13, C14, and $\mathrm{C} 26$ ) ranged from American Society for Testing Materials number 4 to 6 . Intermediate to coarse grains were observed in the core of all the steels.

\section{Hardenability}

Grossmann [19] has presented data showing the relation of carbon content to hardness (Rockwell C) for a structure containing 50 percent martensite in plain carbon and low-alloy steels. This structure is obtained in the zone where the formation of pearlite is most rapid during the quenching of a bar that hardens at the surface but remains unhardened in a part of the interior. The location of this zone is usually readily revealed by a change in appearance from the hardened case to the unhardened core of a fractured or polished and etched cross section. As the point of inflection in hardenability curves showing the relation of the depth of hardening to structure (or hardness) corresponds to a structure of about 50 percent martensite, a determination of this 

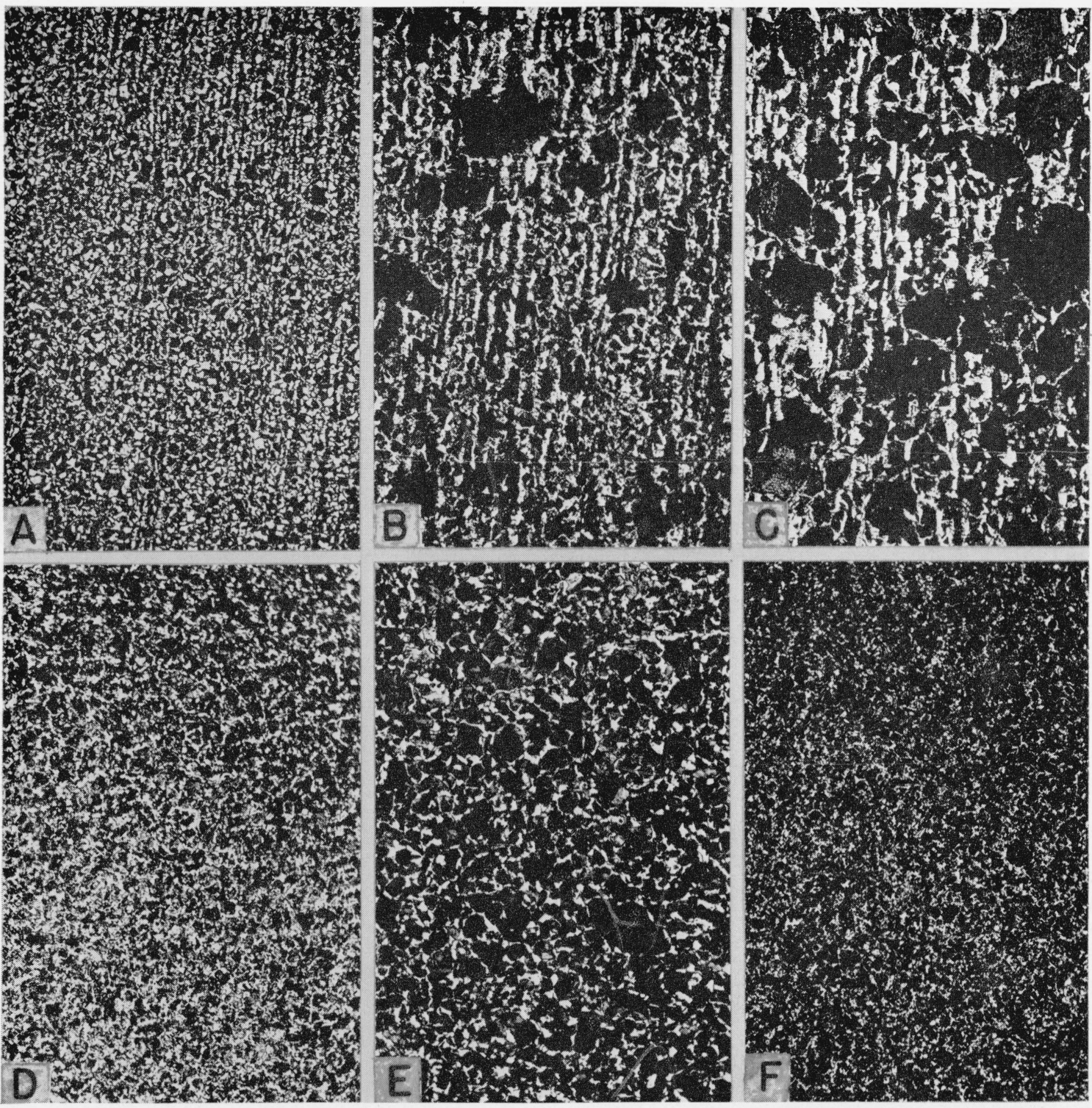

FIGURE 7.- Influence of boron on the grain size at temperatures used in hardening experimental and commercial steels.

Etched with $1 \%$ nital, $\times 100 ; \mathrm{A}, \mathrm{B}$, and $\mathrm{C}$, experimental steels; D, E, and F, commercial steels.

\begin{tabular}{|c|c|c|c|c|c|}
\hline \multirow{2}{*}{ Figure } & \multirow{2}{*}{ Steel No. } & \multicolumn{2}{|c|}{ Boron } & \multirow{2}{*}{$\begin{array}{l}\text { Temp- } \\
\text { erature }\end{array}$} & \multirow{2}{*}{$\begin{array}{c}\text { ASTM } \\
\text { Grain No. }\end{array}$} \\
\hline & & Agent & Amount & & \\
\hline A. & $1 \ldots$ & None. & $\begin{array}{c}\text { Percent } \\
\text { None }\end{array}$ & $\begin{array}{l}{ }^{\circ} F \\
1,575\end{array}$ & \\
\hline $\mathrm{B}_{-}$ & $2 \ldots$ & Ferroboron & 0.0015 & 1,575 & 7 , few 4 to 6 \\
\hline $\mathrm{C}_{-}$. & 4 & .... do & .0060 & 1,575 & 3 to 7. \\
\hline D . & $\mathrm{C} 15 \ldots$ & None & $<.0001$ & 1,550 & \\
\hline $\mathrm{E}_{\text {. }}$ & C6 ... & Silcaz No. 3 & .0009 & 1,550 & 7 , few 5 \\
\hline$F_{\ldots} \ldots$ & C8 $\ldots$ & _..... do _.... & .0031 & 1,550 & 8. \\
\hline
\end{tabular}

point, either by microscopic examination or by hardness testing, in suitable specimens quenched under controlled conditions is a method commonly used as an index to hardenability. According to Jominy [20], however, a decrease in hardness of about 5 points Rockwell $\mathrm{C}$ from the water cooled end of the Jominy bar corresponds roughly to the formation of about 5 percent pearlite $(95 \%$ of martensite), and such a point on the Jominy bar is a value that is used for a practical determination of hardenability. 
The relation of carbon content of the present steels to Rockwell C hardness for structures containing 50 and 95 percent martensite is given in table 10. The hardness values used for 50 percent martensite were obtained from the data reported by Grossmann [19], whereas the hardness values for 95 percent martensite were established from the results of some of the end-quench tests. The latter values were 5 to 10 points Rockwell C lower than those obtained $1 / 16$ inch from the water-cooled end of the bar. Some of these hardness values are appreciably lower than those that were recently reported by Hodge and Orehoski [21] for steels of similar carbon content and structures.

TABLE 10.-Relation of carbon content to hardness for structures containing 50, or 95 percent martensite

\begin{tabular}{|c|c|c|}
\hline \multirow{2}{*}{ Carbon, $\%$} & \multicolumn{2}{|c|}{ Hardness, Rockwell C } \\
\hline & $\begin{array}{l}50 \% \text { mar- } \\
\text { tensite }{ }^{1}\end{array}$ & $\begin{array}{l}95 \% \text { mar- } \\
\text { tensite }\end{array}$ \\
\hline 0.20 & 32 & 37 \\
\hline $\begin{array}{l}0.30 \\
0.45\end{array}$ & $\begin{array}{l}35 \\
42\end{array}$ & $\begin{array}{l}45 \\
50\end{array}$ \\
\hline
\end{tabular}

${ }^{1}$ Data obtained from Grossmann [19] (Metal Technology, June 1942 TP1437).

${ }^{2}$ Data obtained from the end-quench tests.

End-quench tests were made on initially normalized specimens quenched from the usually recommended temperature range of all the experimental and commercial steels listed in tables 1 to 8 , and the results are presented in hardenability charts of figures $8,11,13,14,19,21,24,26$, and 30 . The curves of all the steels comprising an experimental heat are assembled in the same group, and the curves for the commercial steels are grouped according to the trade name of the intensifier used. The curve for the steel without boron $(\mathrm{C} 15)$ is also included in each group in the latter figure. Data on the chemical composition of the steels, trade name or type of intensifier, quenching temperature and grain size at the quenching temperature are given with each of these charts.

Although the relative hardenability of the various steels is obtained by a comparison of these curves, it is considerably more convenient to show the magnitude of the hardenability effect due to boron (or other variable) from heat to heat by comparing the distances from the quenched end of the Jominy bars corresponding to the same selected hardness values or structures. Comparisons, therefore, are made of the hardenability of the various steels on the basis of the distances from the quenched end of the bar for hardness values corresponding to both 50 and 95 percent of martensite. Obviously, the greater the distance from the quenched end at which either of these two structures is produced, the greater is the hardenability of the steel. It should be pointed out that the order of arrangement of the steels as given in terms of hardenability possibly would change with a change in basis for comparison or method for determining hardenability. Furthermore, the standard endquench test is not suitable for determining the hardenability of steels that harden throughout in $3 / 4^{-}$to 1 -in. or larger rounds by cooling in still air. Some of the experimental steels used in the present investigation, notably those containing both nickel and chromium (fig. 24), or chromium and molybdenum (fig. 26) were of the deepor air-hardening type. However, the end-quench test was also carried out on specimens of the latter steels with the thought that some indication, perhaps not especially precise, would be obtained of the difference in hardenability arising from heat to heat and from the additions of varying amounts of boron.

\section{(a) Experimental Steels}

1. Carbon-manganese.-The curves obtained from the results of the end-quench tests of the carbon-manganese steels listed in table 1 are given in figure 8 .

The effect of boron on the hardenability (on the basis of the distance from the quenched end of the Jominy bar for 50 and 95 percent of martensite) of these steels with 0.3 percent of carbon and variable manganese, and with 1.6 percent of manganese and variable carbon is shown in figure 9. Boron had a marked influence on the hardenability of these steels. However, the improvement in hardenability due to boron varied not only with the boron content but also with the base composition (carbon and manganese) of the steels. With steels containing 0.3 percent of carbon and 0.8 or 1.25 percent of manganese or 0.2 percent of carbon and 1.6 percent of manganese, the hardenability increased continuously with increase in boron, but the improvement in hardenability with 0.006 percent 


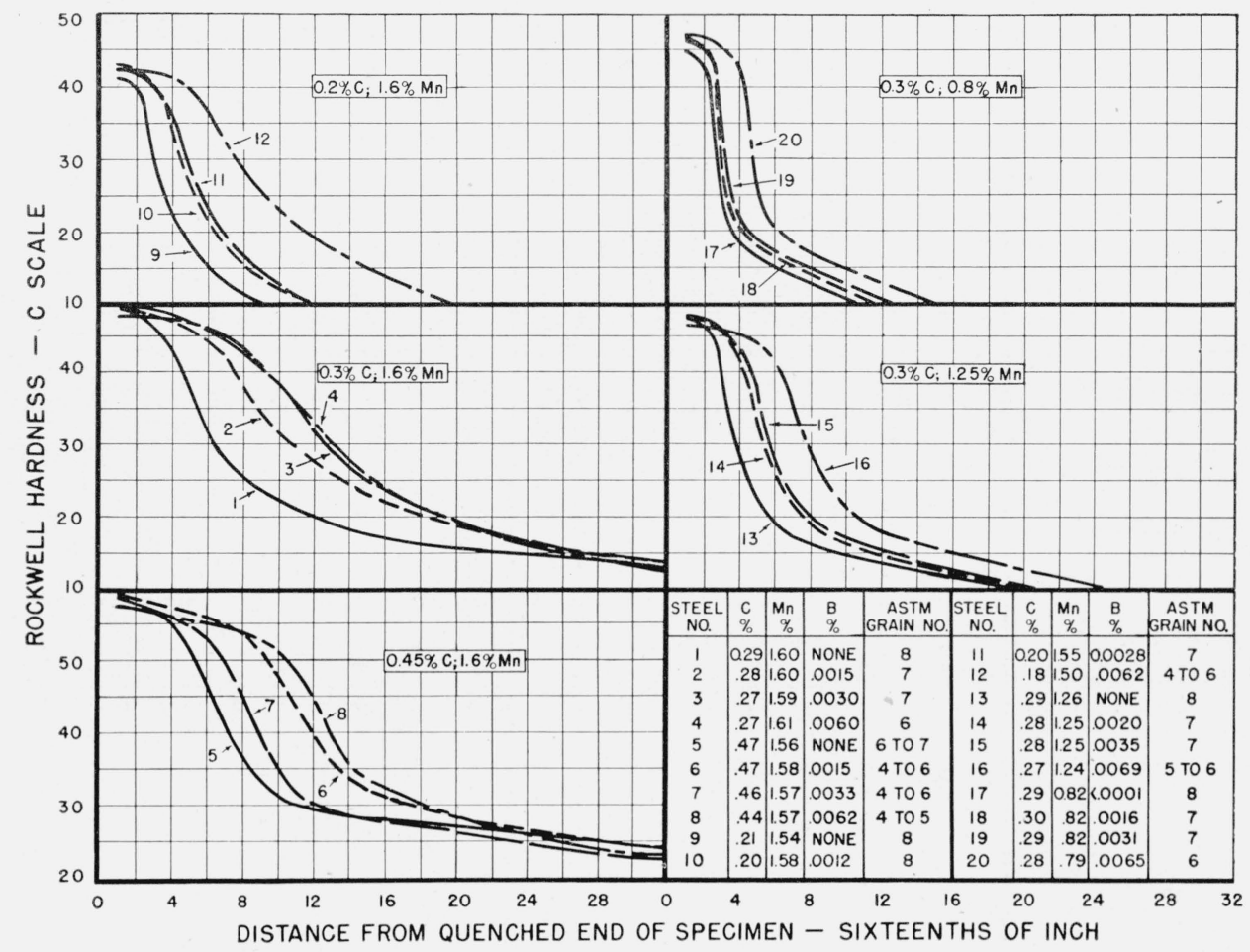

FIGURE 8.-Hardenability curves of experimental carbon-manganese steels.

The chemical composition of the steels is given in table 1. Each heat was deoxidized with 0.10 percent of aluminum before adding the boron in the furnace with Ferroboron. Specimens were normalized at $1,575^{\circ} \mathrm{F}$ (steels 5 to 8 ) or $1,650^{\circ} \mathrm{F}$ (steels 1 to 4,9 to 20 ) and end-quenched from $1,475^{\circ} \mathrm{F}$ (steels 5 to 8 ) or $1,575^{\circ} \mathrm{F}$ (steels 1 to 4 and 9 to 20 ); ASTM grain number at the quenching temperature.

of boron was no greater than with 0.003 percent in the 0.3 percent carbon, 1.6 percent manganese steel. The latter two steels $(0.003$ and $0.006 \%$ of boron) were deeper hardening than the 0.0015 percent boron steel with similar carbon and manganese content. With the 0.45 percent carbon steels, the maximum increase in hardenability was obtained with the retention of 0.0062 percent of boron, although 0.0033 percent was not as effective as 0.0015 percent.

The influence of carbon on the hardenability of the 1.6 percent manganese steels and the effect of manganese on the hardenability of steels with 0.3 percent of carbon is shown in figure 10. Obviously, the hardenability of the steels, with and without boron, increased with increase in manganese. An interesting feature is that the manganese was more effective in increasing the hardenability of steels with boron than in the steels without this element. Comparison of the curves also show that the depth of hardening of 0.8 percent manganese steel with about 0.006 percent of boron was equivalent to that of 1.6 percent manganese steel without boron. That is, the increase in hardenability due to 0.006 percent of boron was equivalent to that produced by an increase in about 80 points of manganese. Except for the steels with 0.003 percent of boron, the hardenability of the 1.6 percent manganese steels also increased with increase in carbon content. An indication of the effectiveness of boron as a substitute for carbon in order to produce equivalent hardenability may be obtained by a comparison of these curves. The steels with 0.18 percent of carbon and 0.006 percent of boron hardened to a somewhat greater depth than did the plain steel with 0.47 percent of carbon. That is, the increase in hardenability due to about 0.006 percent of boron was equivalent to that produced by about 30 points of carbon.

The results summarized in figures 9 and 10 also show that the effectiveness of boron in improving hardenability tended to increase with manganese content up to 1.6 percent and with carbon content up to about 0.3 percent, provided comparisons are made of the steels (without boron, with those containing boron that developed 


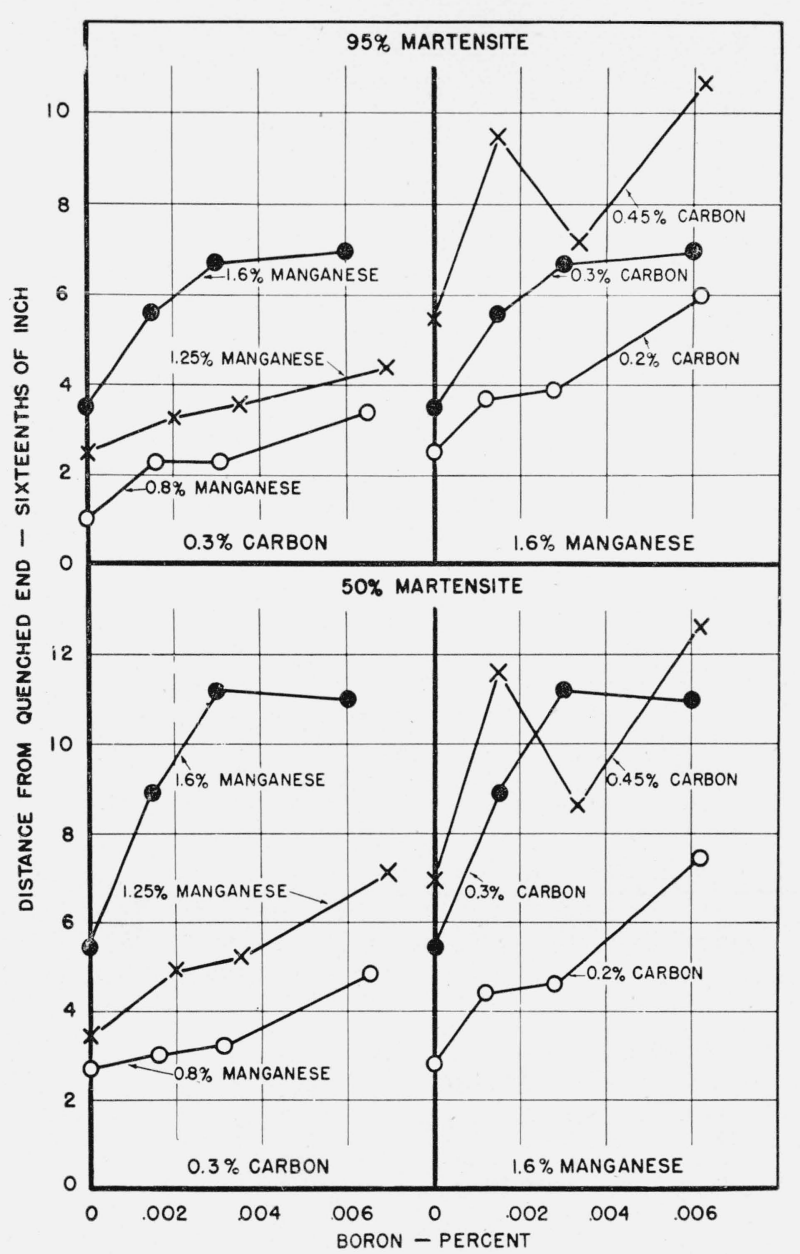

FIGURE 9.-Influence of boron on the hardenability of experimental carbon-manganese steels.

The chemical composition of the steels ( 1 to 20 ) is given in table 1.

the maximum hardenability) on the basis of change in distances from the quenched end of the Jominy bar for structures of either 50 or 95 percent of martensite. The percentage change, however, decreased slightly with increase in carbon in the steels with 1.6 percent of manganese.

2. Deoxidation practice.-The hardenability curves obtained from the results of the endquench tests of the carbon-manganese steels deoxidized in different ways and listed in table 2 are given in figure 11 and data from these curves are assembled in figure 12 . The hardenability of these steels varied with the boron content, deoxidation practice and composition of the ferroalloys used as intensifiers.

For steels deoxidized with aluminum before making the ${ }^{\prime}$ boron additions (fig. 12), the harden-

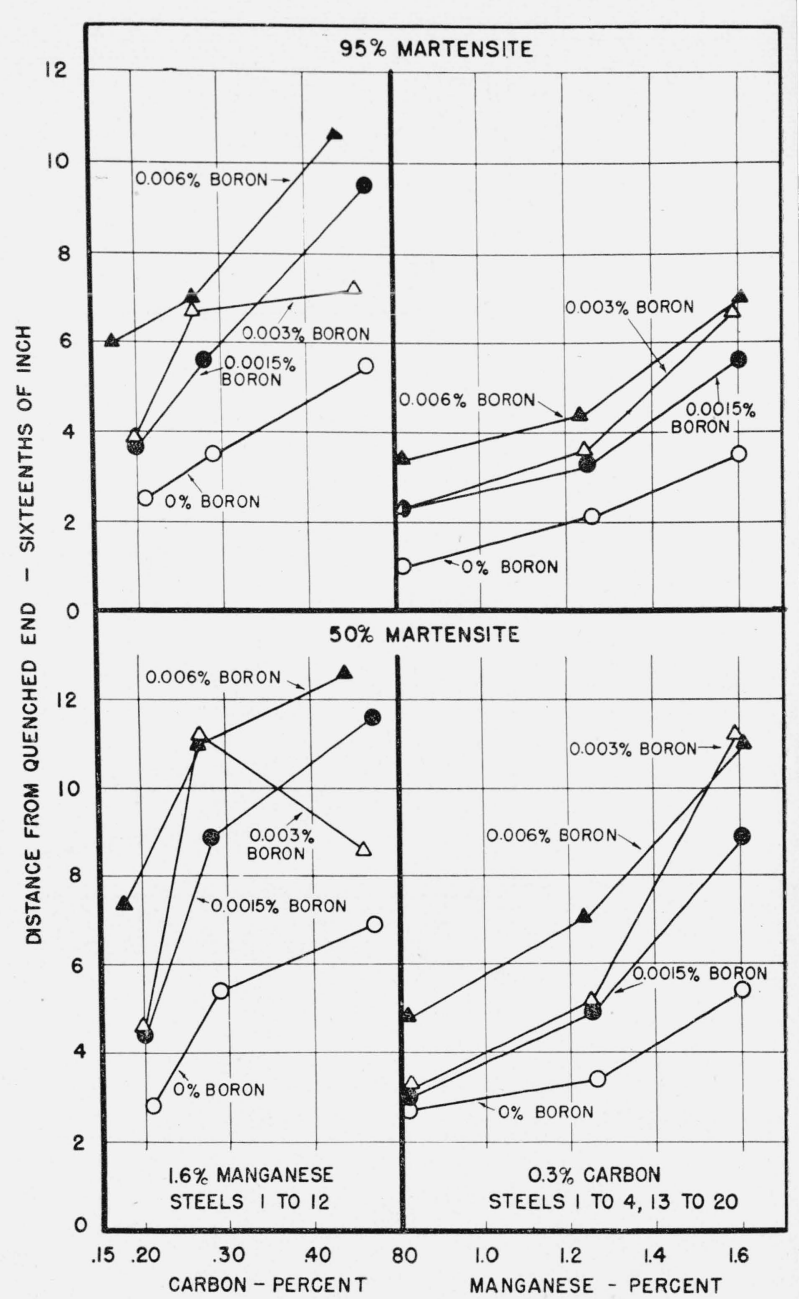

Figure 10.-Relation of carbon and manganese content to the hardenability of experimental steels.

The chemical composition of the steels is given in table 1.

ability was enhanced by all additions of boron with Ferroboron, by 0.0008 percent or more of boron with Grainal No. 79, and by 0.0025 percent or more of boron with Silcaz No. 3. The hardenability was increased only slightly by 0.0001 , 0.0004 or 0.0006 percent of boron in the steels treated with Grainal No. 79 and by $0.0003,0.0006$, or 0.0008 percent of boron in the steels treated with Silcaz No. 3. Unfortunately, steels with similar low amounts of boron were not prepared with Ferroboron. The maximum hardenability that was attained in the steels treated with Silcaz was somewhat greater than that of the steels treated with Ferroboron or Grainal. (The lower hardenability of the Grainal treated steel may be due to its much lower boron content; its silicon 


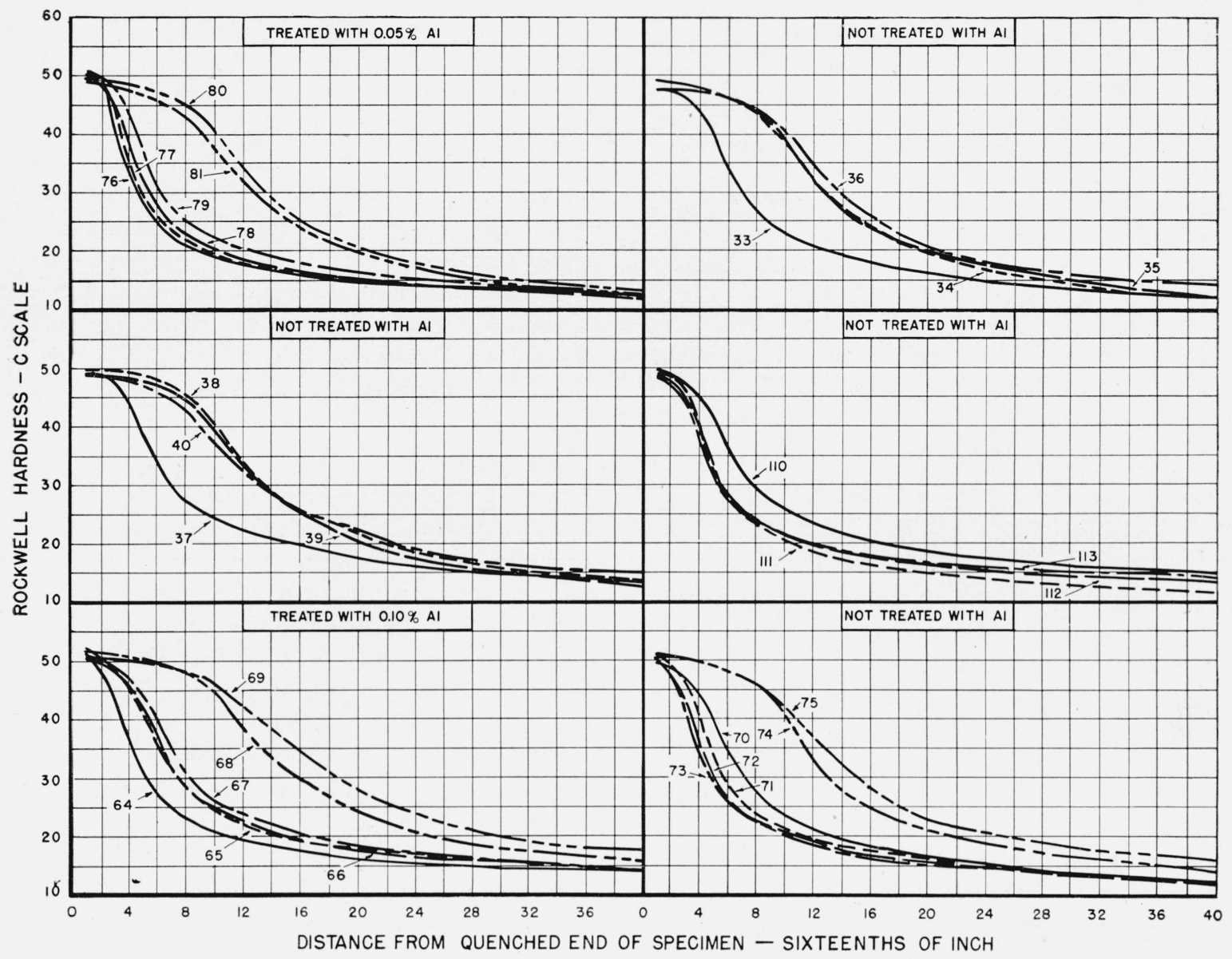

FIGURE 11.-Hardenability curves of experimental carbon-manganese steels prepared with different deoxidation practices.

The chemical composition of the steels $(0.3 \% \mathrm{C}, 1.6 \% \mathrm{Mn})$ is given in table 2. Specimens were normalized at $1,650^{\circ} \mathrm{F}$ and end-quenched from $1,575^{\circ} \mathrm{F}$.

\begin{tabular}{|c|c|c|c|c|c|c|c|}
\hline \multirow{2}{*}{$\begin{array}{l}\text { Steel } \\
\text { No. }\end{array}$} & \multicolumn{2}{|c|}{ Boron } & \multirow{2}{*}{$\begin{array}{c}\text { ASTM } \\
\text { Grain No. } \\
\text { at } 1,575^{\circ} \mathrm{F}\end{array}$} & \multirow{2}{*}{$\begin{array}{l}\text { Steel } \\
\text { No. }\end{array}$} & \multicolumn{2}{|c|}{ Boron } & \multirow{2}{*}{$\begin{array}{c}\text { ASTM } \\
\text { Grain No. } \\
\text { at } 1,575^{\circ} \mathrm{F} \text {. }\end{array}$} \\
\hline & Agent & Amount & & & Agent & Amount & \\
\hline 76 & None. & $\begin{array}{l}\text { Percent } \\
\text { None }\end{array}$ & 8 & 111 & None... & $\begin{array}{l}\text { Percent } \\
\text { None }\end{array}$ & \\
\hline 77 & Grainal No. 79 & 0.0001 & 8 & 112 & ... do & None & \\
\hline 78 & do do & .0004 & 8 & 113 & _.... do _. & None & 8 \\
\hline 79 & do & .0006 & 8 & 64 & ... do . . . & None & 8 \\
\hline 80 & do & .0008 & 8 & 65 & Silcaz No. 3 & 0.0003 & \\
\hline 81 & _..._do do & .0017 & 8 & 66 & _... do _ _... & .0006 & 8 \\
\hline 33 & None & None & 4 to 7 & 67 & ........... & .0008 & 8 \\
\hline 34 & Grainal No. 79 & 0.0010 & 4 to 8 & 68 & do $\ldots$.... & .0025 & 8 \\
\hline 35 & do & .0018 & 8 & 69 & _. do _... & .0041 & 8 \\
\hline 36 & do do & .0033 & 7 to 8 & 70 & None .......... & None & 3 to 7 \\
\hline 37 & None & None & 4 to 7 & 71 & Silcaz No. $3 \ldots$ & 0.0004 & 4 to 8 \\
\hline 38 & Synthetic mixture ... & 0.0014 & 3 to 8 & 72 & _.... do _... & .0006 & 8 \\
\hline 39 & do & .0024 & 8 & 73 & ..... do ... & .0015 & 8 \\
\hline 40 & _. do & .0051 & 7 to 8 & 74 & $\ldots$ do $\ldots . .$. & .0027 & 8 \\
\hline 110 & None & None & 4 to 7 & 75 & ..... do .. & .0086 & 8 \\
\hline
\end{tabular}




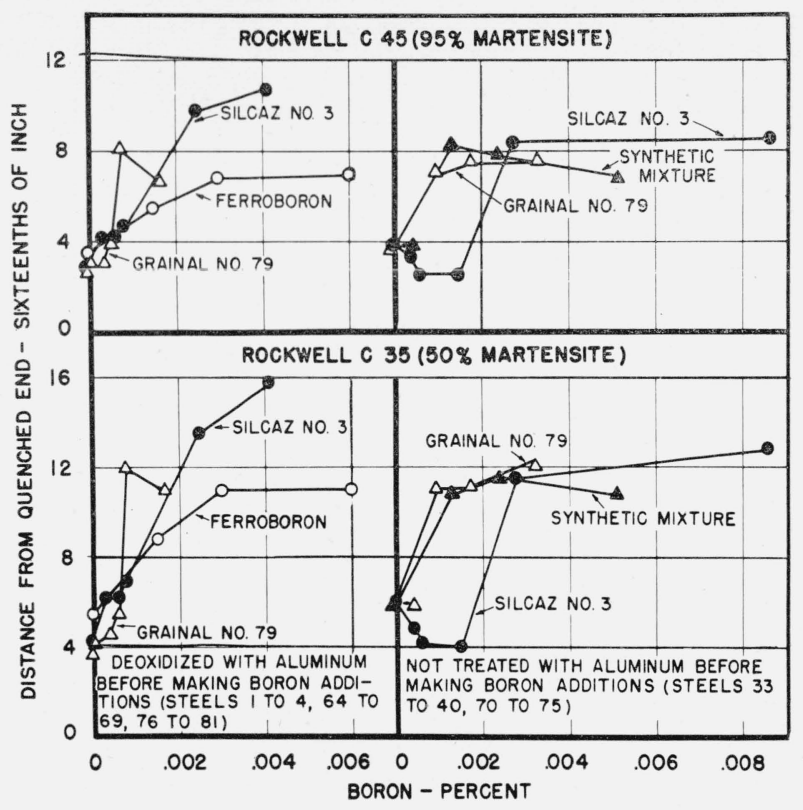

Figure 12.-Influence of boron on the hardenability of experimental carbon-manganese steels treated with different intensifiers.

The chemical composition of the steels $(0.3 \% \mathrm{C}, 1.6 \% \mathrm{Mn})$ is given in tables 1 and 2 .

content was also appreciably lower than that of the steel treated with Silcaz).

For the steels not initially deoxidized with aluminum, the treatment with Silcaz No. 3 for boron content of $0.0004,0.0006$, and 0.0015 percent resulted in a decrease in hardenability but with higher amounts (0.0027 and $0.0086 \%$ of boron) the hardenability was improved markedly. The decrease in hardenability of the steels with low boron $(0.0004$ and $0.0006 \%)$ is believed to be due principally to a difference in grain size at the hardening temperature of $1,575^{\circ} \mathrm{F}$; the hardenability of a steel usually increases with the size of the austenite grains. As the heat was not killed with aluminum before adding the intensifier, the base steel was relatively coarse-grained at the hardening temperature. Some grain refinement (at $1,575^{\circ} \mathrm{F}$ ) resulted from the treatment with sufficient Silcaz to produce a boron content of 0.0004 percent. These steels were fine-grained when treated with this intensifier for a boron content of 0.0006 and 0.0015 percent. The hardenability of the steels comprising the heats treated with Grainal No. 79 or with a synthetic mixture similar in chemical composition to the Grainal was improved considerably by all addi- tions of boron. However, the retention of about 0.001 percent of boron was just as effective as amounts ranging up to about 0.005 percent. The increase in hardenability of the steels treated alike with the synthetic mixture or Grainal No. 79 was of the same order of magnitude and was about the same as the maximum attained in the steels treated with Silcaz No. 3. It is noteworthy that the steel treated with Silcaz No. 3 for 0.0015 percent of boron (Steel 73) was not as deep hardening as the base steel or other steels with greater or less amounts of boron. These results were checked with another end-quenched specimen of the same steel $(0.0017 \%$ of boron $)$.

For the steels treated with a synthetic mixture without boron (fig. 11, steel 110 to 113) the hardenability of the base steel (without titanium, zirconium, or aluminum, steel 110) was greater than that of the other steels from the same heat that contained 0.03 to 0.09 percent of titanium, 0.006 to 0.007 percent of zirconium and 0.005 to 0.09 percent of aluminum. This heat was not deoxidized with aluminum previously to making the additions of the synthetic mixture containing titanium, zirconium, and aluminum (the chemical composition of the mixture was similar to Grainal No. 79, except that boron was omitted.) The base steel was relatively coarse-grained at the hardening temperature of $1,575^{\circ} \mathrm{F}$, whereas the steels with titanium and zirconium were finegrained. The observed difference in hardenability of the steels comprising this heat, therefore, is believed to be due primarily to a difference in grain size at the hardening temperature, or to the absence or presence of titanium of zirconium inclusions in the austenite.

The steels treated with Silcaz No. 3, Grainal No. 79, or a synthetic mixture contained varying amounts of titanium and zirconium in addition to boron. That the improvement in hardenability was due primarily to the boron content and not to titanium or zirconium is shown by a comparison of the hardenability curves of these borontreated steels with those for the steels similar in composition except for the omission of boron. The steels containing titanium, zirconium, and boron were deep-hardening (except as pointed out for 71,72 , and 73 ) relative to the steels with only titanium and zirconium.

An indication of the reproducibility of the hardenability of the experimental steels from heat to 
heat is obtained by a comparison of the values of the base steels given in figure 12. Except for the somewhat higher hardenability of one of the base steels (steel 1), the values for the steels prepared alike agree very closely. The steels killed with aluminum (except steel 1) were shallower hardenng than the nonkilled steels. This difference in hardenability may be explained on the basis of variations in grain size at the hardening temperature.

3. Nitrogen.-The curves obtained from the results of the end-quench tests of the nitrogen steels listed in table 3 are given in figures 13 and 14 .

Three preliminary heats, namely, 9079, 9080, and 9081 were made to determine whether the presence of about 0.015 percent of nitrogen affected the hardenability of steels with 0.0 and 0.2 percent of titanium, treated with Ferroboron for 0.006 percent of boron. Unfortunately, the carbon in two of the heats was below the desired amount. The preliminary results, however, indicated that the hardenability of steels with about 0.010 and 0.015 percent of nitrogen was not enhanced by the addition of 0.006 percent of boron (less than $0.006 \%$ of boron retained in some of the steels) without titanium whereas the hardenability was improved in the boron-treated steels containing a small amount of titanium. Additional heats, therefore, were prepared with variable nitrogen, 0.0 and 0.2 percent of titanium added as ferrotitanium, and 0.0015 and 0.003 percent of boron added as Ferroboron. One steel from each of these heats was also treated with Grainal No. 79 for a boron content of 0.0015 percent. Other heats were made with a high nitrogen content, and 0.0015 percent of boron added with Ferroboron with and without titanium, zirconium, chromium, or chromium and titanium. The hardenability of the base steels (without boron) was not materially affected by a change in nitrogen from 0.003 to 0.027 percent, as is shown in figure 15. However, variations in nitrogen of this magnitude had a pronounced effect on the hardenability of the steels that were treated with Ferroboron and did not contain titanium. In the lownitrogen $(0.003$ to $0.005 \%)$ steels, the addition of boron markedly improved the hardenability, whereas this property was not significantly affected by the additions in the steels containing about 0.010 percent or more of nitrogen. That is, the beneficial effect of boron on hardenability of the steels comprising these heats was obtained only in the low-nitrogen steels. The action of boron in increasing hardenability, however, was maintained to a considerable degree in the high-nitrogen steels by the addition of titanium either as a separate addition with ferrotitanium or as a complex intensifier (Grainel No. 79).

The effect of titanium on the hardenability of two additional heats of high-nitrogen-boron steels ( 0.020 percent of nitrogen, 0.0015 percent of boron, addition with Ferroboron) is also shown by the curves of figure 16. There was some difference in the hardenability of the two steels without titanium each with 0.0013 percent of boron, and the value for one steel containing titanium appears to be out of line with the remaining steels of this particular heat. The trend was for the hardenability of the steels of each heat to increase with titanium (retained) from 0 to about 0.08 percent and then to decrease with further increase in titanium (only one heat with retained titanium in excess of 0.1 percent).

The hardenability of the steels from two heats containing high nitrogen and varying amounts of chromium (fig. 17) was not materially increased by 0.0015 percent of boron (addition with Ferroboron), whereas the hardenability was improved by boron when the steels were also treated with titanium.

The hardenability data for the steels treated with zirconium are given in figure 18. Additions ranging from 0.0 to 0.20 percent of zirconium were made to one heat, but the maximum amount recovered was less than 0.01 percent. Considerably higher additions, therefore, were made to some of the steels of the other heat and a maximum concentration of about 0.6 percent of zirconium was attained. All these steels were treated for high nitrogen and for 0.0015 percent of boron (with Ferroboron). The hardenability of the steels comprising the heat with less than 0.01 percent retained zirconium (steels 162 to 16.7) decreased with increase in amount added. The hardenability of the steels of the other heat (steels 192 to 197) was not appreciably affected by the retention of zirconium up to about 0.07 percent, but the hardenability was improved when the amount of zirconium was in excess of 0.20 percent. The presence of zirconium nitride inclusions was observed only in the latter steels with the relatively high hardenability. The wide difference in hard- 


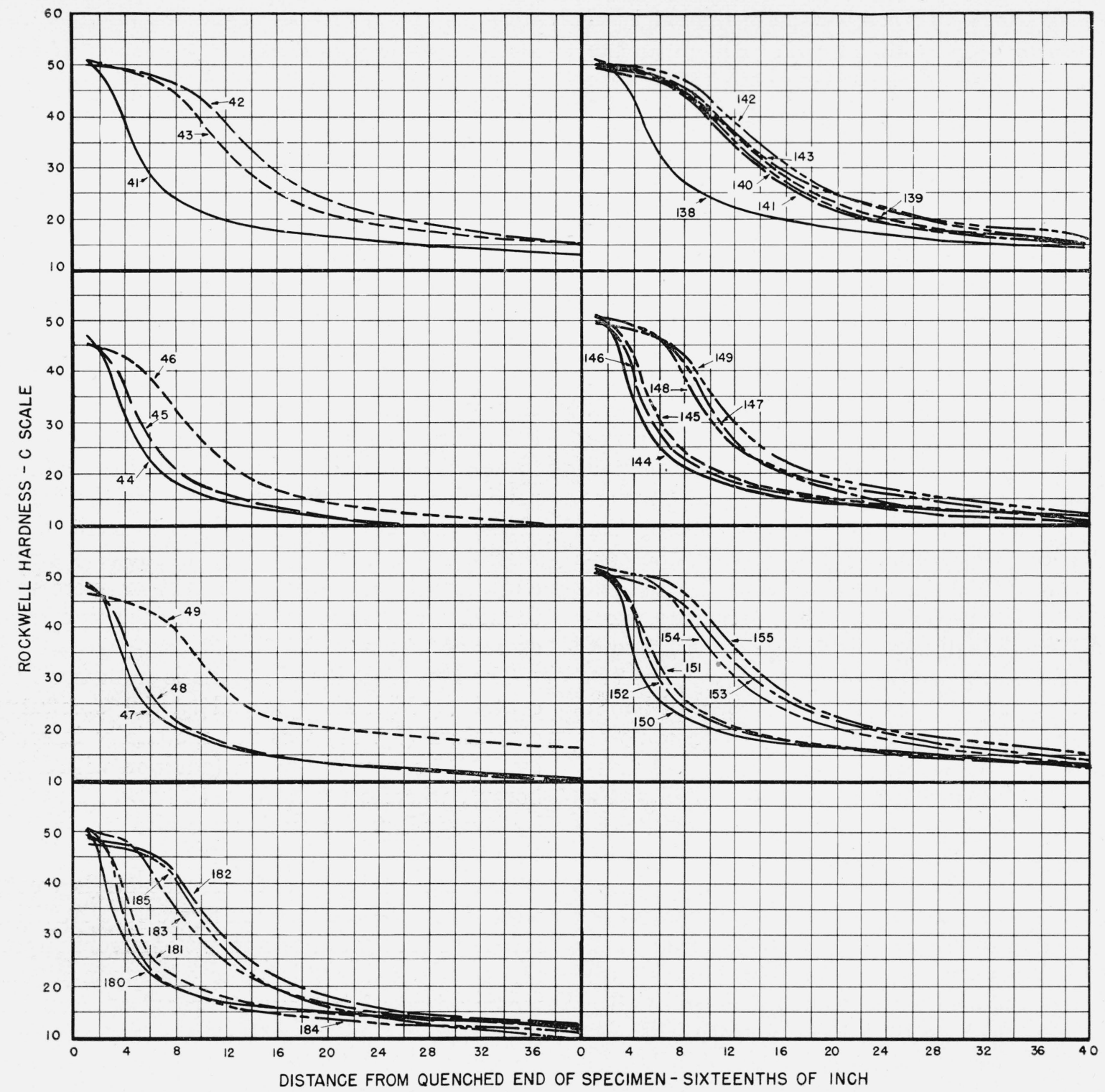

FiguRE 13.-Hardenability curves of experimental nitrogen steels containing 0.3 percent of carbon and 1.6 percent of manganese

The chemical composition of the steels is given in table 3 . Each heat was deoxidized with 0.10 percent of aluminum before adding the boron in the furnace with Ferroboron or in the ladle with Grainal No. 79. Specimens were normalized at $1,650^{\circ} \mathrm{F}$ and end-quenched from $1,575^{\circ} \mathrm{F}$.

\begin{tabular}{|c|c|c|c|c|c|c|c|c|c|c|c|}
\hline \multirow{2}{*}{$\begin{array}{l}\text { Steel } \\
\text { No. }\end{array}$} & \multicolumn{2}{|c|}{ Boron } & \multirow{2}{*}{$\mathrm{Ti}$} & \multirow{2}{*}{$\mathrm{N}$} & \multirow{2}{*}{$\begin{array}{c}\text { ASTM } \\
\text { Grain } \\
\text { No.at } \\
1575^{\circ} \mathrm{F}\end{array}$} & \multirow{2}{*}{$\begin{array}{l}\text { Steel } \\
\text { No. }\end{array}$} & \multicolumn{2}{|c|}{ Boron } & \multirow{2}{*}{$\mathrm{Ti}$} & \multirow{2}{*}{$\mathrm{N}$} & \multirow{2}{*}{$\begin{array}{c}\text { ASTM } \\
\text { Grain } \\
\text { No. at } \\
1575^{\circ} \mathrm{F}\end{array}$} \\
\hline & Agent & Amount & & & & & Agent & Amount & & & \\
\hline & None. & $\begin{array}{c}\text { Percent } \\
\text { None }\end{array}$ & $\begin{array}{l}\text { Percent } \\
\text { None }\end{array}$ & $\begin{array}{r}\text { Percent } \\
0.0035\end{array}$ & & & Ferroboron & $\begin{array}{c}\text { Percent } \\
0.0020\end{array}$ & $\begin{array}{r}\text { Percent } \\
0.11\end{array}$ & $\begin{array}{c}\text { Percent } \\
0.010\end{array}$ & 8 \\
\hline $\begin{array}{l}41 \\
42\end{array}$ & Ferroboron & 0.0042 & None & $\begin{array}{l}.0050 \\
.003\end{array}$ & 3 to 6 & $\begin{array}{r}149 \\
47\end{array}$ & $\begin{array}{l}\text { Ferrobo } \\
\text { None_.. }\end{array}$ & None & $\begin{array}{l}\text { None } \\
\text { None }\end{array}$ & $\begin{array}{l}0.014 \\
.014\end{array}$ & $\begin{array}{l}8 \\
8\end{array}$ \\
\hline 43 & do & .0044 & 0.13 & .0035 & 8 & 48 & Ferroboron & 0.0053 & None & .013 & 8 \\
\hline 138 & None & None & None & .005 & 8 & 49 & do & .0049 & 0.17 & .015 & 8 \\
\hline 139 & Ferroboron & 0.0016 & None & .005 & 7 to 8 & 150 & None. & None & None & .014 & 8 \\
\hline 140 & ..... do_... & .0030 & None & .006 & 7 to 8 & 151 & Ferroboron_. & 0.0017 & None & .013 & 8 \\
\hline 141 & & .0035 & 0.12 & .006 & 8 & 152 & ... do $\ldots$ & .0032 & None & .018 & 8 \\
\hline 142 & Grainal No. 79 & .0010 & .03 & .004 & 7 to 8 & 153 & 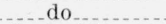 & .0025 & 0.10 & .017 & 7 to 8 \\
\hline 143 & Ferroboron & .0015 & .11 & .007 & 8 & 154 & Grainal No. 79 & .0009 & .02 & .014 & 8 \\
\hline 44 & None & None & None & .0085 & 8 & 155 & Ferroboron - & .0013 & .06 & .016 & 8 \\
\hline 45 & Ferroboron & 0.0059 & None & .0085 & 8 & 180 & None- & None & None & .027 & 8 \\
\hline 46 & & & 0.20 & .011 & 8 & 181 & Ferroboron & 0.0014 & None & .025 & 8 \\
\hline 144 & None & None & None & .007 & 8 & 182 & & .0019 & 0.17 & .017 & 8 \\
\hline 145 & Ferroboron. & 0.0018 & None & .009 & 8 & 183 & Grainal No. 79 & .0006 & .02 & .021 & 8 \\
\hline 146 & ..... do & .0026 & None & .009 & 8 & 184 & Ferroboron & .0026 & None & .023 & 8 \\
\hline 147 & ..... do .. & .0037 & 0.11 & .013 & 8 & 185 & .... do do..... & .0024 & 0.15 & .024 & 8 \\
\hline 148 & Grainal No. 79 & .0010 & .02 & .010 & 8 & & & & & & \\
\hline
\end{tabular}




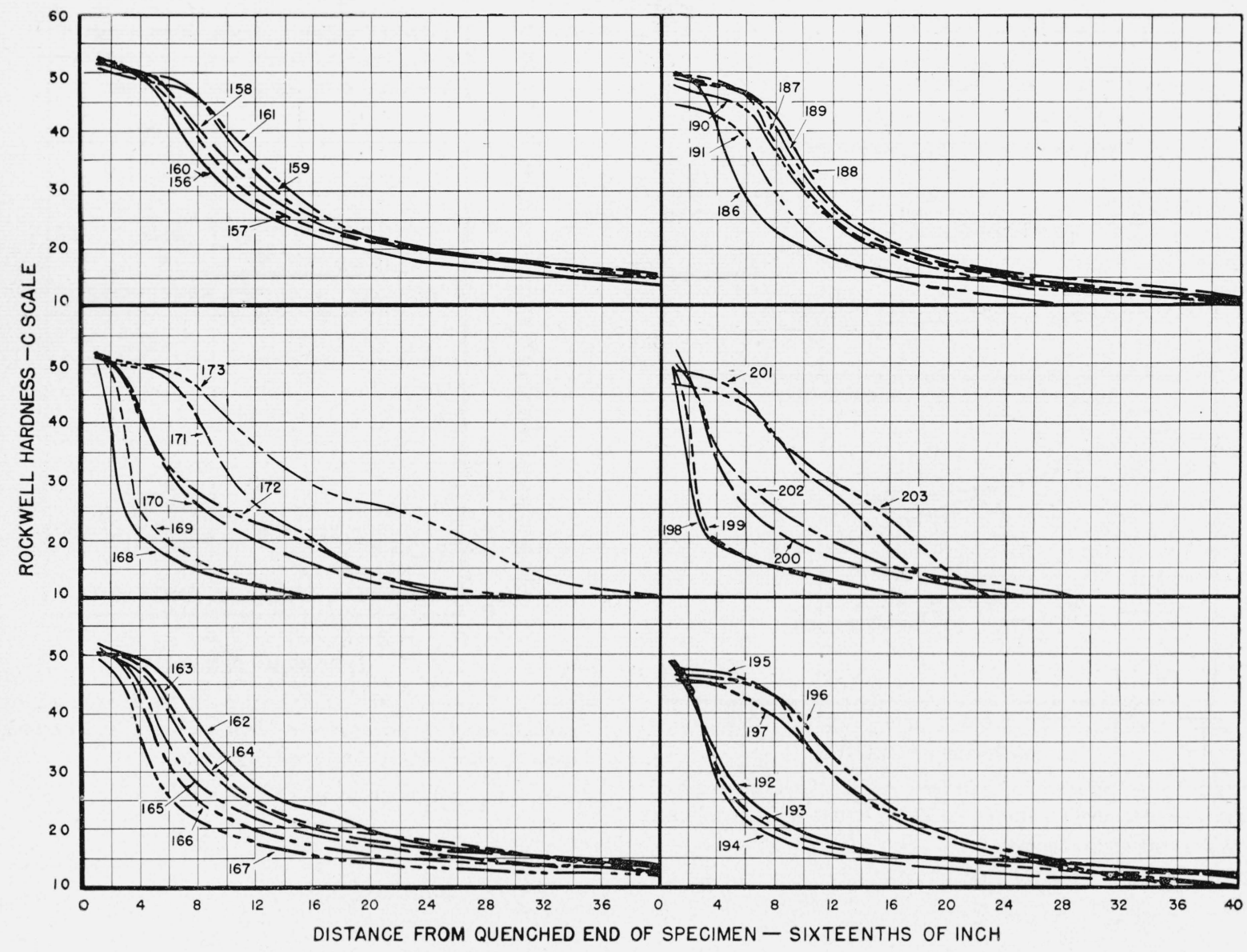

FiguRE 14.-Hardenability curves of experimental high-nitrogen steels containing 0.3 percent of carbon and 1.6 percent of manganese.

The chemical composition of the steels is given in table 3. Each heat was deoxidized with 0.10 percent of aluminum before adding the boron in the furnace with Ferroboron.

Specimens were normalized at $1,650^{\circ} \mathrm{F}$ and end-quenched from $1,575^{\circ} \mathrm{F}$.

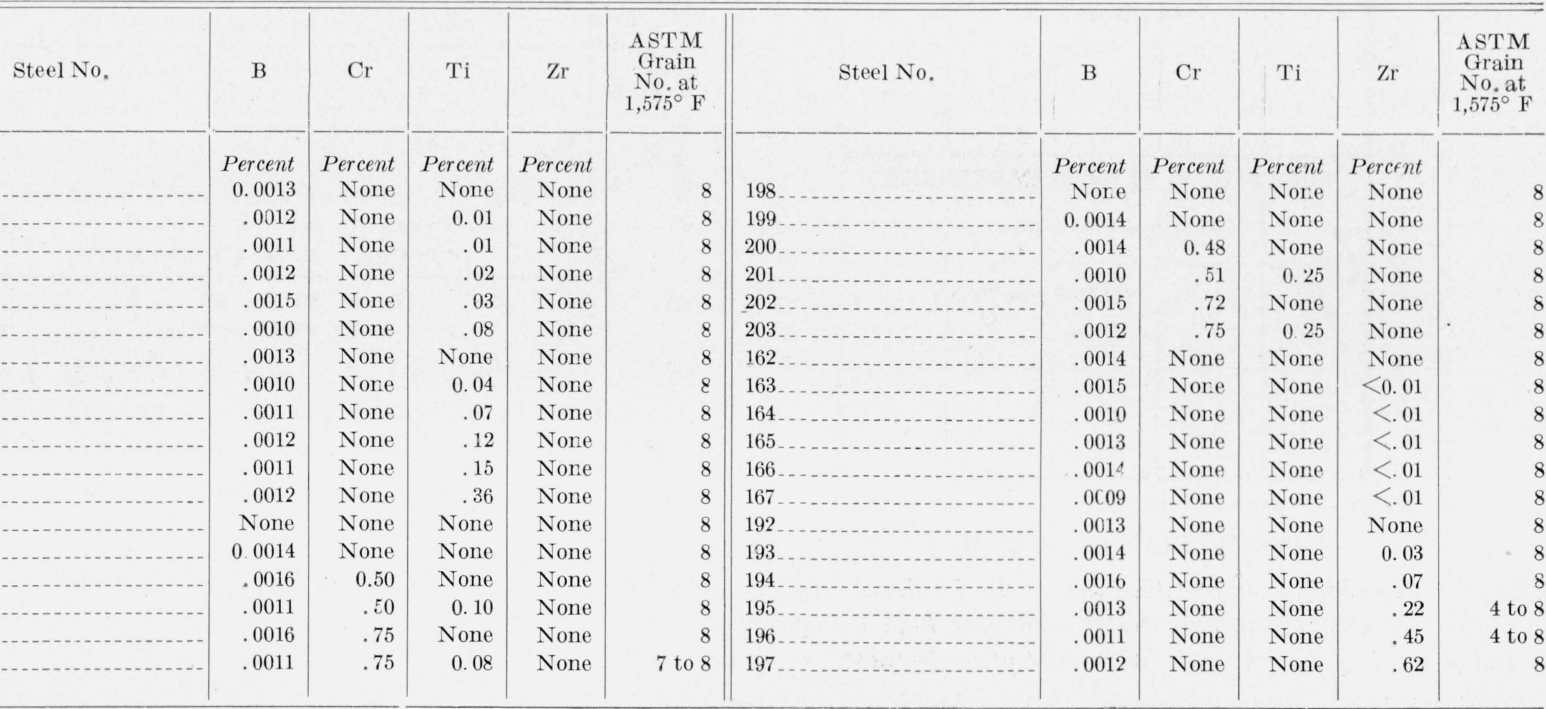




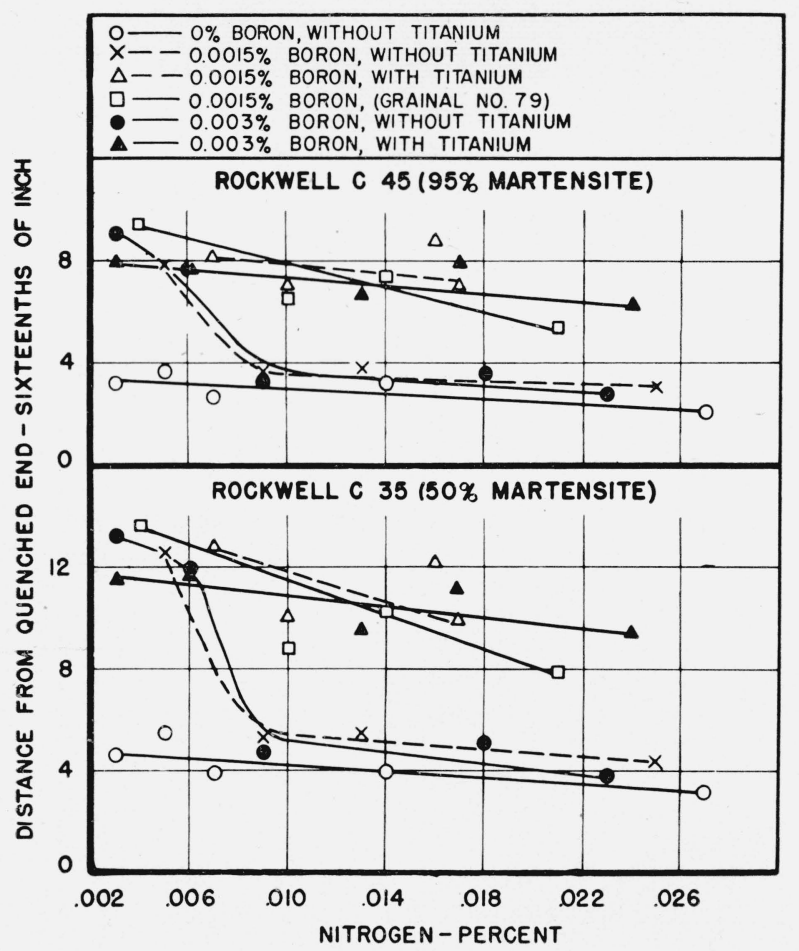

FIgure 15.-Influence of nitrogen on the hardenability of experimental steels containing 0.3 percent of carbon and 1.6 percent of manganese.

(Steels, 42,138 to 155 , and 180 to 185 , table 3 ).

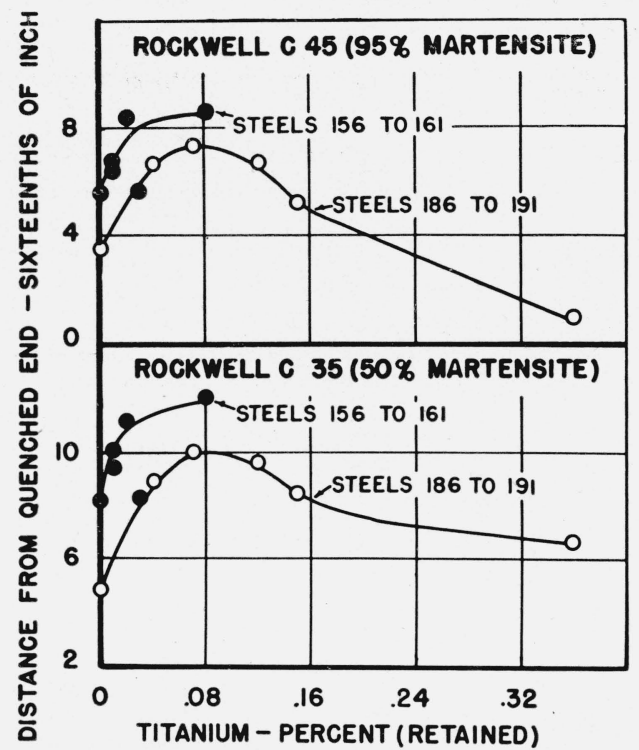

FIGURE 16.-Influence of titanium on the hardenability of boron-treated experimental steels containing high nitrogen, 0.3 percent of carbon, and 1.6 percent of manganese.

The chemical composition of the steels is given in table 3 .

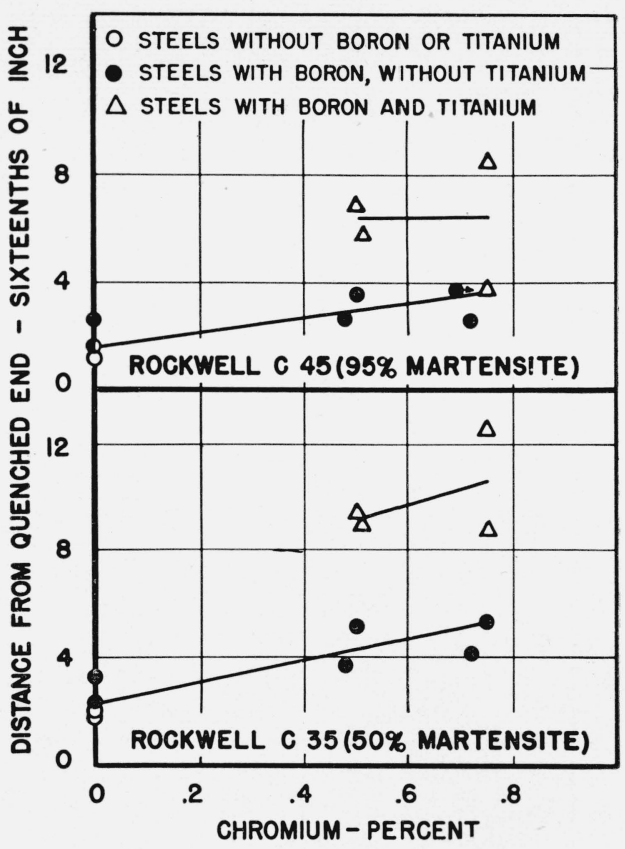

FIGURE 17.-Influence of chromium on the he rdenability of experimental steels containing high nitrogen, 0.3 percent of carbon, and 0.8 percent of manganese.

Steels 168 to 173 and 198 to 203 , table 3 .

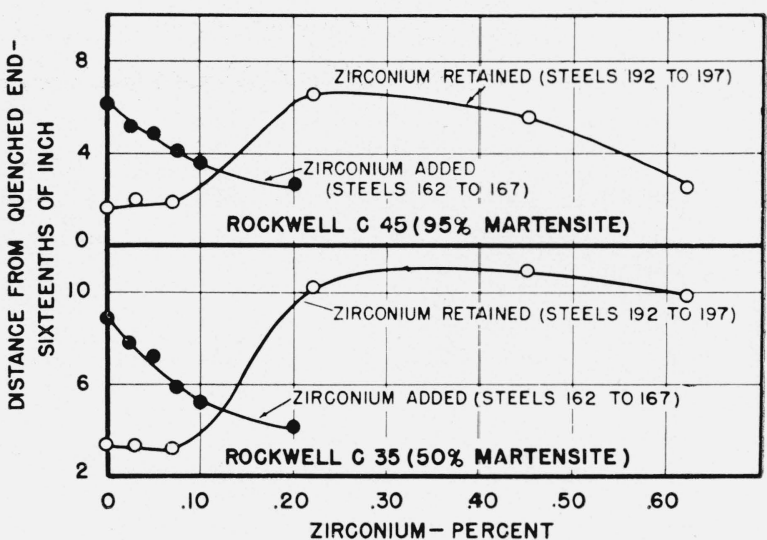

FIGURE 18.-Influence of zirconium on the hardenability of boron-treated experimental steels containing high nitrogen, 0.3 percent of carbon, and 1.6 percent of manganese.

The chemical composition of the steels is given in table 3 . 
enability of the two steels (162 and 192) not treated with zirconium, each containing about 0.0015 percent of boron might be due principally to a difference in carbon content (table 3). These results serve again to emphasize the interrelationship of carbon and boron and the hardenability of steels containing low to medium carbon.

A correlation of the nitrogen values (table 3) with hardenability show, in general, a fair agreement between the proportion of nitrogen soluble in 1 to 1 sulfuric acid and the hardenability of the boron steels with and without titanium. In the high-nitrogen steels prepared without titanium, or with zirconium, practically all the nitrogen was soluble in sulfuric acid, whereas in the steels containing titanium a large percentage of the nitrogen was usually insoluble. Whether the boron enhanced the hardenability of these steels without titanium or zirconium depended primarily upon the nitrogen content. If the values for soluble increasing hardenability. The exceptions were high acid-soluble nitrogen-boron steels without titanium (steels 156 and 162) and with titanium (steels 183, 157, 158, 159, and 187) that had fair to good hardenability. Microscopic examination showed the presence of titanium nitride, a compound insoluble in sulfuric acid at $350^{\circ} \mathrm{F}$, in all the steels treated with titanium.

For the high-nitrogen steels treated with zirconium, practically all the nitrogen was soluble in sulphuric acid. Microscopic examination, however, showed that zirconium nitride inclusions were formed with the addition of sufficient zirconium. These inclusions were insoluble in austenite at heat-treating temperatures but were soluble in sulfuric acid. It is clear, therefore, that nitrogen compounds may readily exist that are soluble in a given acid and insoluble in austenite at heat-treating temperatures. A close correlation in all cases between acid-soluble nitrogen and

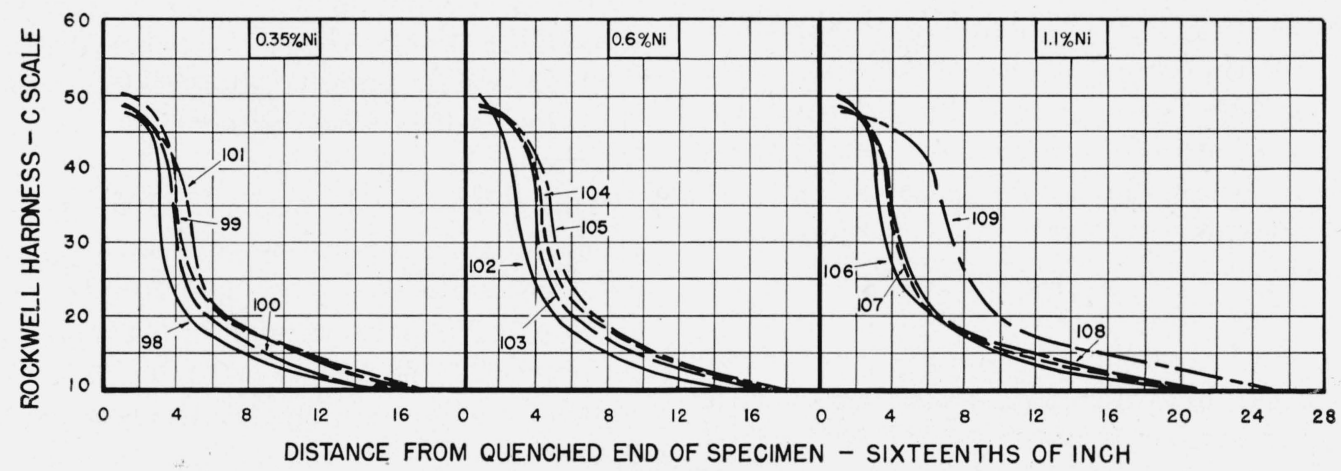

FIGURE 19.-Hardenability curves of experimental nickel steels containing 0.3 percent of carbon and 0.8 percent of manganese.

The chemical composition of the steels is given in table 4. Each heat was deoxidized with 0.10 percent of aluminum before adding the boron in the furnace with Ferroboron. Specimens were normalized at $1,650^{\circ} \mathrm{F}$ and end-quenched from $1,575^{\circ} \mathrm{F}$.

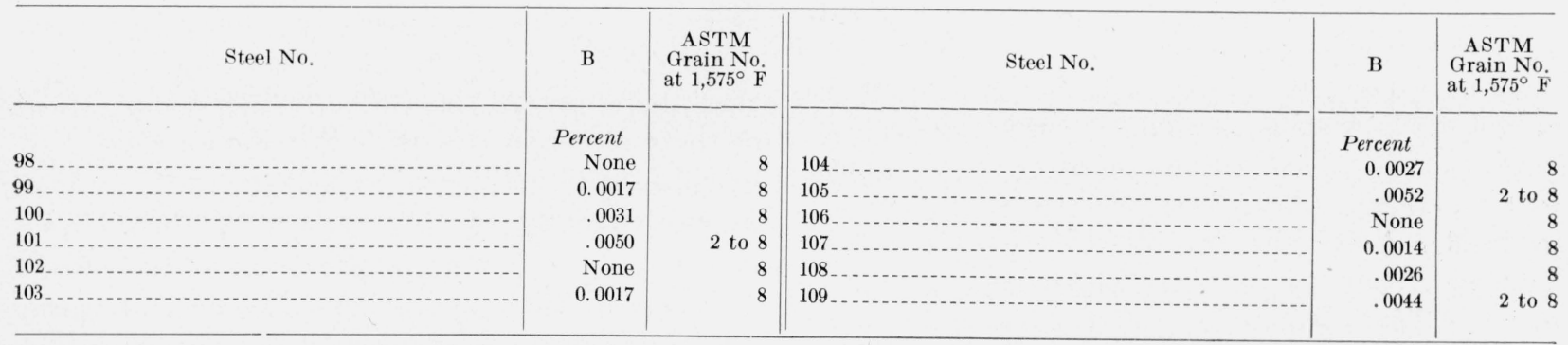

nitrogen were high, then the boron was usually relatively ineffective in improving the hardenability, and such a steel was comparatively shallow hardening. If sufficient titanium were added to combine with the nitrogen to form titanium nitride, then a large percentage of the nitrogen was insoluble in acid, and the boron was effective in hardenability of boron-treated steels should not be expected. It should also be pointed out that the additions of titanium or zirconium in excess of that required to react with the nitrogen in borontreated steels, may form carbides or enter into solution in the austenite and thus affect the hardenability. 


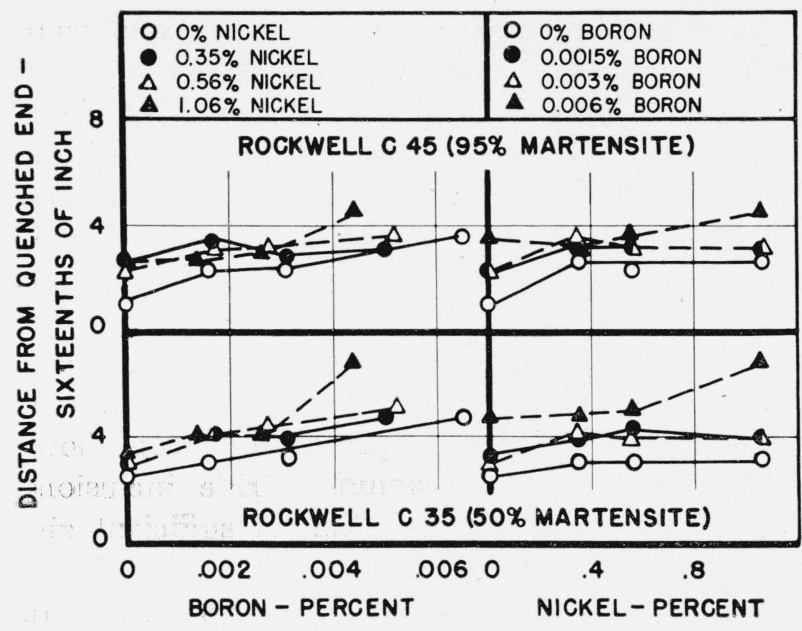

FIGURE 20.-Influence of boron and nickel on the hardenability of experimental steels containing 0.3 percent of carbon and 0.8 percent of manganese.

Steels 98 to 109 , table 4 .

The results of this study indicate that the role of titanium or zirconium in enhancing the hardenability of boron-treated steels containing high nitrogen is to act as a "fixer" for nitrogen by forming nitrides insoluble in austenite at hardening temperatures and thus to decrease the amount of soluble nitrogen available for reaction with boron. Both titanium and zirconium appear to have a greater affinity than boron for nitrogen, and the presence of sufficient amounts of either of these elements in high-nitrogen steels treated with boron has a desirable over-all effect on hardenability similar to that of a boron addition to a low-nitrogen steel.

4. Nickel.-The curves obtained from the results of the end-quench tests of the nickel steels listed in table 4 are given in figure 19 .

As is illustrated in figure 20, the hardenability of the steels without boron was only moderately improved by the additions of nickel ranging up to 1.1 percent. There was a slight improvement in hardenability due to boron, especially with 0.0044 percent, in the heat with 1.06 percent of nickel. The high-boron steel, however, contained some coarse grains at the hardening temperature of $1,575^{\circ} \mathrm{F}$, and this is a factor that tends to increase hardenability. The effectiveness of boron in improving the hardenability of steels with 0.3 percent of carbon and 0.90 percent of manganese, therefore, was not materially enhanced by the addition of nickel ranging up to 1.1 percent. All these steels were relatively shallow-hardening.

A comparison of the hardenability of the steel with 0.0065 percent of boron without nickel and the steel without boron but with 1.06 percent of nickel show that the increase in hardenability due to boron was somewhat greater than that produced by the nickel.

5. Chromium.-The curves obtained from the results of the end-quench tests of the chrornium steels listed in table 5 are given in figure 21 .

The hardenability of the steels, with and without chromium and with varying amounts of manganese was enhanced in all cases by the addition of boron either with Ferroboron or Grainal No. 79. The effectiveness of boron in improving hardenability, however, varied with the base composition of the heats and with the intensifiers used. Furthermore, the increase in this property due to boron was not always directly proportional to the amount added or retained in the steel. In some heats, the maximum effects were obtained with additions of 0.0015 or 0.003 percent, whereas in the other heats the steel with 0.006 percent of boron had the maximum hardenability.

The influence of boron additions made with either Ferroboron or Grainal No. 79 on the hardenability of steels with varying amounts of chromium and $0.8,1.25$, or 1.6 percent of manganese is shown in figures 22 and 23 . For the heats with 0.8 percent of manganese (fig. 22), the hardenability was a maximum, with the highest boron content in each of the heats with $0.0,0.25,0.5$, and 0.75 percent of chromium, but the increase in hardenability due to about 0.0015 percent of boron was equivalent to or greater than that produced by about 0.0030 percent. It should be again pointed out, that the grain size at the hardening temperature of these steels treated with Ferroboron tended to increase with boron content and the improvement in hardenability of the steels with the highest boron might be partially due to a grain-size effect. The hardenability of the 0.0065 percent of boron steel without chromium was of the same order of magnitude as that of the 0.75 percent of chromium steel without boron. That is, the increase in hardenability of the 0.8 percent manganese steels due to 0.0065 percent of boron was equivalent to that produced by about 0.75 percent of chromium. 


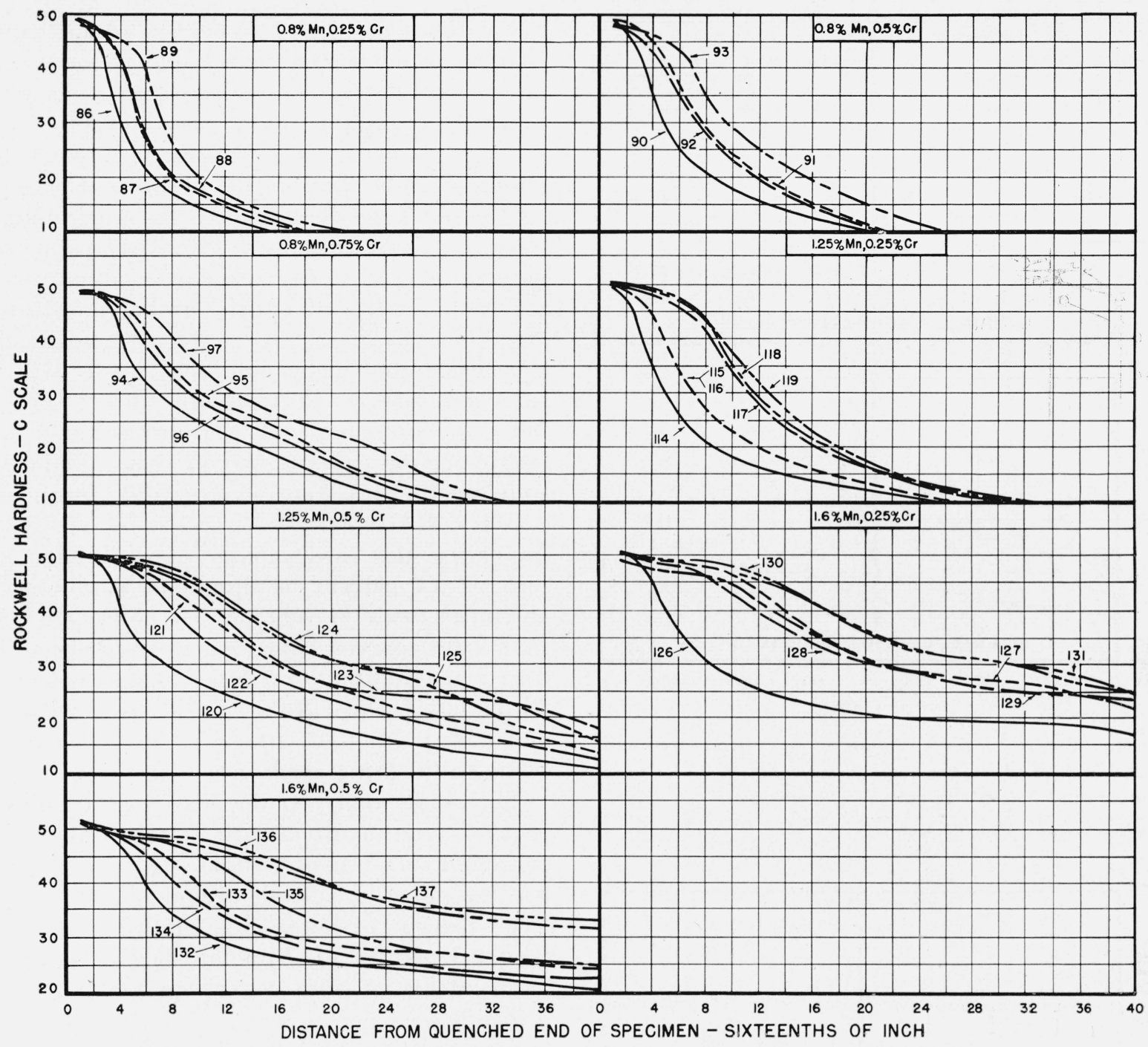

FIGURE 21.-Hardenability curves of experimental chromium steels containing 0.3 percent of carbon.

The chemical composition of the steels is given in table 5. Each heat was deoxidized with 0.10 percent of aluminum before adding the boron in the furnace with Ferroboron or in the ladle with Grainal No. 79. Specimens were normalized at $1,650^{\circ} \mathrm{F}$ and end-quenched from $1,575^{\circ} \mathrm{F}$.

\begin{tabular}{|c|c|c|c|c|c|c|c|}
\hline \multirow{2}{*}{$\begin{array}{l}\text { Steel } \\
\text { No. }\end{array}$} & \multicolumn{2}{|l|}{ Boron } & \multirow{2}{*}{$\begin{array}{l}\text { ASTM } \\
\text { Grain No. } \\
\text { at } 1,575^{\circ} \mathrm{F}\end{array}$} & \multirow{2}{*}{$\begin{array}{l}\text { Steel } \\
\text { No. }\end{array}$} & \multicolumn{2}{|l|}{ Boron } & \multirow{2}{*}{$\begin{array}{c}\text { ASTM } \\
\text { Grain No. } \\
\text { at } 1,575^{\circ} \mathrm{F}\end{array}$} \\
\hline & Agent & Amount & & & Agent & Amount & \\
\hline 86 & None ........ & $\begin{array}{l}\text { Percent } \\
\text { None }\end{array}$ & 8 & 120 & None $\ldots . . . . . . . .$. & $\begin{array}{l}\text { Percent } \\
\text { None }\end{array}$ & 8 \\
\hline 87 & Ferroboron ... & 0.0018 & 8 & 121 & Ferroboron & 0.0014 & 8 \\
\hline 88 & do _._. & .0029 & 8 & 122 & _._. do . . . & .0030 & 7 to 8 \\
\hline 89 & do & .0018 & 3 to 8 & 123 & _... do & .0051 & 4 to 8 \\
\hline 90 & None ............. & None & 8 & 124 & Grainal No. 79 & .0011 & 8 \\
\hline 91 & Ferroboron .............. & 0.0013 & 8 & 125 & _... do . . . . & .0038 & 8 \\
\hline 92 & do do . & .0024 & 8 & 126 & None & None & 7 to 8 \\
\hline 93 & _. do . _. _ & .0050 & 4 to 8 & 127 & Ferroboron $\ldots . . . .$. & 0.0016 & 7 to 8 \\
\hline 94 & None ............... & None & 8 & 128 & _... do . . . & .0031 & 6 to 8 \\
\hline 95 & Ferroboron & 0.0015 & 8 & 129 & (..... do . .......... & .0049 & 4 to 8 \\
\hline 96 & do & .0027 & 7 to 8 & 130 & Grainal No. 79 & .0009 & 7 to 8 \\
\hline 97 & do & .0048 & 6 to 8 & 131 & (..... do do . . & .0039 & 7 to 8 \\
\hline 114 & None & None & 8 & 132 & None & None & 7 to 8 \\
\hline 115 & Ferroboron & 0.0017 & 8 & 133 & Ferroboron & 0.0016 & 6 to 8 \\
\hline 116 & _ do & .0029 & 8 & 134 & (.... do & .0028 & 6 to 8 \\
\hline 117 & - do & .0057 & 4 to 8 & 135 & . & .0057 & 4 to 7 \\
\hline 118 & Grainal No. 79 & .0011 & 8 & 136 & Grainal No. 79 & .0011 & 8 \\
\hline 119 & do & .6033 & 8 & 137 & $\mid$ & .0041 & 8 \\
\hline
\end{tabular}




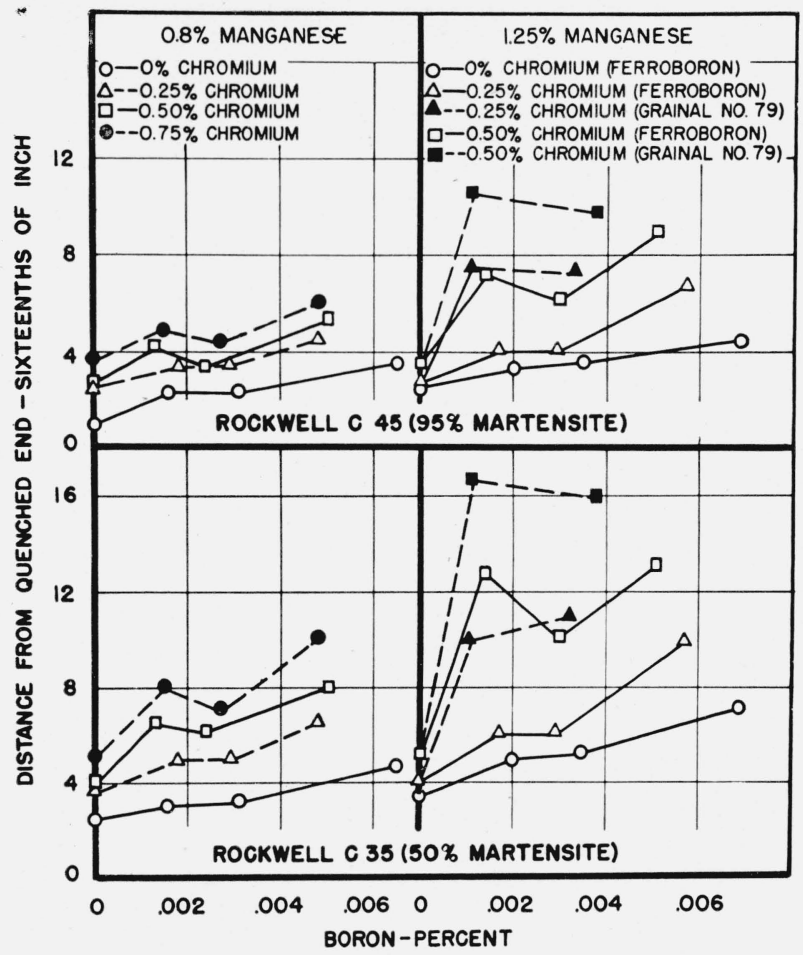

Figure 22.-Influence of boron on the hardenability of experimental chromium steels containing 0.3 percent of carbon and 0.8 or 1.25 percent of manganese.

Steels 86 to 97 and 114 to 125 , table 5 .

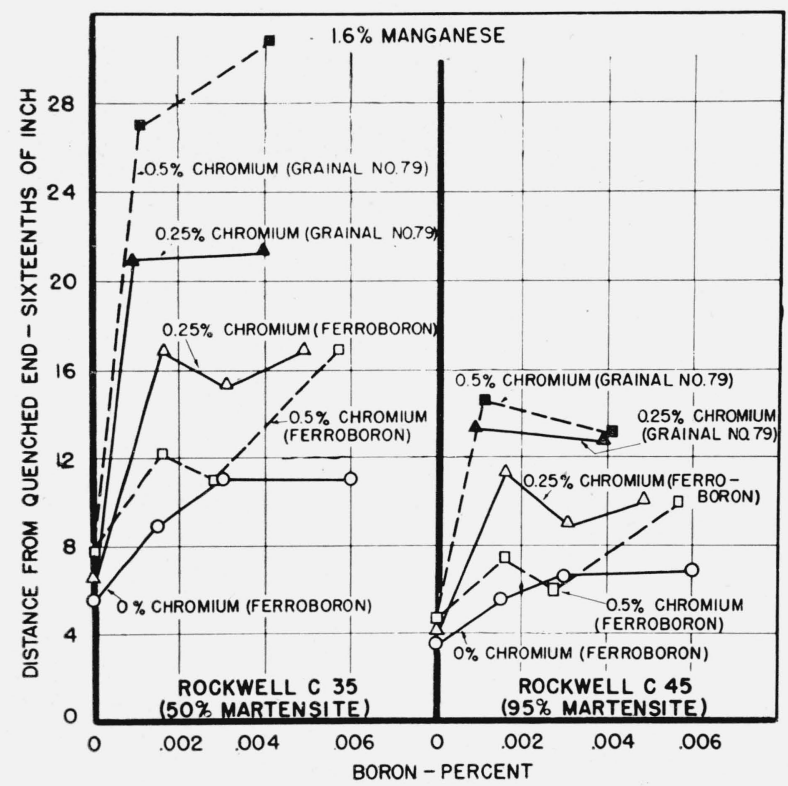

Figure 23.-Influence of boron on the hardenability of experimental chromium steels containing 0.3 percent of carbon and 1.6 percent of manganese.

Steels 126 to 137 , table 5 .
For the heats with 1.25 percent of manganese, (fig. 22) the increase in hardenability due to boron additions with Ferroboron was again a maximum in the steel containing the highest boron from each of the two heats with 0.0 and 0.25 percent of chromium, but the addition of about 0.0015 percent of boron resulted in about the same improvement as 0.003 percent. With the 0.5 percent chromium steels, the addition of about 0.0015 percent of boron with either Ferroboron or Grainal No. 79 was as effective in increasing hardenability as considerably higher additions made with the same intensifiers. Furthermore, a lower hardenability was obtained with 0.003 percent than with 0.0015 or 0.005 percent of boron when the additions were made with Ferroboron. The addition of boron with Grainal No. 79 was more effective in improving the hardenability of each heat with 0.25 or 0.5 percent of chromium than was the treatment with Ferroboron. A noteworthy feature is the marked improvement in hardenability due to the addition of 0.001 to 0.0015 percent of boron with Grainal No. 79 to the steels with 0.25 and 0.50 percent of chromium and with Ferroboron to the latter steel.

The hardenability of the steel with 0.0069 percent of boron (addition with Ferroboron) without chromium was greater than that of the 0.50 percent chromium steel without boron. Thus, 0.007 percent of boron was equivalent to more than 0.5 percent of chromium in increasing the hardenability of steels containing 1.25 percent of manganese.

For the heats with 1.6 percent of manganese (fig. 23), the hardenability of the steels without chromium increased with increase in boron from 0.0 to 0.003 percent then remained constant with further increase in boron (additions made with Ferroboron). The increase in hardenability due to similar amounts of boron (additions with Ferroboron) was greater for the 0.25 percent chromium steel than for the steel with 0.50 percent. Since the hardenability of low alloy steels usually increases with the chromium content, this effect of small additions of boron made with Ferroboron on these 1.6 percent manganese steels with varying amounts of chromium was unexpected. End-quench tests were repeated with specimens of each of the steels containing about 0.0015 percent of boron and spectrographic analyses for chromium and manganese were made on the end- 
quenched bars from all the steels comprising the two heats. The results of the original and check tests agreed closely. Microscopic examination showed no evidence of free carbides in the Jominy bars after the end-quench test of either of the two steels. Deoxidation practice and additions of Ferroboron were similar for both heats and the percentages of the various elements (table 5) were quite similar in all these steels (except for chromium content). Furthermore, when comparisons are made on the basis of the results reproduced in figure 23, the hardenability of the steels with 0.003 percent of boron was not improved by a change in chromium from 0.0 to 0.50 percent. For the steels treated with Grainal No. 79 , the hardenability of the 0.50 percent chromium steels was somewhat greater than that of 0.25 percent. However, the retention of approximately 0.001 percent of boron was about as effective as 0.004 percent.

The slope of the curves of figures 22 and 23 show that the effectiveness of boron in improving hardenability was somewhat enhanced in the 0.8 percent manganese steels by the presence of chromium and considerably enhanced by its presence in the steels containing low additions of boron (especially with Grainal No. 79) and 1.25 or 1.6 percent of manganese. In general, the effectiveness of boron increased with increase in both chromium and manganese and boron additions with Grainal No. 79 were more effective than with Ferroboron.

6. Nickel-Chromium.-The curves obtained from the results of the end-quench tests of the nickel-chromium steels listed in table 6 are given in figure 24 .

As already pointed out, the standard endquench test is not well suited for determining the hardenability of steels that harden throughout in $3 / 4$-in. or larger rounds by cooling in still air, such as the present steels with 1.6 percent of manganese. It is obvious from the results of the end-quench test that comparisons of the hardenability on the basis of the distances from the quenched end of the bars corresponding to a hardness value of Rockwell C 35 (50\% of martensite) cannot be made with all the 1.6 percent of manganese steels. However, a comparison of these steels, as usual, can be made of the distances corresponding to Rockwell C 45 (95\% of martensite).

The effectiveness of boron in improving the hardenability of the steels with 0.5 percent of chromium and varying amounts of nickel and manganese varied with the chemical composition of the intensifier and the amount of boron retained. Improvement, in some cases insignificent, was obtained by the additions of boron, but the increase in hardenability due to similar amounts was usually considerably more marked when the additions were made with Grainal No. 79 than with Ferroboron. Furthermore, a maximum was obtained for the steel of each heat with the smallest addition $(0.0007 \%$ added, 0.0005 to $0.0010 \%$ retained) of Ferroboron whereas the increase in hardenability from the treatment with Grainal No. 79 was not so critically dependent upon the final boron content (fig. 25).

The hardenability increased slightly with a change in nickel from 0.5 to 1.0 percent in these 0.5 percent of chromium, 0.8 or 1.6 percent manganese steels without boron and also in the 0.8 percent manganese steels treated alike with Ferroboron. However, a decrease in hardenability was obtained in the steels with 1.6 percent of manganese and about 0.003 to 0.006 percent of boron (additions with Ferroboron) with a change in nickel from 0.5 to 1.0 percent. The results of the tests with the 1.6 percent manganese steels agree closely with those obtained on 1.6 percent of manganese, 0.25 and 0.5 percent chromium steels without nickel (fig. 23), in that boron additions were considerably more effective when made with Grainal No. 79 than with Ferroboron; and treatments with Grainal for about 0.001 percent retained boron were approximately as effective as higher amounts. However, the relatively low values for hardenability obtained with some of the present steels treated with Ferroboron was unexpected, especially in view of the results reported for similar steels by Lorig, Rosenthal, and Udy [22]. They found that additions of 0.0015 or 0.003 percent of boron with Ferroboron or 0.002 percent of boron with Grainal No. 79 were about equally effective in increasing the hardenability of wrought steels containing 0.5 percent of chromium, 0.5 percent of nickel with and without molybdenum, and that the addition of 0.006 percent of boron as Ferroboron produced slightly, but noticeably less, hardenability than the other additions.

As already pointed out, the effectiveness of boron in increasing hardenability varied with the nitrogen content of the steels investigated. In high 


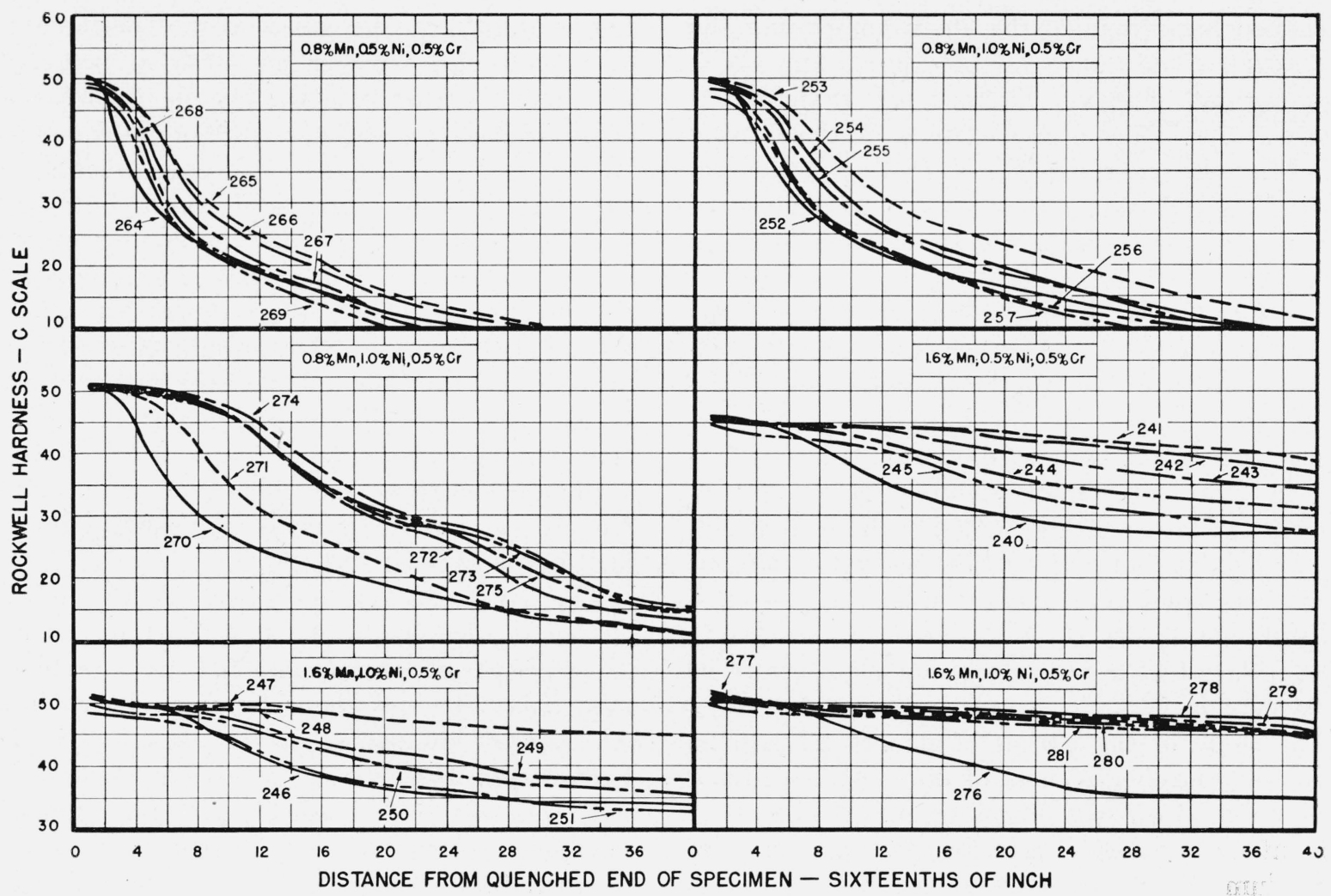

FIGURE 24.-Hardenability curves of experimental nickel-chromium steels containing 0.3 percent of carbon.

The chemical composition of the steels is given in table 6 . Each heat was deoxidized with 0.10 percent of aluminum before adding the boron in the furnace with Ferroboron or Grainal No. 79. Specimens were normalized at $1,675^{\circ} \mathrm{F}$ and end-quenched from $1,600^{\circ} \mathrm{F}$.

\begin{tabular}{|c|c|c|c|c|c|c|c|}
\hline \multirow{2}{*}{$\begin{array}{l}\text { Steel } \\
\text { No. }\end{array}$} & \multicolumn{2}{|l|}{ Boron } & \multirow{2}{*}{$\begin{array}{l}\text { ASTM } \\
\text { Grain No. } \\
\text { at } 1,600^{\circ} \mathrm{F}\end{array}$} & \multirow{2}{*}{$\begin{array}{l}\text { Steel } \\
\text { No. }\end{array}$} & \multicolumn{2}{|l|}{ Boron } & \multirow{2}{*}{$\begin{array}{l}\text { ASTM } \\
\text { Grain No. } \\
\text { at } 1,600^{\circ} \mathrm{F}\end{array}$} \\
\hline & Agent & Amount & & & Agent & Amount & \\
\hline 264 & None ........... & $\begin{array}{l}\text { Percent } \\
\text { None }\end{array}$ & 8 & 240 & None.... & $\begin{array}{l}\text { Percent } \\
\text { None }\end{array}$ & 7 \\
\hline 265 & Ferrohoron ........ & 0.0008 & 8 & 241 & Ferroboron ....... & 0.0009 & 7 \\
\hline 266 & - do & .0009 & 8 & 242 & ..... do _. . . . . & .0010 & 7 \\
\hline $2 f i 7$ & - do $_{2}$ & .0014 & 8 & 243 & _.... do . . . . . . & .0014 & 7 \\
\hline $26 \mathrm{i}$ & - & .0028 & 8 & 244 & _... do . . . . & .0029 & 7 \\
\hline 269 & _... do do & .0053 & 8 & 245 & $\ldots$ do _....... & $.00 €: 1$ & 7 \\
\hline 252 & None & None & 8 & 245 & 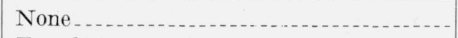 & None & 7 to 8 \\
\hline 253 & Ferroboron & 0.0010 & 8 & 247 & Ferroboron & 00011 & 7 \\
\hline 254 & - do & .0014 & 8 & 248 & .... do . . . . . . & .0008 & 7 \\
\hline 255 & _._. de de & .0018 & 8 & 249 & - & .0017 & 7 \\
\hline 256 & - do do & .0031 & 8 & 250 & - & .0031 & 7 \\
\hline 257 & 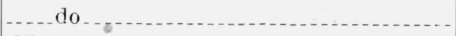 & .0050 & 8 & 251 & ..... do . . . . . . & .0063 & 7 \\
\hline 270 & None & None & 8 & 276 & None & None & 7 \\
\hline 271 & Grainal No. 79 & 0.0005 & 8 & 277 & Grainal No. $79 \ldots \ldots$ & 0.0005 & 7 \\
\hline 272 & - do & .0005 & 8 & 278 & (.... do . . . & .0006 & 7 \\
\hline 273 & - & .0008 & 7 to 8 & 279 & ..... do . . . . . . & .0014 & 7 \\
\hline 274 & - & .0015 & 8 & 280 & _... do . . . & .0018 & 7 to 8 \\
\hline 275 & - do & .0026 & 8 & 281 & do & .0030 & 7 to 8 \\
\hline
\end{tabular}




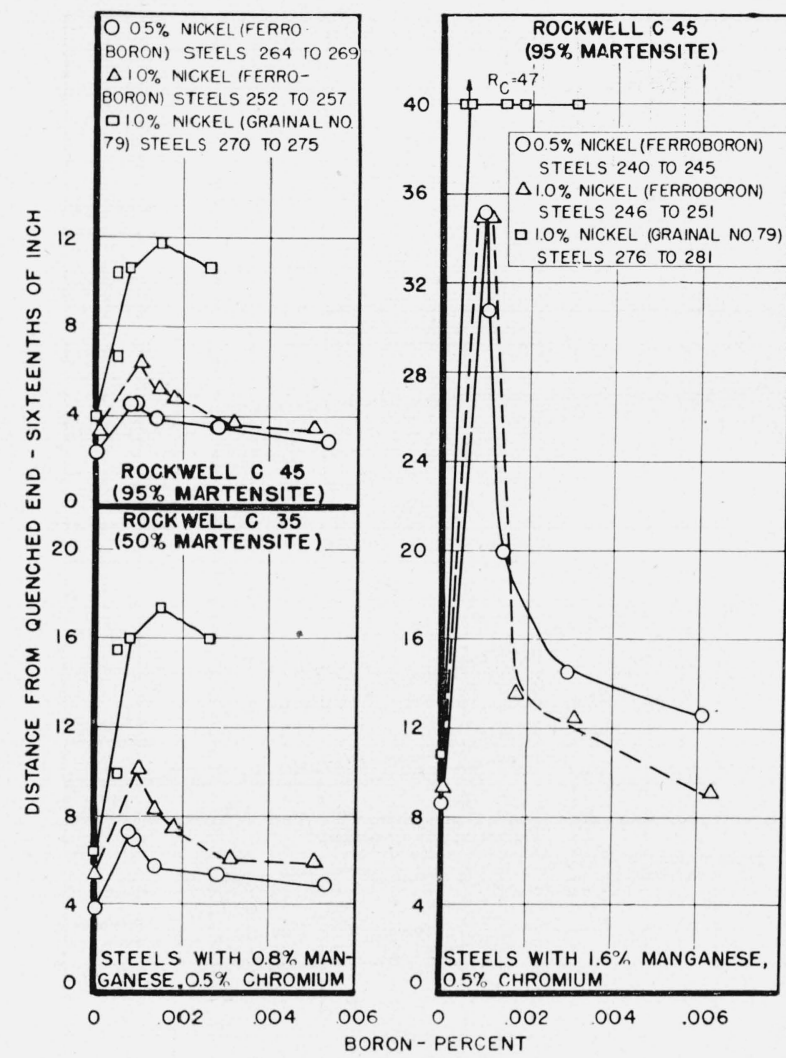

Figure 25.-Influence of boron on the hardenability of experimental nickel-chromium steels containing 0.3 percent of carbon.

The chemical composition of the steels is given in table 6 .

nitrogen steels, without titanium or zirconium, additions of 0.0015 or 0.003 percent of boron with Ferroboron were usually ineffective in increasing hardenability, but the boron effect was retained by including sufficient amounts of either titanium or zirconium to react with most of the nitrogen and thus form nitride inclusions that were insoluble in austenite at the heat-treating temperatures used. The results of the determinations for nitrogen of the steels listed in table 6 show that some of the values were on the high side of the range normally obtained with the induction heats. In these aluminum-killed steels treated with Ferroboron, all the nitrogen was soluble in 1 to 1 or stronger sulfuric acid, and presumably a large percentage was available for reacting with the boron at the hardening temperature, whereas in the aluminumkilled steels treated with Grainal No. 79, a large portion of the nitrogen at heat-treating temperatures existed as titanium or zirconium inclusions. The hardenability of the latter steels, with low acid-soluble nitrogen, was considerably enhanced by boron. However, no very definite correlation appeared to have existed between total nitrogen and hardenability. For example, the trend was for the hardenability of the steels comprising heats 10101 and 10102 that were treated with Ferroboron, to decrease with a decrease in nitrogen values, a condition that is the reverse of that ordinarily expected from the results previously described.

Lorig, and coworkers [22] found that incomplete deoxidation had an adverse effect on the hardenability of boron-treated steels. Insufficiently deoxidized heats often showed complete obliteration or irregularity in the hardenability effects due to the boron additions, and they reported that the low hardenability values of such heats were in no way connected with the analysis.

Since the Grainal No. 79 contained about 13 percent of aluminum and other elements (titanium and zirconium) that are effective as deoxidizers, the steels processed from heats treated with this intensifier should be somewhat more thoroughly deoxidized than those deoxidized solely with 0.10 percent of aluminum. However, it seems reasonable to expect that the addition of 0.10 percent of aluminum to an induction melt just prior to treating with Ferroboron would be ample for deoxidation of the heat and thereby prevent undue loss of boron or a change of its condition into a form incapable of exerting its full effect on hardenability. Thus the observed irregularities in the hardenability of these boron treated nickelchromium steels and in some of the following chromium-molybdenum steels cannot be entirely attributed to their nitrogen content or to the deoxidizing practice.

7. Chromium-molybdenum.-The curves obtained from the results of the end-quench tests of the chromium-molybdenum steels listed in table 7 are given in figure 26. The effect of boron on hardenability, based upon the penetration in the end-quenched bar for hardness values of Rockwell C 35 and C 45 is shown in figures 27 and 28 .

For the chromium-molybdenum steels comprising the two heats containing 0.8 percent of manganese (fig. 27) the hardenability was increased somewhat by relatively small additions of boron with Ferroboron and with all additions of Grainal No. 79. The improvement was insignificant, however, with the higher addition of boron with 


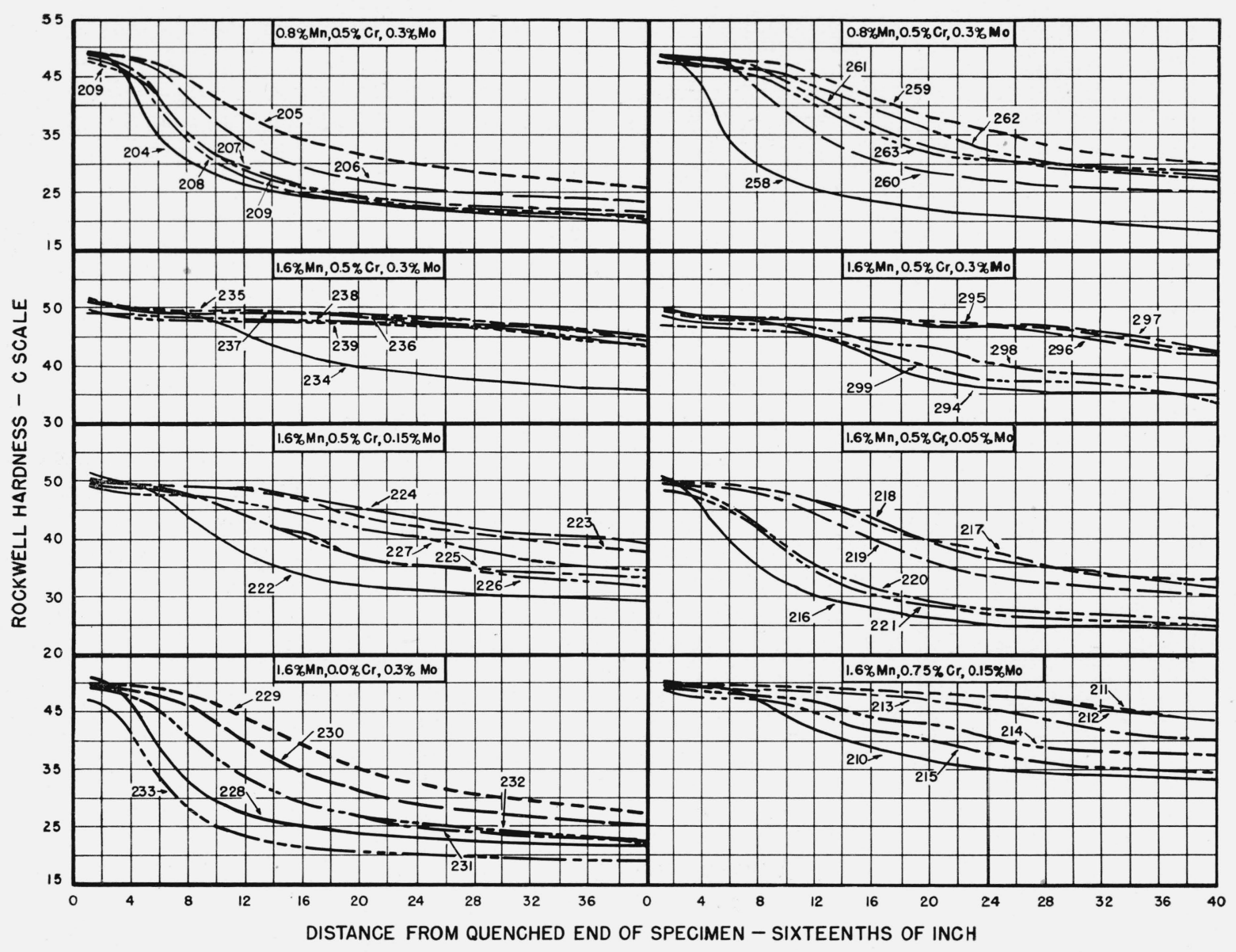

FIGURE 26.-Hardenability curves of experimental chromium-molybdenum steels containing 0.3 percent of carbon and 0.8 or 1.6 percent of manganese.

The chemical composition of the steels is given in table 7 . Each heat was deoxidized with 0.10 percent of aluminum before adding the boron in the furnace with Ferroboron or Grainal No. 79. Specimens were normalized at $1,675^{\circ} \mathrm{F}$ and end-quenched from $1,600^{\circ} \mathrm{F}$.

\begin{tabular}{|c|c|c|c|c|c|c|c|}
\hline \multirow{2}{*}{$\begin{array}{l}\text { Steel } \\
\text { No. }\end{array}$} & \multicolumn{2}{|l|}{ Boron } & \multirow{2}{*}{$\begin{array}{c}\text { ASTM } \\
\text { Grain No. } \\
\text { at } 1,600^{\circ} \mathrm{F}\end{array}$} & \multirow{2}{*}{$\begin{array}{c}\text { Steel } \\
\text { No. }\end{array}$} & \multicolumn{2}{|l|}{ Boron } & \multirow{2}{*}{$\begin{array}{c}\text { ASTM } \\
\text { Grain No. } \\
\text { at } 1,600^{\circ} \mathrm{F}\end{array}$} \\
\hline & Agent & Amount & & & Agent & Amount & \\
\hline 204 & None.... & $\begin{array}{l}\text { Percent } \\
\text { None }\end{array}$ & 7 to 8 & 222 & None. - & $\begin{array}{l}\text { Percent } \\
\text { None }\end{array}$ & 7 to 8 \\
\hline 205 & Ferroboron ....... & 0.0005 & 7 to 8 & 223 & Ferroboron .... & 0.0005 & 6 to 7 \\
\hline 206 & _... do . . . . & .0009 & 7 to 8 & 224 & _.... do _ . . . & .0009 & 6 to 7 \\
\hline 207 & $\ldots$ do ...... & .0012 & 7 to 8 & 225 & $\ldots$..... do _... & .0013 & 6 to 7 \\
\hline 208 & _._. do $d 0 \ldots$ & .0023 & 7 to 8 & 226 & _.... do . . . . & .0025 & 6 to 8 \\
\hline 209 & _ do _ _ _ & .0048 & 7 to 8 & 227 & $\ldots$ do $\ldots . .$. & .0049 & 6 to 7 \\
\hline 258 & None .......... & None & 8 & 216 & None . . . . . . & .0000 & 7 to 8 \\
\hline 259 & Grainal No. 79 & 0.0005 & 7 & 217 & Ferroboron ..... & .0005 & 7 to 8 \\
\hline 260 & _... do & .0005 & 7 to 8 & 218 & ..... do . .... & .0009 & 7 to 8 \\
\hline 261 & - do & .0008 & 6 to 8 & 219 & $\ldots$..... do _........ & .0012 & 7 to 8 \\
\hline 262 & do do & .0013 & 7 to 8 & 220 & ..... do . ........ & .0024 & 7 to 8 \\
\hline 263 & .... do . . . . . & .0030 & 7 to 8 & 221 & Ferroboron & .0048 & 7 to 8 \\
\hline 234 & None ............ & .0000 & 7 to 8 & 228 & None & None & 7 to 8 \\
\hline 235 & Grainal No, 79 & .0003 & 6 to 7 & 229 & Ferroboron & 0.0005 & 6 to 7 \\
\hline 236 & ..... do . ......... & .0004 & 6 to 7 & 230 & 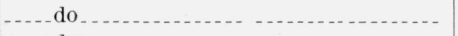 & .0011 & 6 to 7 \\
\hline 237 & - do & .0007 & 6 to 7 & 231 & _.... do & .0013 & 6 to 7 \\
\hline 238 & - do & .0013 & 6 to 7 & 232 & $\ldots$..... do . . .... & .0025 & 6 to 7 \\
\hline 239 & ....... do & .0026 & 7 & 233 & _._. do & .0047 & 7 to 8 \\
\hline 294 & None & None & 7 to 8 & 210 & None & None & 7 \\
\hline 295 & Ferroboron & 0.0003 & 7 & 211 & Ferroboron .... & 0.0006 & 6 to 7 \\
\hline 296 & ..... do . ....... & .0010 & 6 to 7 & 212 & ..... do . . . . . & .0009 & 6 to 7 \\
\hline 297 & .... do ......... & .0014 & 6 to 7 & 213 & - do & .0012 & 6 to 7 \\
\hline 298 & - & .0026 & 6 to 7 & 214 & -.... do . ....... & .0024 & 6 to 7 \\
\hline 299 & 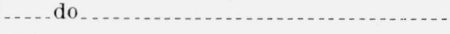 & .0048 & 6 to 7 & 215 & _. do _ _. & .0043 & 6 to 7 \\
\hline
\end{tabular}




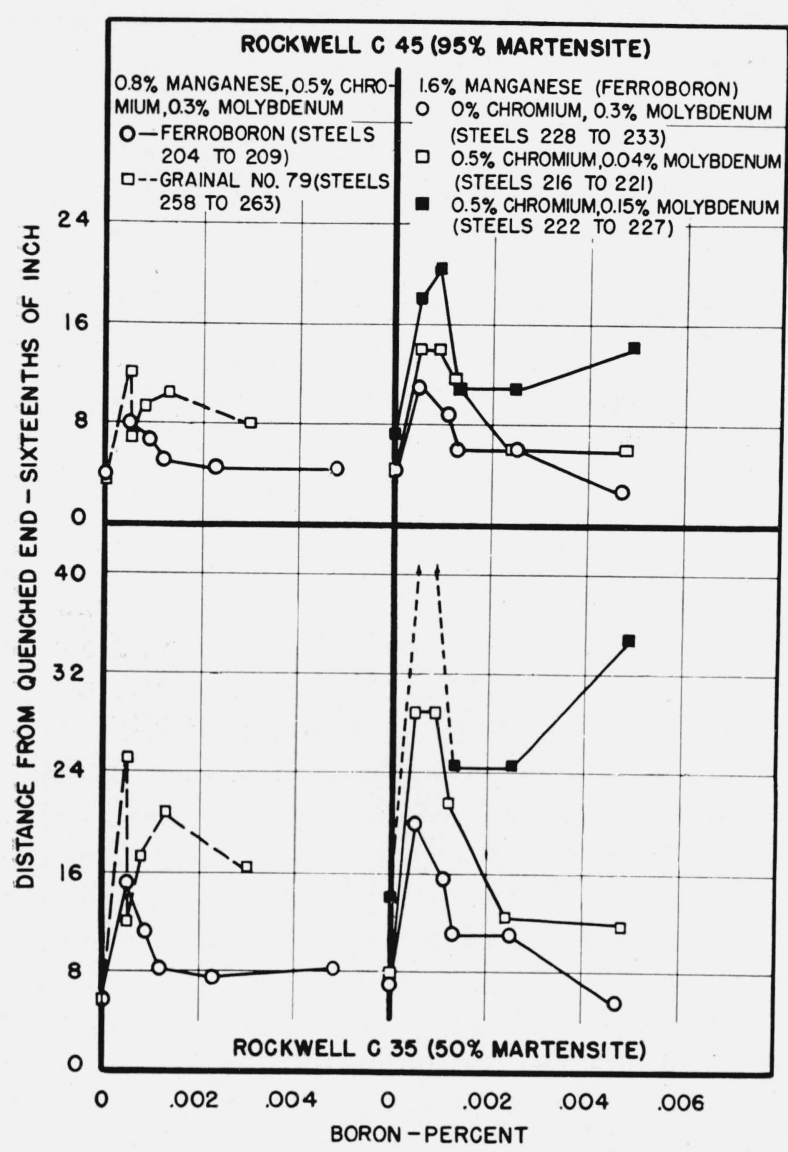

Figure 27.-Influence of boron on the hardenability of experimental chromium-molybdenum steels containing 0.3 percent of carbon and 0.8 or 1.6 percent of manganese.

The chemical composition of the steels is given in table 7 .

Ferroboron, and there was a wide variation in the hardenability of two steels (259 and 260) from the same heat, each treated with Grainal No. 79 and with 0.0005 percent of retained boron. The variation in hardenability of these two steels of similar chemical composition was equivalent to or greater than the improvement obtained in many cases by boron.

The chromium-molybdenum steels comprising some of the heats with 1.6 percent of manganese were deep-hardening, similar to some of the nickelchromium steels already described. As is illustrated in figures 27 and 28 , the hardenability attained a maximum in the steel from each heat with relatively low boron (usually less than $0.001 \%$ ) when the additions were made with either Grainal No. 79 or Ferroboron. The hardenability of three of these heats, however, was not materially improved by the treatment with Ferro-

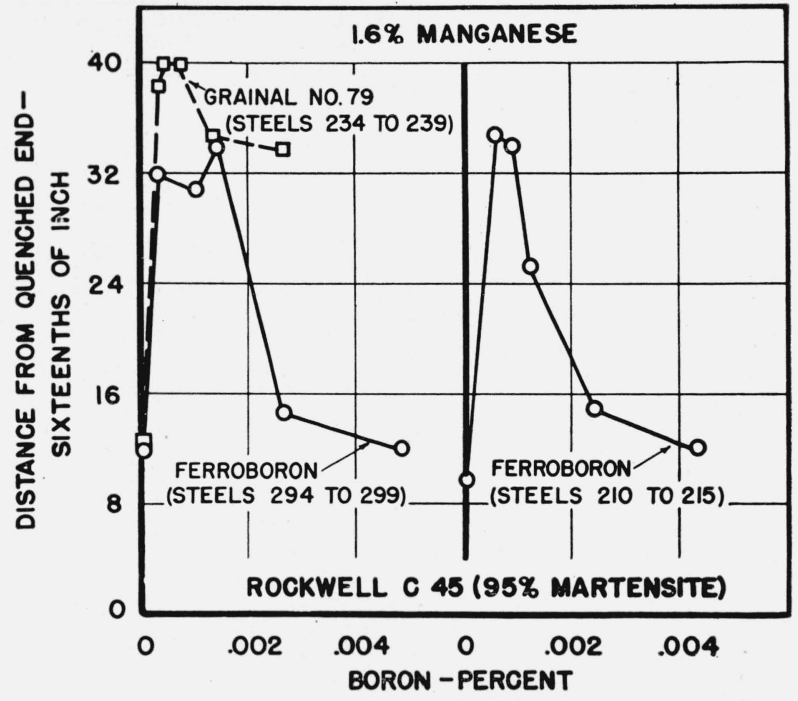

Figure 28.-Influence of boron on the hardenability of experimental chromium-molybdenum steels containing 0.3 percent of carbon and 1.6 percent of manganese.

The chemical composition of the steels is given in table 7 .

boron for the highest boron content; in one case, the hardenability of the boron-treated steel was inferior to that of the base steel without boron (steels 233 and 228, respectively).

Thus, the effectiveness of boron in improving the hardenability of these steels varied with the base composition of the steels, composition of the intensifiers, and amount of boron retained. In general, the relatively low additions were more effective than the high, and the hardenability of the steels treated with Grainal No. 79 was superior to that of the steels of similar base composition treated with Ferroboron.

The influence of molybdenum, chromium, and manganese on the hardenability (based upon the penetration for a hardness value of Rockwell C 45) is shown in figure 29. The hardenability of the steels, with and without boron, increased with increase in molybdenum, chromium or manganese. These data also show the wide variation in hardenability of the steels from each of the several heats treated with varying amounts of boron. For steels treated with Ferroboron, the minimum value for hardenability was of the same order of magnitude as that of the base steel from the same heat. However, the maximum improvement in hardenability due to the addition of boron increased with the amounts of molybdenum, chromium, or manganese. This indicates that 


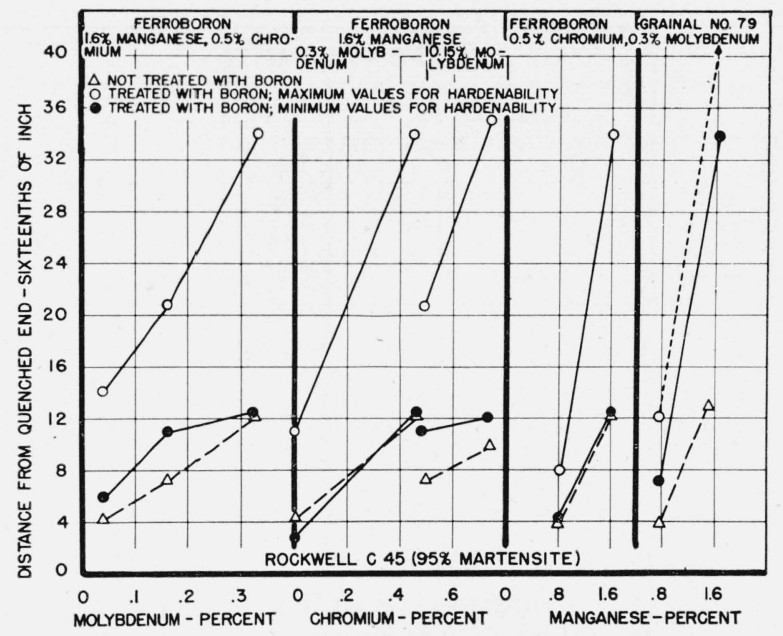

FIGURE 29.-Relation of molybdenum, chromium, and manganese to the hardenability of experimental steels containing 0.3 percent of carbon.

Steels 204 to 239,258 to 263 , and 294 to 299 , table 7 .

the effectiveness of boron in increasing hardenability is enhanced with increase in each of these elements.

\section{(b) Commercial Steels}

The curves obtained from the results of the end-quench tests of the commercial steels listed in table 8 are given in figure 30 , and the distances from the quenched-end of the Jominy bars corresponding to hardness values of Rockwell C 50 and C 42 (approximately 95 and 50 percent of martensite, respectively, table 10) are summarized in figure 31.

In all cases, the hardenability was materially improved by the addition of boron in the ingot mold, but no definite correlation was obtained between the degree of hardenability (on the basis of the distances from the quenched-end for 95 or 50 percent martensite), and the amount of boron retained in the steels or the composition of the ferroalloys used for the additions. As is shown in figure 31 , only a small difference in hardenability was obtained by varying the boron additions (retained boron ranging from about 0.0001 to $0.004 \%$ ) with Silcaz No. 3, Grainal No. 79, Ferroboron, Bortam, or Borosil. The average hardenability of the steels treated with these ferroalloys containing boron was slightly superior to the hardenability obtained by the smallest addition of either Grainal No. 1 or Silvaz No. 3 (about 0.0001 and $0.0007 \%$ of boron, respectively) and slightly inferior to the maximum obtained with higher additions of the two latter ferroalloys.
These differences are not considered significant. As already pointed out, however, boron tends to lower the coarsening temperature of austenite, and the presence of the grain-growth inhibiting elements contained in the complex ferroalloys may be of distinct advantage in preventing grain coarsening at heat-treating temperatures.

As all the steels had approximately the same low-nitrogen content (table 8), it is believed that this element affected equally the hardenability of each of the steels treated with boron.

The average hardenability of the boron-treated steels was of the same order as that of C4145 when comparisons were based upon the distance from the quenched end of the Jominy bars for Rockwell C 50 and somewhat inferior on the basis of a Rockwell value of C 42. However, a considerably higher value for hardness at $2 \frac{1}{2}$ in. from the quenched end was obtained in the SAE steel than in the special steels.

These results, therefore, show that the hardenability of the steels comprising a basic open hearth heat containing approximately 0.43 percent of carbon, 1.6 percent of manganese, 0.30 percent of silicon was markedly improved by the addition of boron in the ingot mold, but the magnitude of the effect was not critically dependent upon the amount of the addition or the composition of the intensifier used.

\section{(c) Effect of Austenitizing Temperature}

Grange [23] presented evidence indicating that the increase in hardenability conferred by boron was affected by the austenitizing temperature and prior heat treatment. The hardenability of a boron-treated steel did not increase regularly with increase in size of the austenite grains or with the increase in the austenitizing temperature, and it appeared that any treatment that precipitated a boron constituent substantially destroyed the effect of boron in subsequently reheated and quenched specimens. He described a heat treatment for precipitating a boron constituent and the preparation of the heat-treated specimen for microscopic examination. The heat treatment that he found best for hypoeutectoid steels consisted of austenitizing at a high temperature (about $2,000^{\circ} \mathrm{F}$ ) and then quenching in lead or salt at $1,200^{\circ} \mathrm{F}$, holding in the bath at this temperature for a time sufficient to precipitate the constituent and finally quenching in water or brine. 


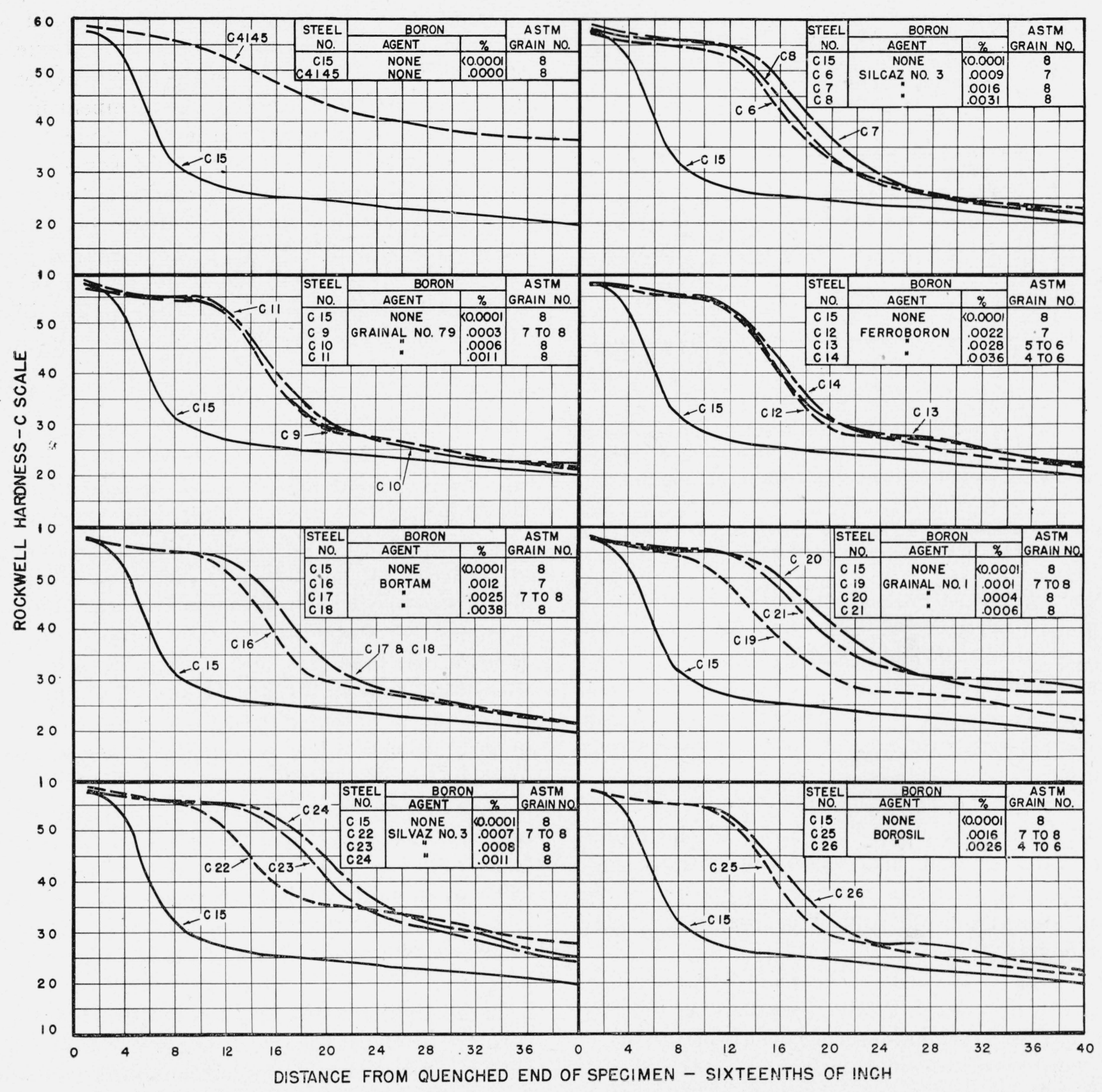

Figure 30.-Hardenability curves of commercial steels containing 0.45 percent of carbon.

The chemical composition of the steels is given in table 8. Specimens were normalized at $1,650^{\circ} \mathrm{F}$ and end-quenched from $1,550^{\circ} \mathrm{F}$; AST Mrain number at $1,550^{\circ} \mathrm{F}$.

No evidence of a boron constituent was observed in the metallographic examination of all the steels as normalized, in some end-quenched bars, austenitized at the usually recommended temperature, of steels with low or high hardenability, in some end-quenched bars of steels with low hardenability austenitized at $1,900^{\circ} \mathrm{F}$, or in specimens of the latter steels as hot-rolled. However, a chain-like constituent was observed in several endquenched bars of boron-treated steels of high hardenability austenitized at $1,900^{\circ} \mathrm{F}$. Except for one steel, this constituent was also clearly observed in specimens of all the boron-treated steels of high hardenability that were subjected to a special heat treatment, similar to that described by Grange. The exception was steel C19 that contained 0.0001 percent of boron by chemical analysis and had the expected increase in hardenability due to boron (fig. 31) but only a trace of the boron constituent was observed micro- 


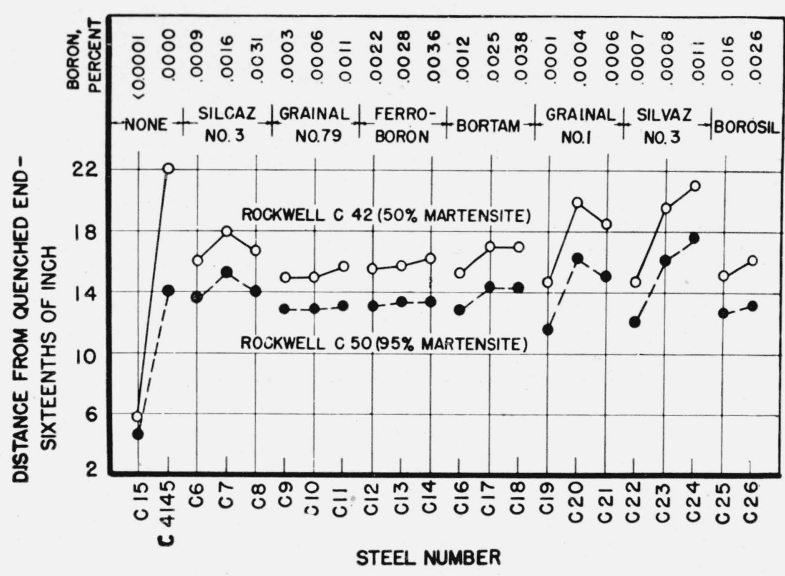

Figure 31.-Comparison of the hardenability of commercial sieels containing 0.45 percent of carbon and varying amounts of boron additions with different intensifiers.

The chemical composition of the steels is given in table 8 and intensifiers in table 9. Specimens were normalized at $1,650^{\circ} \mathrm{F}$ and end-quenched from $1,550^{\circ} \mathrm{F}$. The $\mathrm{ASTM}$ grain number at $1,550^{\circ} \mathrm{F}$ is given in figure 30 .

scopically in several specimens specially heattreated. Furthermore, in some of the borontreated steels of high hardenability, the boron constituent was obtained in small specimens quenched directly from $2,000^{\circ} \mathrm{F}$ in a sodium hydroxide-water solution at room or low temperatures.

Although the boron constituent was preferentially formed in grain boundaries of the parent austenite, it was also observed within these grains. It was never observed, however, in the decarburized zones of any of the specially treated specimens.

In specially treated specimens of boron-steels of relatively low hardenability, such as $48,72,73$, 233, 251, 299, the amount of boron constituent, if observed at all, was minute and was only revealed with difficulty, whereas in similarly treated specimens of boron-treated steels of relatively high hardenability the amounts observed were usually considerably greater and the constituent could be readily found. Although this correlation of the boron constituent in specially treated specimens and hardenability as determined in the end-quench test was observed, there were some irregularities. For example, the commercial steels C14 and C19 had approximately the same hardenability when quenched from the recommended temperature (fig. 31), but quite different amounts of the constituent were observed in the special heat-treated specimens.
As some of the irregularities observed in the hardenability curves obtained in the end-quench tests might have been due to the selected quenching temperature, or time at this temperature, it was decided to carry out the test on similar specimens quenched from $1,900^{\circ} \mathrm{F}$ of some of the experimental steels that showed relatively low hardenability when quenched from the usually recommended temperature range. Similar hightemperature tests were made on several of the commercial steels to determine if the hardenability of these steels was affected by a change in austenite grain size.

A few end-quench tests were made, in which the time the specimens were held at the austenitizing temperature was varied, in order to determine if the low hardenability obtained in some of the experimental nickel-chromium and chromiummolybdenum steels was due to incomplete solution of carbides at the time of quenching. Only a slight improvement in hardenability was obtained in steels 245 (table 6 ) and 233 (table 7 ) by increasing the time at $1,600^{\circ} \mathrm{F}$ from 30 to $60 \mathrm{~min}$ utes (total time in furnace 45 and 75 minutes).

The curves obtained from the results of the endquench tests of some of the experimental steels quenched from $1,900^{\circ} \mathrm{F}$ are given in figure 32 . A comparison of these curves with those previously obtained from the end-quench test (quenched from $1,575^{\circ}$ or $1,600^{\circ} \mathrm{F}$ ) show that in some cases the hardenability of boron-treated steels was increased, and in other cases it was not affected or was decreased by quenching from the higher temperature. Normally, a change would be expected in hardenability with variation in quenching temperature provided the size of the grains also varied with the temperature; the hardenability generally increases with the grain size of austenite. The improvement observed by quenching from the higher temperature in boron-treated steels 14, 72, and 260 may be explained on the basis of a difference in grain size at the two quenching temperatures used, as improvements of the same order of magnitude were obtained in each of the base steels (13, 70, and 258) from the same heats due to an increase in their austenite grain sizes. It is interesting to note that when quenched from $1,900^{\circ} \mathrm{F}$, the hardenability of steel 70 without boron was again superior to its companion steel 72 , which contained 0.0006 percent of boron. 


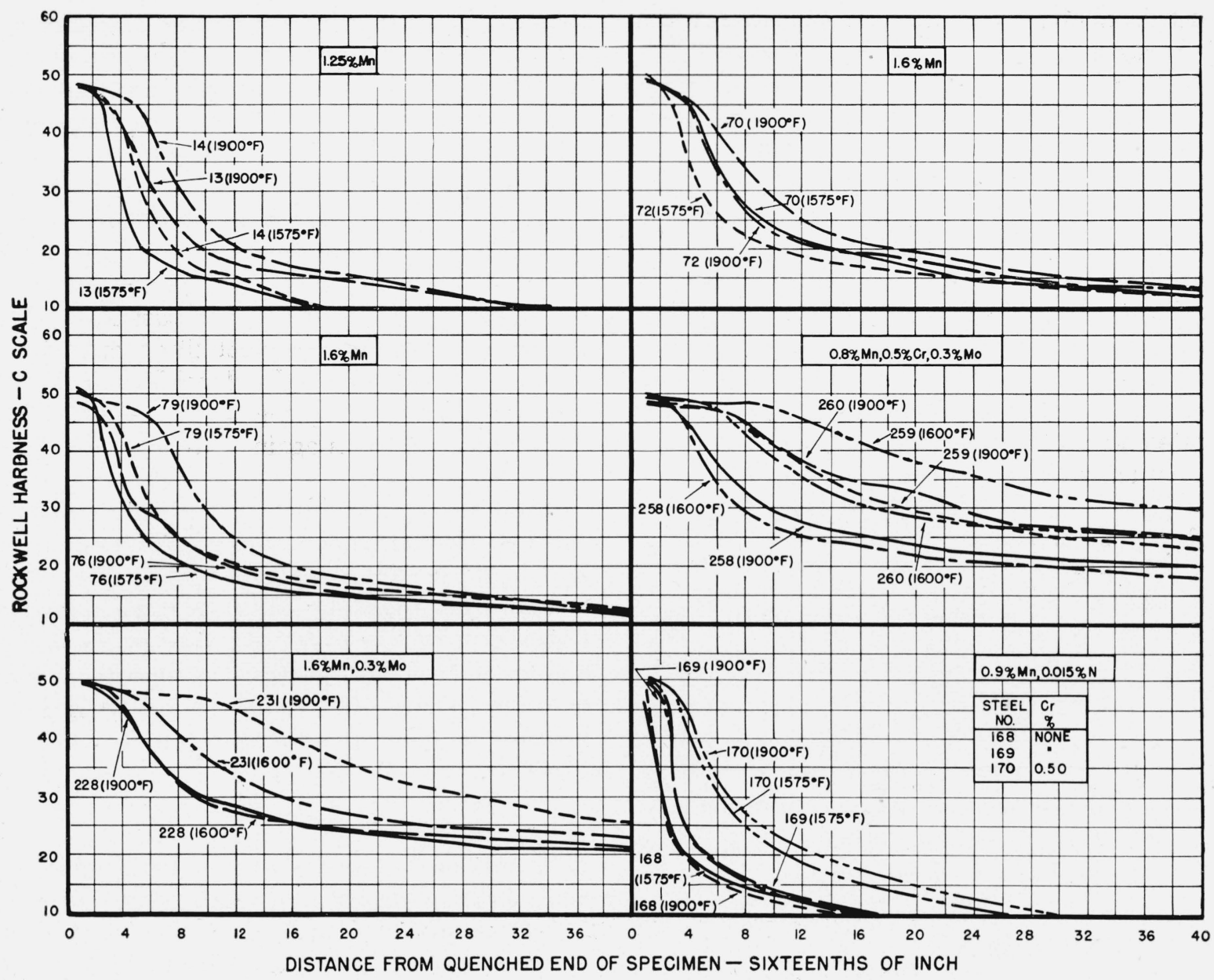

Figure 32.-Effect of quenching temperature on the hardenability of experimental steels containing 0.3 percent of carbon

\begin{tabular}{|c|c|c|c|c|c|c|c|c|c|c|c|}
\hline \multirow{2}{*}{$\begin{array}{l}\text { Steel } \\
\text { No. }\end{array}$} & \multicolumn{2}{|l|}{ Boron } & \multicolumn{3}{|c|}{ ASTM Grain No. at- } & \multirow{2}{*}{$\begin{array}{l}\text { Steel } \\
\text { No. }\end{array}$} & \multicolumn{2}{|c|}{ Boron } & \multicolumn{3}{|c|}{ ASTM Grain No. at- } \\
\hline & Agent & Amount & $1,575^{\circ} \mathrm{F}$ & $1,600^{\circ} \mathrm{F}$ & $1,900^{\circ} \mathrm{F}$ & & Agent & Amount & $1,575^{\circ} \mathrm{F}$ & $1,600^{\circ} \mathrm{F}$ & $1,900^{\circ} \mathrm{F}$ \\
\hline 13 & None_- & $\begin{array}{r}\text { Percent } \\
\text { None }\end{array}$ & 8 & & 1 to 8 & 259 & Grainal No. $79 \ldots$ & $\begin{array}{r}\text { Percent } \\
0.0005\end{array}$ & & 7 & 3 to 6 \\
\hline 14 & Ferroboron & 0.0020 & 7 & & 2 to 8 & 260 & _. do & .0005 & & 7 to 8 & 3 to 6 \\
\hline 70 & None & None & 3 to 7 & & 1 to 3 & 228 & None & None & & 7 to 8 & 2 to 6 \\
\hline 72 & Silcaz No. 3 & 0.0006 & 8 & & 2 to 7 & 231 & Ferroboron & 0.0013 & & 6 to 7 & 2 to 6 \\
\hline 76 & None & None & 8 & & 1 to 7 & 168 & None & None & 8 & ....... & 8 \\
\hline 79 & Grainal No. 79 & 0.0006 & 8 & $\cdots$ & -2 to 8 & 169 & Ferroboron & 0.0014 & 8 & 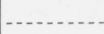 & 8 \\
\hline 258 & None & None & - & 8 & 3 to 6 & 170 & $\ldots$ do & .0016 & 8 & 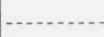 & 8 \\
\hline
\end{tabular}

Although some of the improvement in hardenability with increase in quenching temperature of steels 79 and 231 (treated with Grainal No. 79 and Ferroboron, respectively) may be due to a grain size effect, the test results suggest that some factor other than grain size is primarily responsible for the observed change. This is further substantiated by the results of tests made on steel 259 in which a marked decrease in hardenability was obtained by increasing the quenching temperature (size of the austenite grains also increased with temperature). A slight decrease in hardenability with increase in quenching temperature, such as was obtained in several steels from the same heat might be characteristic of the method (end-quench test) used in determining hardenability [24]. However, a change in quenching temperature from $1,575^{\circ}$ to $1,900^{\circ} \mathrm{F}$ did not materially affect 
the hardenability or austenite grain size of the high nitrogen steels with or without boron.

A wide difference is shown in the hardenability curves of figure 33 that were obtained from specimens quenched from $1,600^{\circ} \mathrm{F}$ (the usual recommended temperature range) of a steel (8585) used by Lorig and coworkers and a steel (268) of similar chemical composition (boron addition with Ferroboron) used in the present study. (All curves were obtained from end-quench tests carried out at the National Bureau of Standards and check determinations by spectrographic analysis for manganese, nickel, chromium, molybdenum, and boron also indicated that the steels were chemically alike). The hardenability of steel 268, however, was

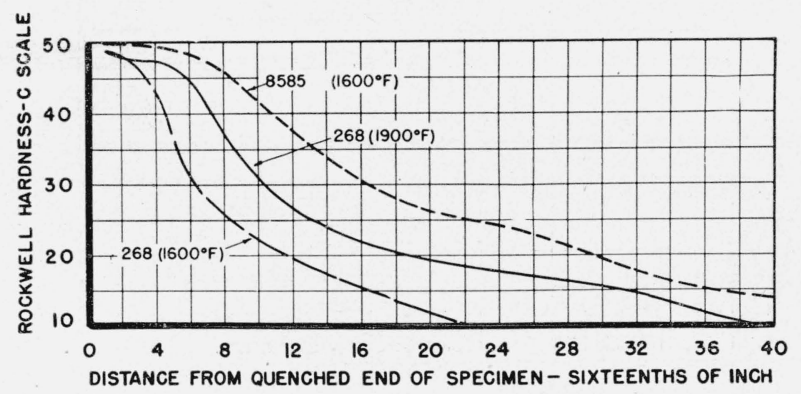

Figure 33.-Variation in hardenability from heat to heat of boron-treated experimental steels.

Each heat was deoxidized with 0.10 percent of aluminum before adding the boron in the furnace with Ferroboron.

\begin{tabular}{|c|c|c|c|c|c|c|c|c|}
\hline Steel No. & $\mathrm{C}$ & Mn & $\mathrm{Si}$ & $\mathrm{Ni}$ & $\mathrm{Cr}$ & B & $\begin{array}{l}\text { Quench } \\
\text { ing } \\
\text { tem- } \\
\text { pera- } \\
\text { ture }\end{array}$ & $\begin{array}{l}\text { ASTM } \\
\text { Grain } \\
\text { No. at } \\
\text { quench- } \\
\text { ing temp. }\end{array}$ \\
\hline $8585 \ldots$ & $\begin{array}{l}\text { Per- } \\
\text { cent } \\
0.30\end{array}$ & $\begin{array}{l}\text { Per- } \\
\text { cent } \\
0.86\end{array}$ & $\begin{array}{l}\text { Per- } \\
\text { cent } \\
0.43\end{array}$ & $\begin{array}{l}\text { Per- } \\
\text { cent } \\
0.56\end{array}$ & $\begin{array}{l}\text { Per- } \\
\text { cent } \\
0.51\end{array}$ & $\begin{array}{c}\text { Per- } \\
\text { cent } \\
0.0024\end{array}$ & $\begin{array}{l}{ }^{\circ} F \\
1,600\end{array}$ & \\
\hline $268 \ldots$ & .29 & .81 & .25 & .56 & .49 & .0028 & 1,600 & 8 \\
\hline $268 \ldots$ & .29 & .81 & .25 & .56 & .49 & .0028 & 1,900 & 1 to 8 \\
\hline
\end{tabular}

materially increased by a change in quenching temperature from $1,600^{\circ}$ to $1,900^{\circ} \mathrm{F}$. As both steels were prepared in the same laboratory using the same melting practice, similar base materials, ferroalloys, etc., it is somewhat surprising to find this marked difference in hardenability from heat to heat of boron-treated steels. It should be pointed out that the steels were not worked alike, but subsequent tests indicated that this variable was not responsible for the observed effects. If such variations are characteristic of commercial steels when quenched from the usual recommended temperatures, then the practical usefulness of treating steels of this particular base composition solely with Ferroboron is indeed questionable.

The effect of variation in quenching temperature on the hardenability of several of the commercial steels initially normalized at $1,650^{\circ} \mathrm{F}$ is shown in figure 34 . The minimum hardenability of each steel was obtained on quenching from $1,425^{\circ} \mathrm{F}$; a temperature below $A c_{3}$. As there was an incomplete solution of ferrite in the austenite at this temperature, a low hardenability would be expected. The increase in hardenability of the base steel with change in quenching temperature from $1,550^{\circ}$ to $1,900^{\circ} \mathrm{F}$ is again believed to be due to a grain size effect. Variations in quenching temperature from $1,550^{\circ}$ to $1,900^{\circ} \mathrm{F}$ had no material effect on the hardenability of steels $\mathrm{C} 14$ and C19, but the hardenability of steel $\mathrm{C} 12$ appeared to be partially destroyed by increasing the quenching temperature above $1,550^{\circ} \mathrm{F}$. That is, the hardenability of steel $\mathrm{C} 12$ attained a maximum when quenched from $1,550^{\circ} \mathrm{F}$ and then decreased with increase in quenching temperature to $1,650^{\circ}$ or $1,900^{\circ} \mathrm{F}$.

\section{(d) Discussion}

It has been shown that the hardenability of many of the experimental steels, which were prepared by induction melting without a slag, and all the steels comprising a basic-open hearth heat were markedly improved by a small addition of boron. However, no definite correlation was obtained between the hardenability effect due to boron and the amounts added or retained in the steels. In many of the experimental steels, the optimum hardenability was obtained with small additions of boron (0.001 percent or less retained), while in other steels the hardenability increased continuously with the amount retained. In still other steels, the addition of boron as a simple or complex ferroalloy or intensifier was either without effect, or impaired the hardenability. In general, relatively small amounts of boron were more effective than large; the complex intensifiers were more effective than the simple ones; the improvement in hardenability was not so critically dependent upon the amount of boron present when the additions were made with the complex as with the simple intensifiers; and the effectiveness of boron increased with increase in the amounts (within limits) of manganese, chromium, 


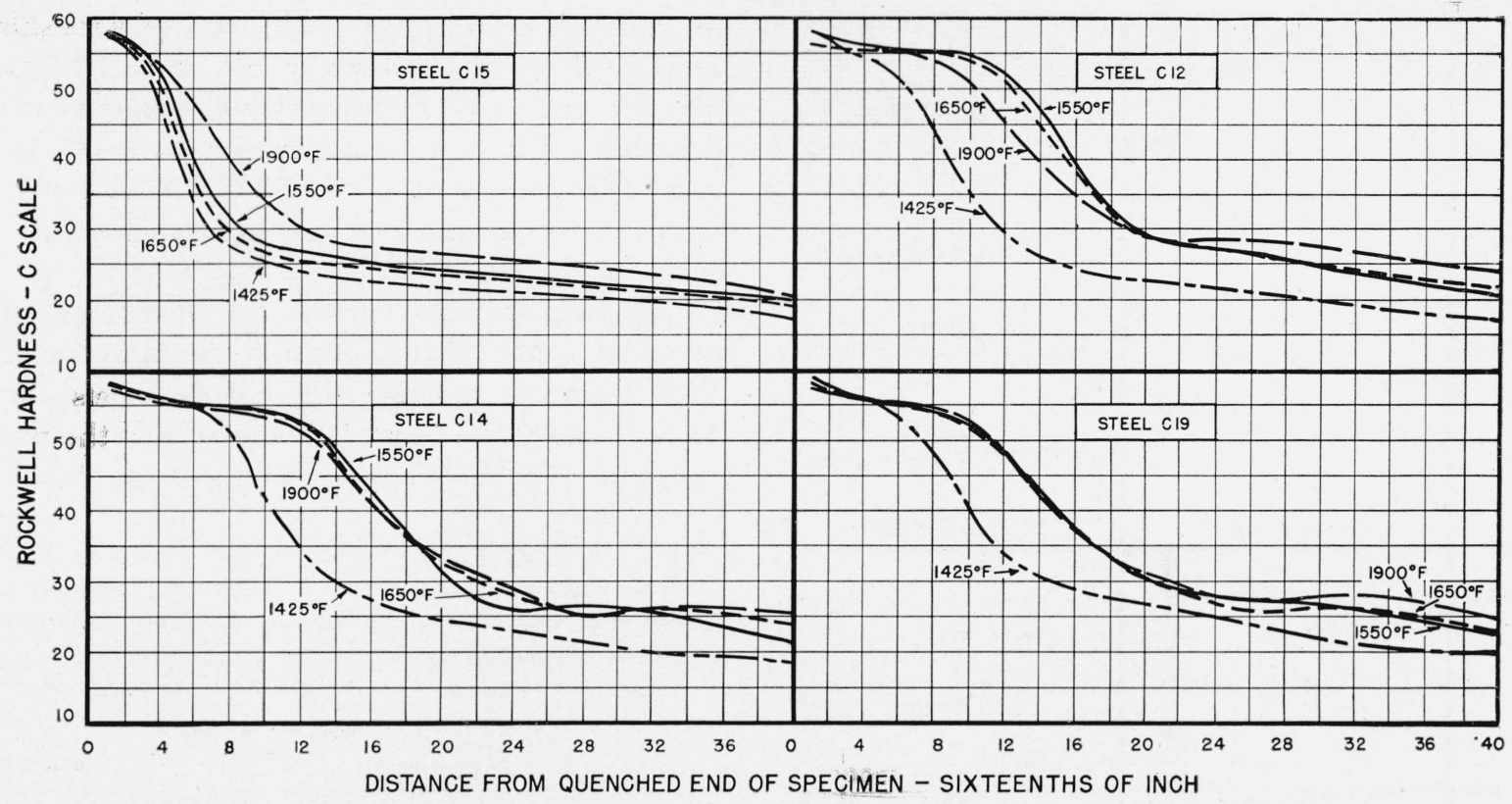

FIGURE 34.-Effect of quenching temperature on the hardenability of commercial steels containing 0.45 percent of carbon and 1.6 percent of manganese.

The chemical composition of the steels is given in table 8 . Specimens were normalized at $1,650^{\circ} \mathrm{F}$ before end-quenching from temperature as indicated.

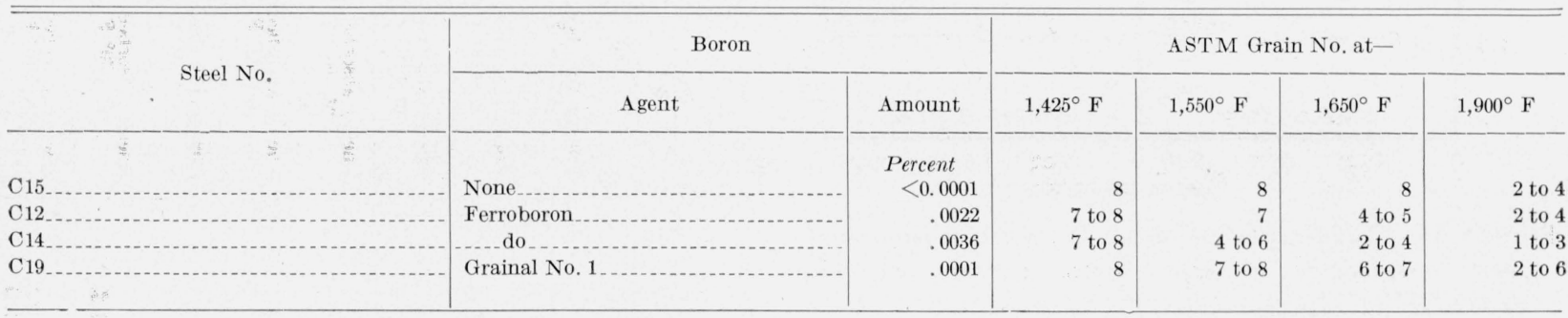

or molybdenum. The magnitude of the effect due to boron seems to depend upon the form in which the boron exists in austenite; not necessarily upon the total amount present. The response of boron-treated steels, therefore, varies with the deoxidation practice, and evidence was obtained that the hardenability of certain heats is sensitive to prior thermal treatments or structures. High soluble nitrogen (and possibly oxygen) is detrimental to the enhancement in hardenability due to boron, but it is possible to retain the effect in high nitrogen steels by "fixing" the nitrogen with strong nitride forming elements, such as titanium or zirconium.

\section{Notch Toughness}

A certain correlation exists between the appearance of the fractures and the energy absorbed in fracturing heat-treated Charpy V-notched steel specimens. A dull fibrous appearance with considerable deformation is characteristic of Charpy impact fractures of a tough material, whereas a bright, crystalline appearance with very small, if any deformation is typical of a brittle material. Partly fibrous and partly crystalline fractures are obtained in specimens tested in the transition range from tough to brittle materials. That is, the appearance of the fracture is a good criterion for detecting the absence or presence of notchbrittleness at the test temperature. Examinations were made of the fractured surfaces of all the Charpy ( $V$-notched) specimens used for test purposes. The above correlation was observed in nearly all cases. Obviously, in some cases, there was an appreciable difference in the values of duplicate specimens tested in the transition range. A noteworthy feature of the many tests carried out was the close agreement of the values obtained for duplicate specimens. 


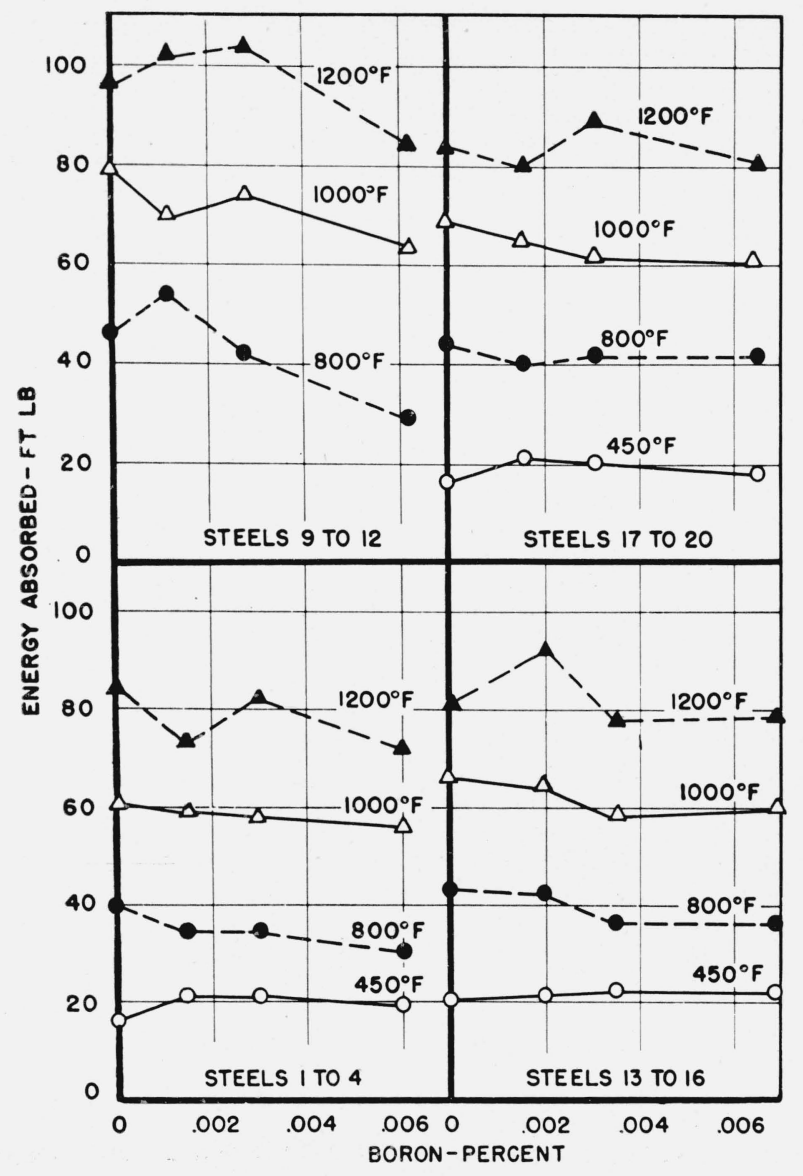

Figure 35.-Influence of boron on the notch toughness at room temperature of experimental carbon-manganese steels.

The chemical composition of the steels is given in table 1. The Charpy specimens were quenched from $1,575^{\circ} \mathrm{F}$ in water and tempered as indicated.

\section{(a) Experimental Steels}

1. Carbon-manganese.-The results of the Charpy tests made on the carbon-manganese steels listed in table 1 are summarized in figures 35 and 36 and table 11 .

The general trend was for the notch toughness at room temperature $\left(+70^{\circ} \mathrm{F}\right)$ of the steels fully hardened and then tempered alike (fig. 35) to be increased slightly by the boron when heat-treated for high hardness (tempered $450^{\circ} \mathrm{F}$ ) and to be decreased slightly by boron at low hardnesses (tempered at $1,000^{\circ}$ or $1,200^{\circ} \mathrm{F}$ ). The differences obtained were not large, and the trend is not considered significant. At subzero temperatures, however, the notch toughness was adversely affected by boron in some of the steels tempered at $1,000^{\circ}$ or $1,200^{\circ} \mathrm{F}$. As is illustrated in figure
36 , differences in degrees of toughness were shown in the 0.2 percent carbon steels (9 to 12 ) tested at $-40^{\circ}$ and $-95^{\circ} \mathrm{F}$ and in the 0.3 percent carbon, 0.8 and 1.2 percent manganese steels (17 to 20 and 13 to 16 ) tested at $-95^{\circ} \mathrm{F}$. This low-temperature brittleness was most pronounced in the high boron $(0.006 \%)$ steels. The slope of the energy-temperature curves for specimens tempered at $1,000^{\circ} \mathrm{F}$ (fig. 36) and the appearance of their fractures indicate that all the steels except 13 (and possibly 17 and 18 ) were within the brittle range at $-95^{\circ} \mathrm{F}$. The beginning of the transition

TABLE 11.-Effect of variation in rate of cooling from the tempering temperature on notch toughness (Charpy impact) at room and low temperatures of some experimental carbon-manganese steels

\begin{tabular}{|c|c|c|c|c|c|c|c|c|c|}
\hline \multirow{3}{*}{$\begin{array}{l}\text { Steel } \\
\text { No. }\end{array}$} & \multirow{3}{*}{ Boron } & \multicolumn{2}{|c|}{$\begin{array}{l}\text { Tempered at } \\
800^{\circ} \mathrm{F} \text {, cooled } \\
\text { in- }\end{array}$} & \multicolumn{4}{|c|}{$\begin{array}{l}\text { Tempered at } 1,000^{\circ} \mathrm{F}, \\
\text { cooled in- }\end{array}$} & \multicolumn{2}{|c|}{$\begin{array}{l}\text { Tempered at } \\
1,200^{\circ} \mathrm{F}, \\
\text { cooled in- }\end{array}$} \\
\hline & & $\begin{array}{l}\text { Still } \\
\text { air }\end{array}$ & Water & & air & & ter & $\begin{array}{c}\text { Still } \\
\text { air }\end{array}$ & Water \\
\hline & & 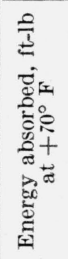 & 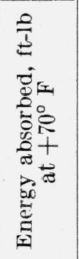 & 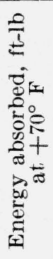 & 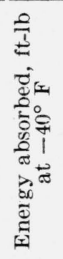 & 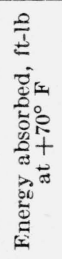 & 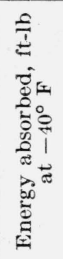 & 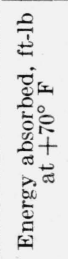 & 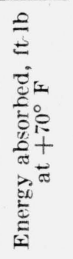 \\
\hline & $\begin{array}{l}\text { Per- } \\
\text { cent } \\
\text { None }\end{array}$ & 39 & 39 & 61 & 54 & & & 84 & 77 \\
\hline & 0.0015 & 34 & 35 & 59 & 54 & & & 73 & 77 \\
\hline & .0030 & 34 & 36 & 58 & 42 & & & 82 & 81 \\
\hline t. & .0060 & 30 & 29 & 56 & 43 & & & 72 & 73 \\
\hline $2 \ldots$ & .0062 & & - & 64 & 22 & 59 & 25 & & \\
\hline
\end{tabular}

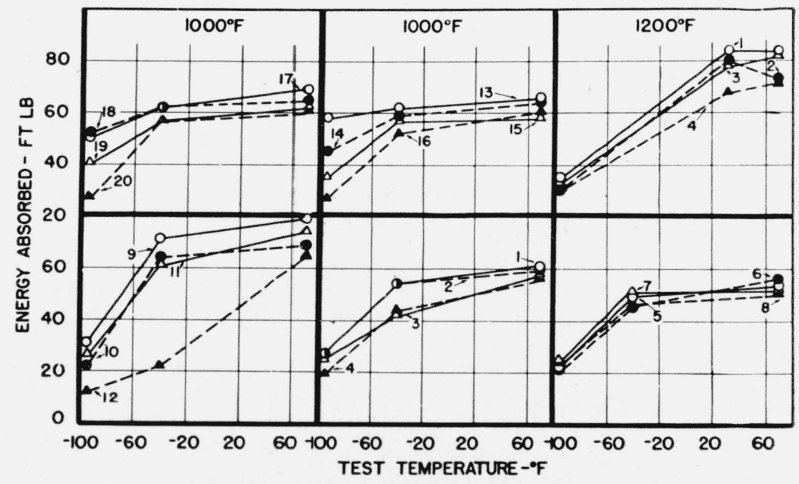

FIGURE 36.-Effect of test temperature on the notch toughness of experimental carbon-manganese steels

The chemical composition of the steels is given in table 1. The Charpy specimens were quenched from $1,475^{\circ} \mathrm{F}$ (steels 5 to 8 ) or $1,575^{\circ} \mathrm{F}$ (steels 1 to 4 and 9 to 20 ) in water and tempered at $1,000^{\circ}$ or $1,200^{\circ} \mathrm{F}$. 
range (from tough to brittle material) of steels 17 and 18 appeared to be about $-95^{\circ} \mathrm{F}$ and that of steels 3 and 4 at $-40^{\circ} \mathrm{F}$. Steel 12 was well within the brittle range at $-40^{\circ} \mathrm{F}$. The deleterious effect of 0.006 percent of boron in steel 12 on its notch toughness at low temperature suggested the possibility that this steel might be susceptible to temper brittleness. Accordingly, specimens were quenched in water from the tempering temperature $\left(1,000^{\circ} \mathrm{F}\right)$ and then tested at room temperature and $-40^{\circ} \mathrm{F}$ for comparison with the results obtained on the specimens cooled in air. Additional tests were also made to determine the effect of the rate of cooling from the tempering temperature on the notch toughness at room temperature of the 0.3 percent carbon, 1.6 percent manganese steels. The results, given in table 11, show that the notch toughness of these steels was not affected by variations in the rates used for cooling the specimens from the tempering temperatures.

The notch toughness at room temperature of the 1.6 percent manganese steels fully quenched and then tempered alike decreased somewhat with increase in carbon from 0.2 to 0.3 or 0.45 percent, whereas the toughness at $-95^{\circ} \mathrm{F}$ was not so noticeably affected by this change. The notch toughness at room or subzero temperatures was not improved in the 0.3 percent carbon steels by increasing the manganese from 0.8 to 1.2 or 1.6 percent.

2. Deoxidation practice.-The results of the Charpy tests made on the carbon-manganese steels that are listed in table 2 are summarized in figures 37,38 , and 39 .

The spread obtained in values was not large for all the steels comprising a heat, either deoxidized or not treated with aluminum, when the specimens were fully hardened and tempered alike and then tested at room temperature (fig. 37). Again, there was a slight trend for the notch toughness at $+70^{\circ} \mathrm{F}$ to be higher in some of the boron-treated than in the base steels when tempered for high hardness and to be lower when tempered for low hardness. The differences in value for the steels treated with the various intensifiers were not appreciably greater than those obtained in the base steels prepared with or without aluminum.

The magnitudes and trends of the effects on notch toughness of the steels tempered at $1,000^{\circ}$ $\mathrm{F}$, resulting from changes in test temperature, boron content with various intensifiers, and deoxidation are shown in figures 38 and 39 . Variation in test temperature from $+70^{\circ}$ to $-95^{\circ} \mathrm{F}$ had no significant effect on the notch toughness of two of the base steels (64 and 76) deoxidized with aluminum but the notch toughness of another steel (1) similarly prepared and all base steels (33, 37, 70, and 110) not deoxidized with aluminum were adversely affected by this change. Variations in test temperatures from $+70^{\circ}$ to $-95^{\circ} \mathrm{F}$ also had no appreciable effect on the notch toughness of some of the steels containing boron, such as 66,73 , and 74 , whereas in other boron-treated steels the toughness was adversely affected, especially in those with high boron. In general, the resistance to notch brittleness at $+70^{\circ},-40^{\circ}$ and $-90^{\circ} \mathrm{F}$ of the fine-grained steels with relatively small amounts of boron compare favorably with that of the fine-grained steels (aluminum-killed) without boron (fig. 39).

A noteworthy feature is the high notch toughness at $-95^{\circ} \mathrm{F}$ of all the steels comprising a heat deoxidized with aluminum and treated with Grainal No. 79 (steels 76 to 81 , fig. 39 ) and several steels from each beat that was treated with Silcaz No. 3.

Thus the notch toughness of these 0.3 percent carbon, 1.6 percent manganese steels varied with the hardness, test temperature, boron content and state of deoxidation.

3. Nitrogen.-The results of the Charpy tests made on the nitrogen steels listed in table 3 are summarized in figures 40 to 43 .

The notch toughness at room temperature of the steels increased with increase in tempering temperature. There was an appreciable scatter in the values obtained, especially after tempering at the higher temperatures and testing at low temperatures.

Variations in nitrogen from 0.004 to about 0.030 percent had no marked influence on the notch toughness at room temperature of the steels heattreated for various hardness values or on the notch toughness at low temperatures $\left(-40^{\circ}\right.$ and $\left.-95^{\circ} \mathrm{F}\right)$ of the steels tempered at $1,000^{\circ} \mathrm{F}$ (fig. 40). Some trends, believed to be insignificant, were observed, such as a decrease in toughness at room temperature with increase in nitrogen from low to medium values for the steels with 0 and 0.0015 percent of boron without titanium when tempered at $1,000^{\circ}$ or $1,200^{\circ} \mathrm{F}$. It should be pointed out, however, 


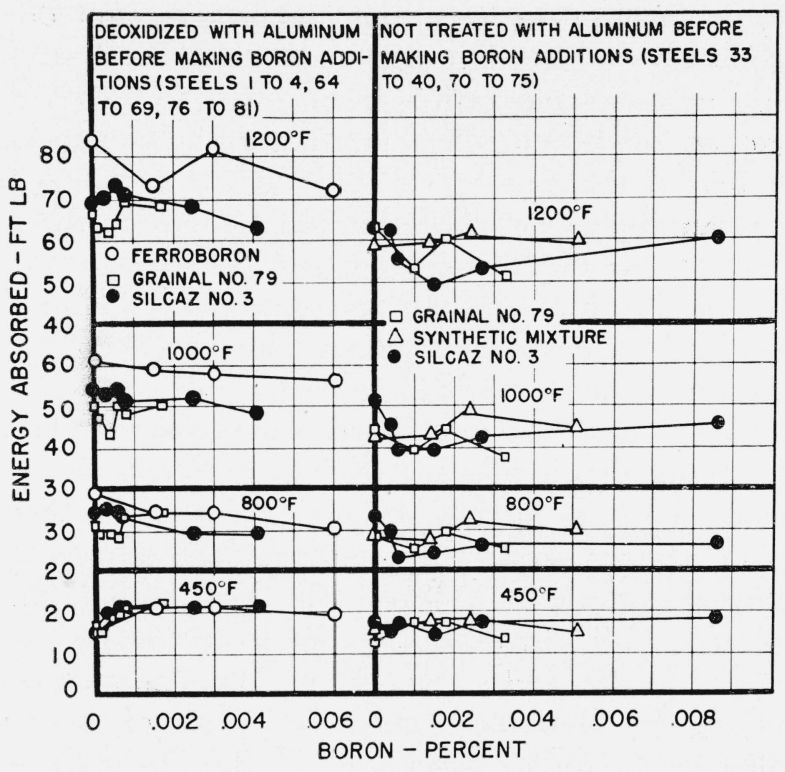

FiguRE 37.-Influence of boron additions made with various intensifiers on the notch toughness at room temperature of experimental steels containing 0.3 percent of carbon and 1.6 percent of manganese.

The chemical composition of the steels is given in tables 1 and 2 and intensifiers in table 9 . The Charpy specimens were quenched from $1,575^{\circ} \mathrm{F}$ in water and tempered as indicated.

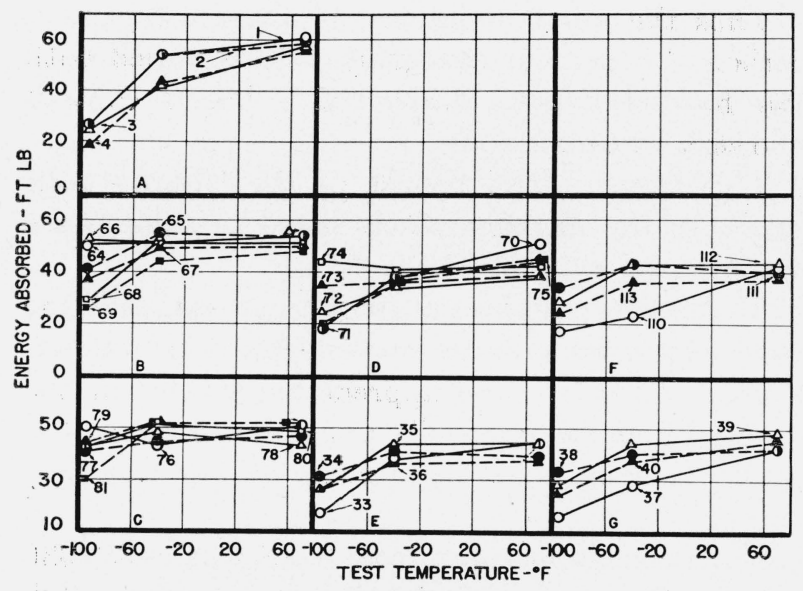

Figure 38.-Effect of test temperature on the notch toughness of experimental steels containing 0.3 percent of carbon and 1.6 percent of manganese treated with various intensifiers.

The chemical composition of the steels is given in tables 1 and 2. The Charpy specimens were quenched from $1,575^{\circ} \mathrm{F}$ in water and tempered at $1,000^{\circ} \mathrm{F}$. A, Steels 1 to 4 , deoxidized with 0.10 percent of $\mathrm{Al}$, treated with Ferroboron; B, steels 64 to 69 , deoxidized with 0.10 percent of Al, treated with Silcaz No. 3; C, steels 76 to 81 , deoxidized with 0.05 percent of Al, treated with Grainal No. 79; D, steels 70 to 75 , not deoxidized with Al, treated with Silcaz No. 3; E, steels 33 to 36, not deoxidized with Al, treated with Grainal No. 79; F, steels 110 to 113 , not deoxidized with $\mathrm{Al}$, treated with synthetic mixture without boron; $\mathrm{G}$, steels 37 to 40 , not deoxidized with Al, treated with synthetic mixture containing boron.

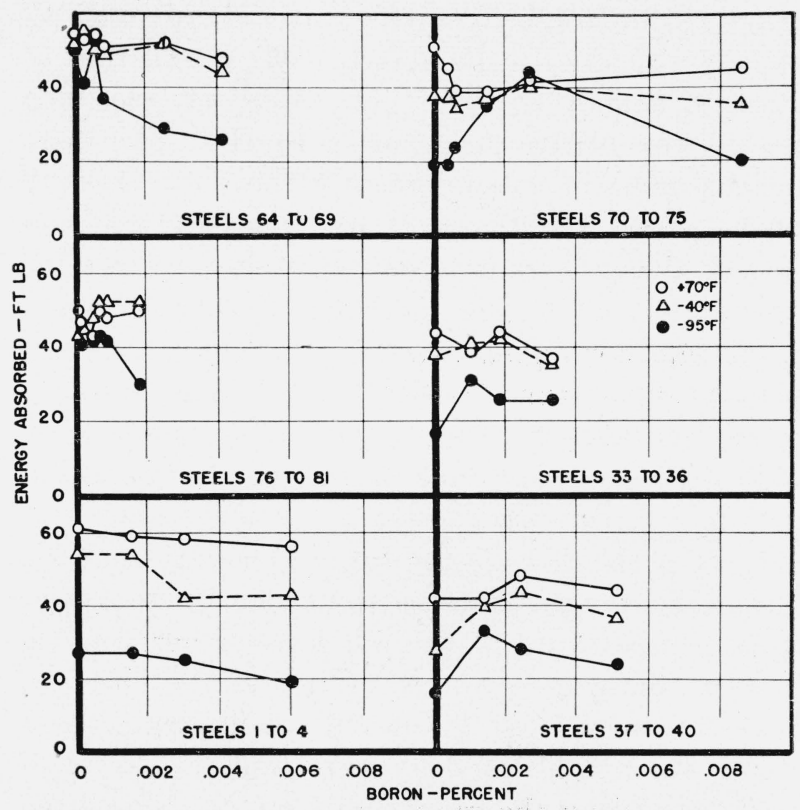

FiguRE 39.--Influence of boron additions made with various intensifiers on the notch toughness at $+70^{\circ},-40^{\circ}$ and $-95^{\circ} F$ of experimental steels containing 0.3 percent of carbon and 1.6 percent of manganese.

The chemical composition of the steels is given in tables 1 and 2 . The Charpy specimens were quenched from $1,575^{\circ} \mathrm{F}$ in water and tempered at $1,000^{\circ}$ F. Steels 1 to 4 , deoxidized with 0.10 percent of $\mathrm{Al}$, treated with Ferroboron; steels 76 to 81 , deoxidized with 0.05 percent of $\mathrm{Al}$, treated with Grainal No. 79 ; steels 64 to 69 , deoxidized with 0.10 percent of $\mathrm{Al}$, treated with Silcaz No. 3 ; steels 70 to 75 , not deoxidized with Al, treated with Silcaz No. 3 ; steels 33 to 36 , not deoxidized with Al, treated with Grainal No. 79; steels 37 to 40 , not deoxidized with $\mathrm{Al}$, treated with synthetic mixture containing boron.

that with low nitrogen, there was a significant trend for the notch toughness at room and low temperatures of the steels with boron $(0.0015$ and $0.003 \%$ ) and about 0.10 percent of titanium to be lower than that of the base steels or the steels containing low concentrations of titanium (treated with Grainal). The effect of titanium on the notch toughness at $+70^{\circ},-40^{\circ}$, and $-95^{\circ} \mathrm{F}$ of the steels with high nitrogen and 0.0015 percent of boron (additions with Ferroboron) is shown in figure 41). The addition of 0 to 0.15 percent of titanium had no material effect on the notch toughness at $+70^{\circ}$ or $-40^{\circ} \mathrm{F}$ of these boronnitrogen steels, but the notch toughness was usually decreased with the addition of 0.36 percent. (At the higher hardness, tempered at $450^{\circ} \mathrm{F}$, the toughness at $+70^{\circ} \mathrm{F}$ of the latter steel was as high as that of the steels with low titanium.) 'The trend was for the notch toughness at $-95^{\circ} \mathrm{F}$ (steels tempered at $1,000^{\circ} \mathrm{F}$ ) to decrease slightly with increase in titanium. 


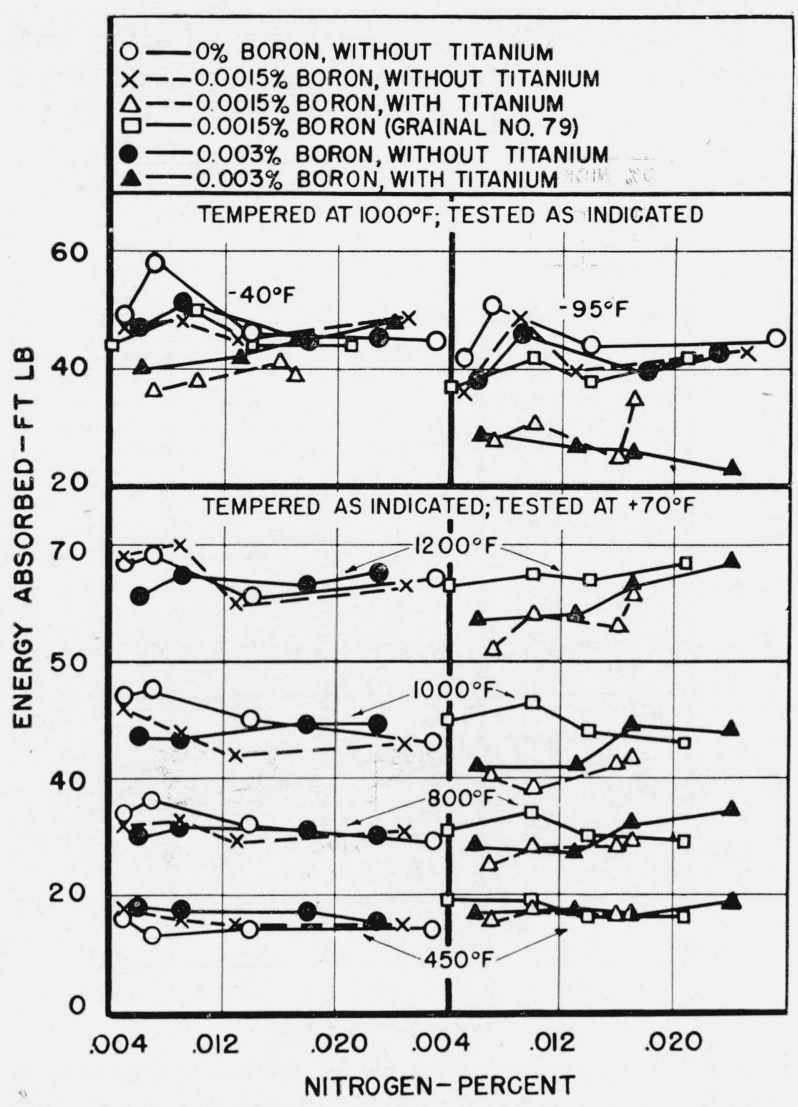

FIGURE 40.--Influence of nitrogen on the notch toughness at $+70^{\circ},-40^{\circ}$ and $-95^{\circ} \mathrm{F}$ of experimental steels containing 0.3 percent of carbon and 1.6 percent of manganese.

The chemical composition of the steels (138 to 155 and 180 to 185) is given in table 3 . The Charpy specimens were quenched from $1,575^{\circ} \mathrm{F}$ in water and tempered as indicated.

The effect of chromium on the notch toughness at $+70^{\circ},-40^{\circ}$, and $-95^{\circ} \mathrm{F}$ of the high-nitrogen steels is shown in figure 42. At relatively high hardness ( $R e 46$ to 49 , tempered at $450^{\circ} \mathrm{F}$ ) the addition of chromium up to 0.75 percent had no marked effect on notch toughness at $+70^{\circ} \mathrm{F}$, whereas the values obtained with the chromium steels tempered at $800^{\circ}, 1,000^{\circ}$, or $1,200^{\circ} \mathrm{F}$ were lower than similarly treated steels without chromium. It should be pointed out that chromium steels resist softening by tempering and somewhat higher values for hardness after tempering at the higher temperatures were obtained on these steels than on the steels without chromium; notch toughness usually decreases with increase in hardness of heat-treated steels. The trend also was for the notch toughness at $-40^{\circ}$ and $-90^{\circ} \mathrm{F}$ to decrease with increase in chromium. The addition of

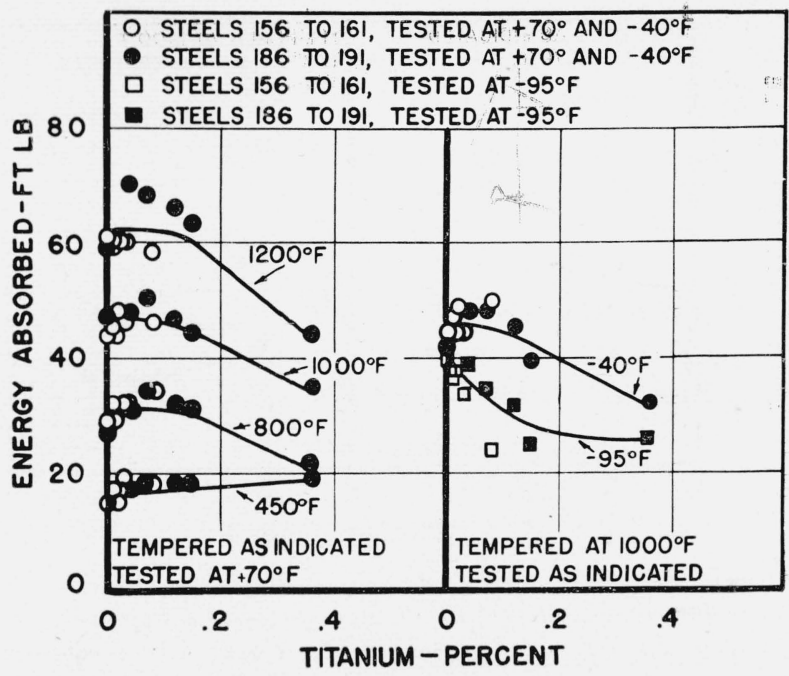

FIGURE 41.-Influence of titanium on the notch toughness at $+70^{\circ},-40^{\circ}$ and $-95^{\circ} \mathrm{F}$ of experimentai high-nitrogen steels containing 0.3 percent of carbon, 1.6 percent of manganese, and 0.0015 percent of boron.

The chemical composition of the steels is given in table 3. The Charpy specimens were quenched from $1,575^{\circ} \mathrm{F}$ in water and tempered as indicated.

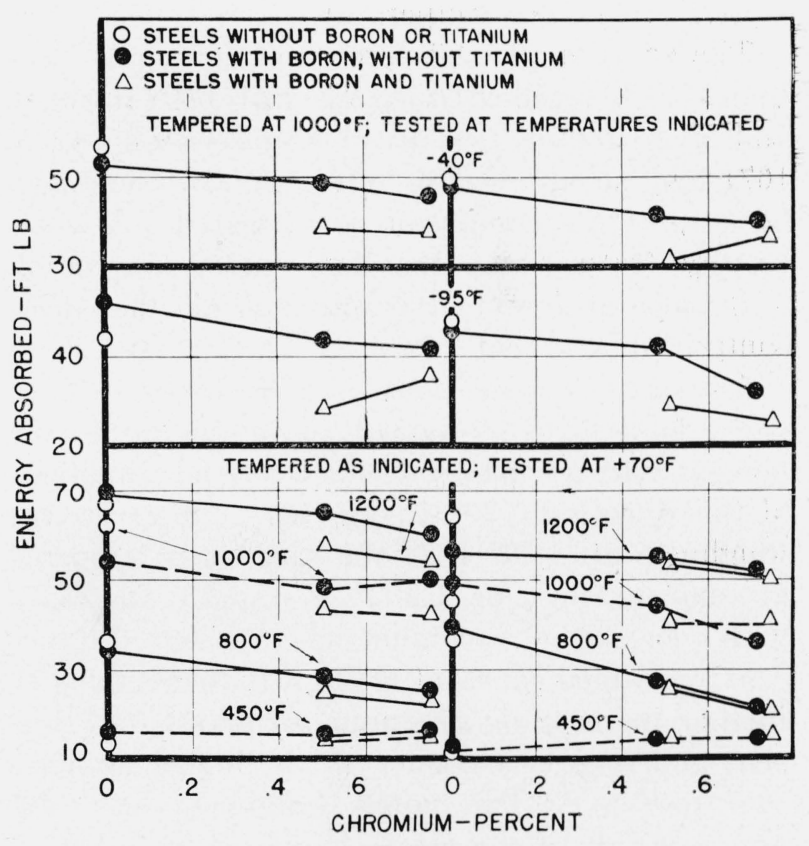

FIGURE 42.-Influence of chromium on the notch toughness at $+70^{\circ},-40^{\circ}$, and $-95^{\circ} F$ of experimental high nitrogen steels containing 0.3 percent of carbon and 0.8 percent of manganese.

The chemical composition of the steels (168 to 173 and 198 to 203) is given in table 3. The Charpy specimens were quenched from $1,575^{\circ} \mathrm{F}$ in water and tempered as indicated. 


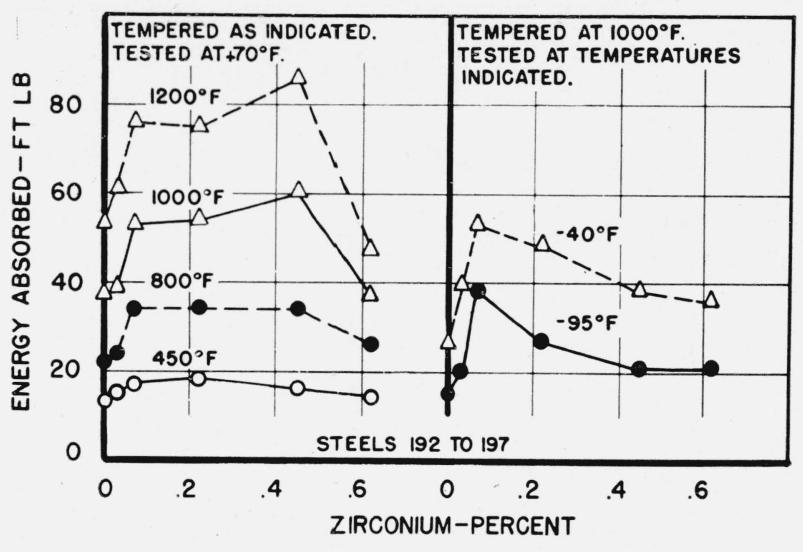

FIGURE 43.-Influence of zirconium on the notch toughness at $+70^{\circ},-40^{\circ}$, and $-95^{\circ} \mathrm{F}$ of experimental high-nitrogen steels containing 0.3 percent of carbon, 1.6 percent of manganese and 0.0015 percent of boron.

The chemical composition of the steels is given in table 3. The Charpy specimens were quenched from $1,575^{\circ} \mathrm{F}$ in water and tempered as indicated.

about 0.10 or 0.25 percent of titanium to different heats adversely affected the notch toughness at $+70^{\circ},-40^{\circ}$, and $-95^{\circ} \mathrm{F}$ of the high-nitrogen steels with chromium and boron when tempered at relatively high temperatures.

The addition of 0.20 percent of zirconium (less than $0.01 \%$ retained) to steels with high nitrogen and about 0.0015 percent of boron (steels 162 to 167) had no appreciable effect on the toughness for any of the conditions investigated. A noteworthy feature was the high values for notch toughness at low temperature of all the steels comprising this heat.

At relatively high hardness ( $R e$ 45 to 48 tempered at $450^{\circ} \mathrm{F}$ ), retained zirconium up to 0.6 percent had no material effect on the toughness of the steels at $+70^{\circ} \mathrm{F}$ (fig. 43). However, the toughness at $+70^{\circ} \mathrm{F}$ of the specimens tempered at $800^{\circ}, 1,000^{\circ}$, or $1,200^{\circ} \mathrm{F}$ rapidly increased with increase in zirconium up to about 0.1 percent; remained constant or slightly increased with further increase in zirconium to about 0.45 percent and then decreased with the higher addition (0.6 percent). The notch toughness at $-40^{\circ}$ and $-95^{\circ} \mathrm{F}$ of the steels tempered at $1,000^{\circ} \mathrm{F}$ (Rc 25 to 30 ) also rapidly increased with increase in zirconium to about 0.1 percent and thereafter decreased with the zirconium. The values for notch toughness at $+70^{\circ} \mathrm{F}$ of the steels with 0.0 and 0.6 percent of zirconium were of the same order of magnitude when treated alike.
4. Nickel.-The results of the Charpy tests made on the nickel steels listed in table 4 are summarized in figure 44 .

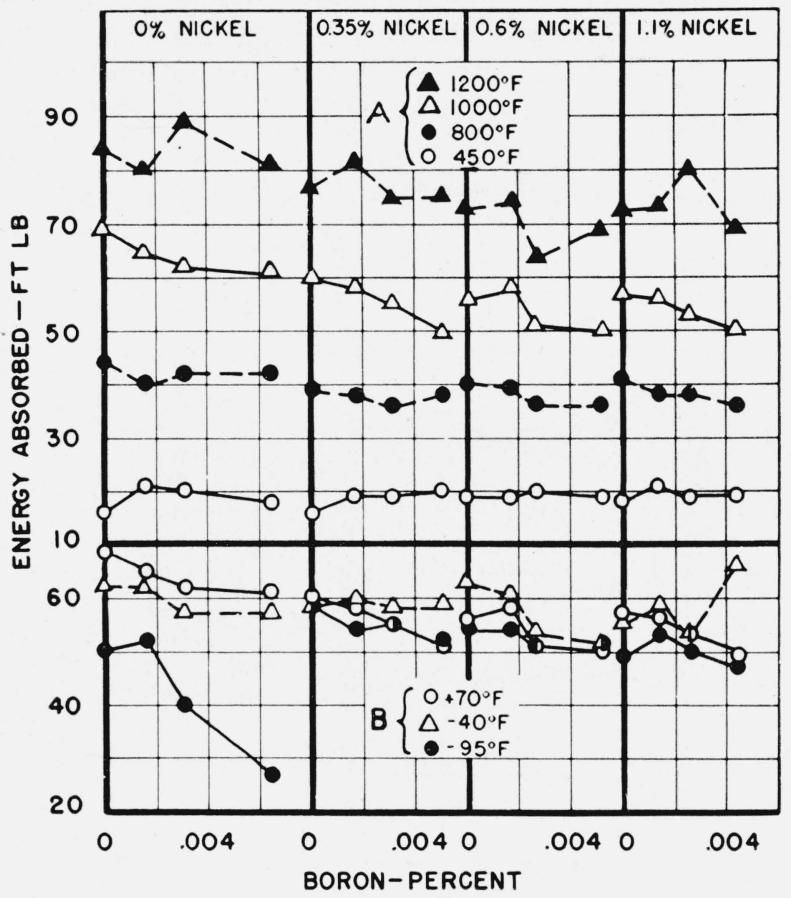

FIGURE 44.-Influence of boron on the notch toughness at $+70^{\circ},-40^{\circ}$, and $-95^{\circ} \mathrm{F}$ of experimental nickel steels containing 0.3 percent of carbon and 0.8 percent of manganese.

The chemical composition of the steels is given in table 4. The Charpy specimens were quenched from $1,575^{\circ} \mathrm{F}$ in water and tempered at $450^{\circ}, 800^{\circ}$, $1,000^{\circ}$ or $1,200^{\circ} \mathrm{F}$. A, tempered at temperature as indicated, tested at $+70^{\circ}$ $\mathrm{F}, \mathrm{B}$, tempered at $1,000^{\circ} \mathrm{F}$, tested at temperature as indicated.

The notch toughness at room temperature of the fully hardened 0.8 percent manganese steels with nickel ranging from nil to 1.1 percent and boron from 0 to 0.0065 percent increased continuously with increase in the tempering temperatures used (decrease in hardness). This toughness was not materially affected by variations in boron or nickel contents. For steels tempered at $1,000^{\circ} \mathrm{F}$, the trend was for the notch toughness at $+70^{\circ},-40^{\circ}$ and $-95^{\circ} \mathrm{F}$ to decrease with increase in boron and a change in test temperature from $-40^{\circ}$ to $-95^{\circ} \mathrm{F}$ adversely affected the notch toughness of the steels without nickel. The toughness of nickel steels, with or without boron, was not appreciably affected by variations in test temperature.

5. Chromium.-The results of the Charpy tests made on the chromium steels listed in table 5 are summarized in figures 45 and 46 . 


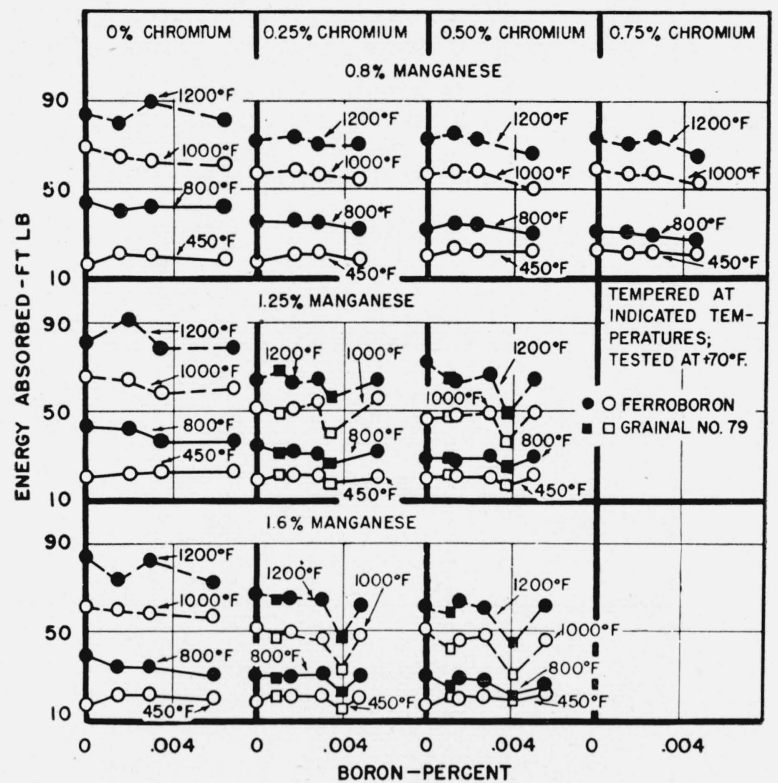

Figure 45.-Influence of boron on the notch toughness at room temperature of experimental chromium steels containing 0.3 percent of carbon, and $0.8,1.25$ or 1.6 percent of manganese as fuily hardened and tempered at different temperatures.

The chemical composition of the steels is given in table 5. The Charpy specimens were quenched from $1,575^{\circ} \mathrm{F}$ in water and tempered as indicated.

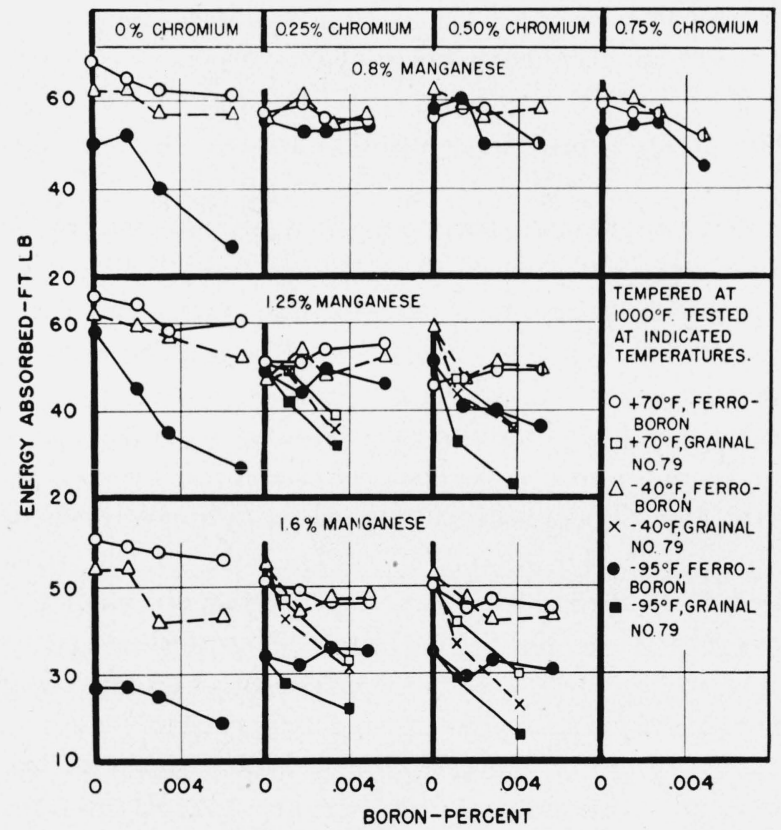

Figure 46.-Influence of boron on the notch toughness at $+70^{\circ},-40^{\circ}$, and $-95^{\circ} \mathrm{F}$ of experimental chromium steels containing 0.3 percent of carbon, and $0.8,1.25$ or 1.6 percent of manganese.

The chemical composition of the steels is given in table 5. The Charpy specimens_were quenched from $1,575^{\circ} \mathrm{F}$ in water and tempered at $1,000^{\circ} \mathrm{F}$.
The notch toughness at $+70^{\circ} \mathrm{F}$ increased with increase in tempering temperature of the fully hardened steels. For any selected tempering temperature used, the values for notch toughness of the steels comprising each heat fall within a rather narrow range, except for the steels treated with Grainal No. 79 for high boron $(0.006 \%$ added, 0.003 to $0.004 \%$ retained). The notch toughness at $+70^{\circ} \mathrm{F}$ of the latter steels (119, 125,131 , and 137) was inferior to that of the remaining steels comprising each group or heat.

The relation of energy absorbed to boron content of the steels tempered at various temperatures is given in figure 45. At relatively high hardness (tempered at $450^{\circ} \mathrm{F}$ ), the trend again was for the steels treated with either Grainal No. 79 or Ferroboron for relatively low-boron content to have slightly higher values for notch toughness at $+70^{\circ} \mathrm{F}$ than the steels without boron. At relatively low hardness (high tempering temperatures) the boron additions usually were not beneficial; in the case of the high-boron steels treated with Grainal the notch toughness was definitely lower than that of the base steel.

The general trend was for the notch toughness at $+70^{\circ},-40^{\circ}$, and $-95^{\circ} \mathrm{F}$ of the steels tempered at $1,000^{\circ} \mathrm{F}$ to decrease with increase in boron, especially when the additions were made with Grainal No. 79 (fig. 46). For the 0.8 percent of manganese steels with chromium, change in test temperature from $+70^{\circ}$ to $-95^{\circ} \mathrm{F}$ had no marked effect on the notch toughness. At test temperatures of $+70^{\circ}$ and $-40^{\circ} \mathrm{F}$ the notch toughness of the 0.8 percent manganese steels was not improved by chromium, but the addition of 0.25 to 0.75 percent of chromium was effective in preventing cold brittleness at $-95^{\circ} \mathrm{F}$. That is the transition range from tough to brittle material of these 0.8-percent manganese-chromium-boron steels was below $-95^{\circ} \mathrm{F}$. The addition of chromium to the steels with 1.25 or 1.6 percent of manganese with or without boron did not result in an improvement in notch toughness at $+70^{\circ}$ or $-40^{\circ} \mathrm{F}$; at $-95^{\circ} \mathrm{F}$ the notch toughness of the boron steels was, in general, increased slightly by the presence of about 0.25 percent of chromium. The general trend also was for the notch toughness at all test temperatures of the chromium steels to decrease slightly with increase in manganese content. 
6. Nickel-chromium.-The results of the Charpy tests made on the nickel-chromium steels listed in table 6 are summarized in figures 47 and 48 .

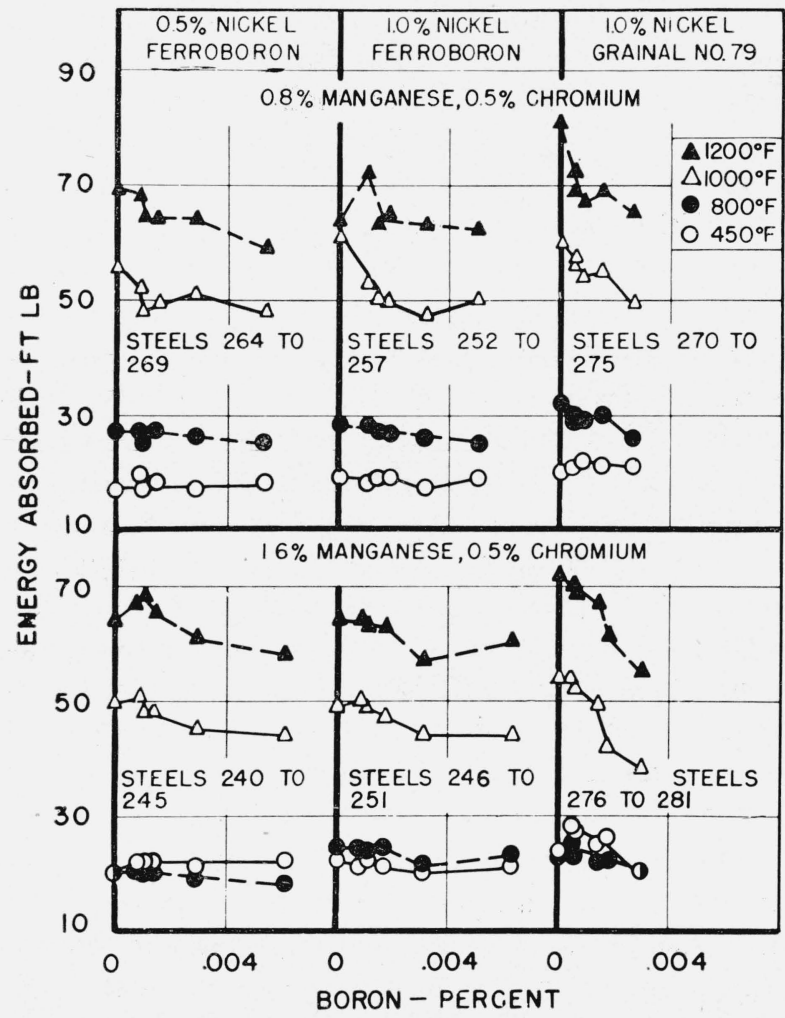

Figure 47.-Influence of boron on the notch toughness at room temperature of experimental nickel-chromium stecis containing 0.3 percent of carbon and 0.8 or 1.6 percent of manganese.

The chemical composition of the steels is given in table 6. The Charpy specimens were quenched from $1,600^{\circ} \mathrm{F}$ in water (steels with $0.8 \% \mathrm{Mn}$ ) or oil (steels with $1.6 \% \mathrm{Mn}$ ) and tempered as indicated.

The notch toughness at $+70^{\circ} \mathrm{F}$ of the fully hardened 0.8 percent manganese steels increased slightly with change in tempering temperature from $450^{\circ}$ to $800^{\circ} \mathrm{F}$ but the toughness of the 1.6 percent manganese steel was not improved by this change in temperature. However, the notch toughness at $+70^{\circ} \mathrm{F}$, of all the steels increased rapidly with further increase in the tempering temperature (decrease in hardness).

Additions of boron had no marked effect on the notch toughness at $+70^{\circ} \mathrm{F}$ of the steels tempered alike at $450^{\circ}$ or $800^{\circ} \mathrm{F}$ (fig. 47 ), but the trend was for the toughness of the steels tempered at $1,000^{\circ}$ or $1,200^{\circ} \mathrm{F}$ to decrease with increase in boron from about 0.001 to 0.006 percent. This

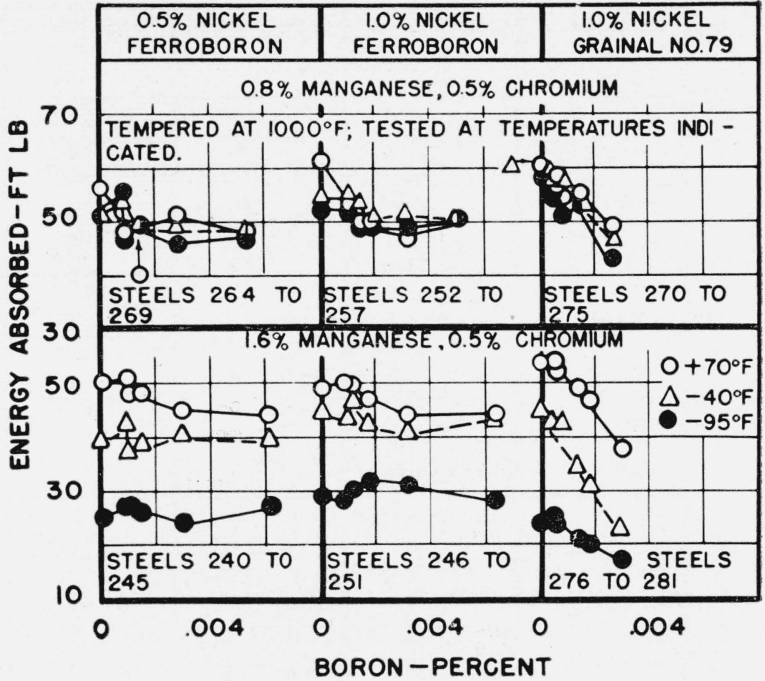

FiguRE 48.-Influence of boron on the notch toughness at $+70^{\circ},-40^{\circ}$, and $-95^{\circ} \mathrm{F}$ of experimental nickel-chromium steels containing 0.3 percent of carbon and 0.8 or 1.6 percent of manganese.

The chemical composition of the steels is given in table 6. The Charpy specimens were quenched from $1,600^{\circ} \mathrm{F}$ in water (steels with $0.8 \% \mathrm{Mn}$ ) or oil (steels with $1.6 \% \mathrm{Mn}$ ) and tempered at $1,000^{\circ} \mathrm{F}$.

trend for the toughness to decrease with increase in boron content was especially noticeable in the steels prepared with Grainal No. 79.

The notch toughness at $-40^{\circ}$ and $-95^{\circ} \mathrm{F}$ of the steels tempered at $1,000^{\circ} \mathrm{F}$ (fig. 48) was not appreciably affected by the additions of boron with Ferroboron, whereas the toughness at these temperatures decreased with increase in boron of the steels prepared with Grainal. A noteworthy feature is the high-notch toughness at low temperatures of the nickel-chromium steels containing 0.8 percent of manganese with and without boron additions made with either Ferroboron or Grainal No. 79. The values for notch toughness of these steels with 0.5 percent of nickel were of the same order of magnitude as those obtained with 1.0 percent of nickel. The notch toughness at $-95^{\circ}$ $\mathrm{F}$, however, was lowered appreciably by increasing the manganese from 0.8 to 1.6 percent.

7. Chromium-molybdenum.-The results of the Charpy tests made on the chromium-molybdenum steels listed in table 7 are summarized in figures 49 and 50 .

In general, the notch toughness at $+70^{\circ} \mathrm{F}$ of the four heats with relatively high hardenability (steels 210 to 215,222 to 227,234 to 239,294 to 299) decreased slightly with change in tempering 
temperature from $450^{\circ}$ to $800^{\circ} \mathrm{F}$, whereas the toughness of the remaining heats (lower hardenability) either was not affected or was improved by this change in temperature. As is to be expected, the notch toughness of all the steels increased with increase in tempering temperature irom $800^{\circ}$ to $1,200^{\circ} \mathrm{F}$.

The general trend was for the notch toughness at $+70^{\circ} \mathrm{F}$ of the steels fully hardened and then tempered at $450^{\circ}$ to $1,200^{\circ} \mathrm{F}$ to be improved slightly by low boron (additions with either Ferroboron or Grainal No. 79), but with about 0.001 percent or greater the notch toughness was either not further affected or was lowered (fig. 49). With specimens tempered at $1,000^{\circ}$ or $1,200^{\circ} \mathrm{F}$, the notch toughness values at $+70^{\circ} \mathrm{F}$ of many

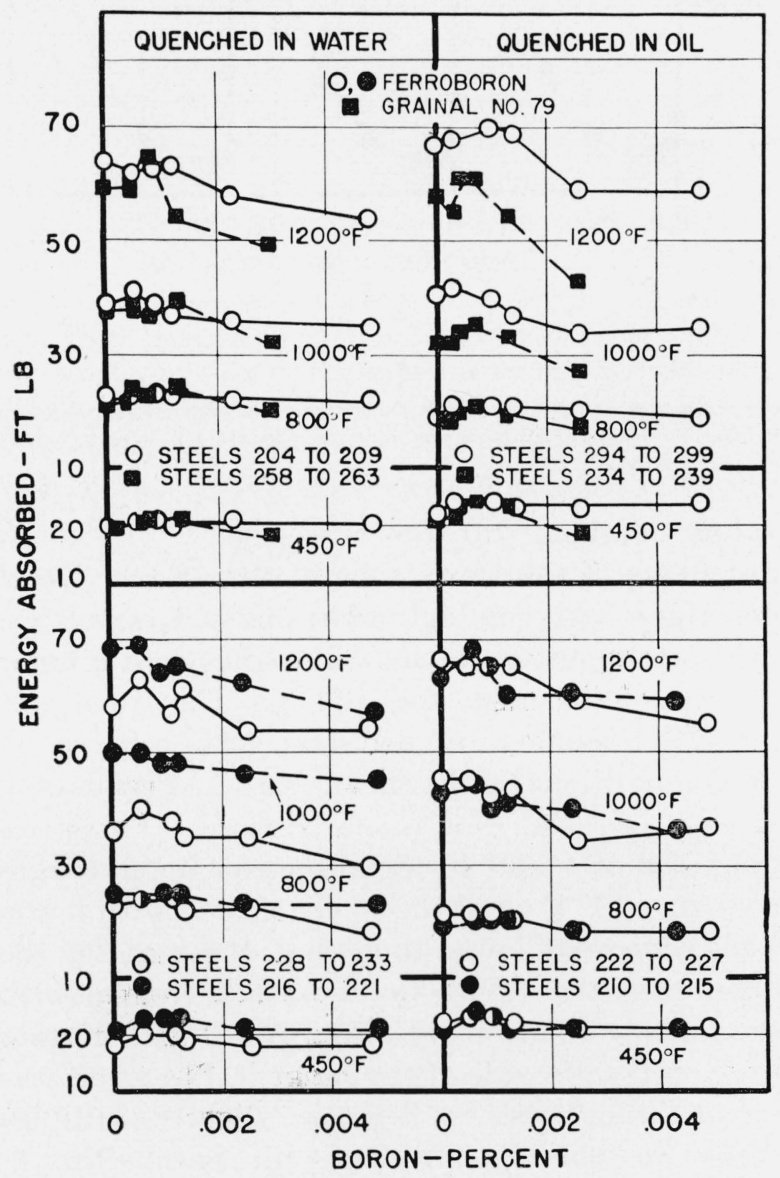

FigURE 49.-Influence of boron on the notch toughness at room temperature of experimental chromium-molybdenum steels containing 0.3 percent of carbon and 0.8 or 1.6 percent of manganese.

The chemical composition of the steels is given in table 7 . The Charpy specimens were quenched from $1,600^{\circ} \mathrm{F}$ in water or oil and tempered as indicated.

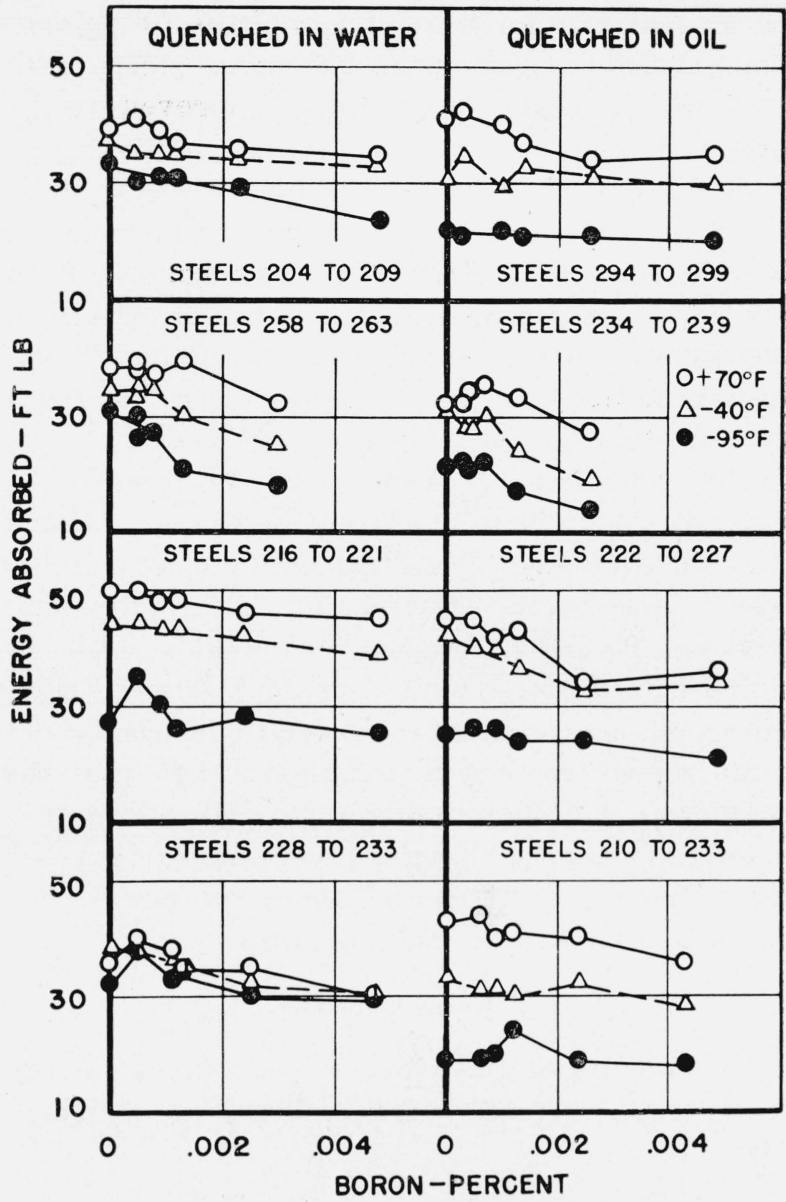

FiguRE 50.-Influence of boron on the notch toughness at $+70^{\circ},-40^{\circ}$, and $-95^{\circ} F$ of experimental chromiummolybdenum steels containing 0.3 percent of carbon and 0.8 or 1.6 percent of manganese.

The chemical composition of the steels is given in table 7. Steels 204 to 233 and 234 to 299 treated with Ferroboron; steels 234 to 239 and 258 to 263 treated with Grainal No. 79. The Charpy specimens were quenched from $1,600^{\circ} \mathrm{F}$ in water or oil and tempered at $1,000^{\circ} \mathrm{F}$.

of the steels with about 0.003 to 0.005 percent of boron were appreciably lower than those of the base steels.

The notch toughness at room temperature of the steels with 1.6 percent of manganese, 0.5 percent of chromium, with and without boron, was not appreciably enhanced by variations in molybdenum from 0.04 to 0.33 percent. It should be pointed out, however, that all the specimens were tempered alike at each temperature, and the hardness after tempering at $1,000^{\circ}$ or $1,200^{\circ} \mathrm{F}$ increased with the molybdenum content; the relatively higher hardness of the molybdenum steels, therefore, would tend to lower their toughness. 
In general, the notch toughness of the 1.6 percent manganese, 0.3 percent molybdenum steels, with and without boron, was slightly improved by the presence of 0.5 percent of chromium, but a change from 0.5 to 0.75 percent of chromium was without effect in the steels containing 0.15 percent of molybdenum. Increasing the manganese from 0.8 to 1.6 percent in the steels with 0.5 percent of chromium and 0.3 percent of molybdenum appeared to improve the toughness in certain heats and in others to decrease the toughness.

The addition of boron with Ferroboron or Grainal No. 79 usually was not beneficial to notch toughness at any of the test temperatures of the steels tempered at $1,000^{\circ} \mathrm{F}$ (fig. 50). The trend was for the notch toughness at $+70^{\circ},-40^{\circ}$, or $-95^{\circ} \mathrm{F}$ to decrease with increase in boron. Similar trends also occurred with variations in molybdenum, chromium, and manganese, except that the toughness at room temperature was not appreciably affected by changes in chromium or in the manganese content of the steels comprising the heats treated with Ferroboron.

\section{(b) Commercial Steels}

The results of the Charpy tests made on the steels listed in table 8 are summarized in figures 51 to 54 .

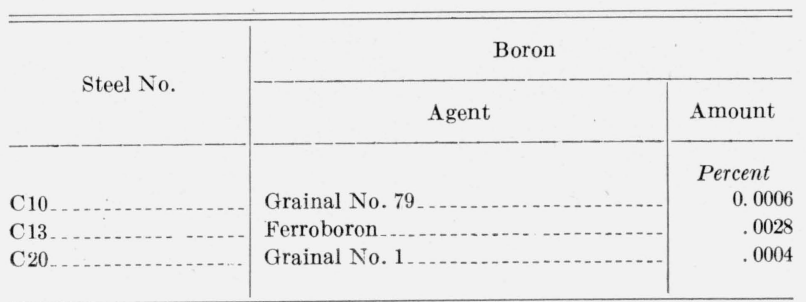

The notch toughness at room temperature of the fully hardened steels, varied with the tempering temperature as illustrated in figure 51. In general, the notch toughness decreased with increase in tempering temperature from $400^{\circ}$ to $600^{\circ} \mathrm{F}$ and thereafter increased with the temperature. The spread in values for the steels of each group, i. e., treated with the same intensifier, when heattreated alike varied to some extent with the tempering temperature. For steels tempered at $1,200^{\circ} \mathrm{F}$ (fig. 52), the notch toughness at $+70^{\circ} \mathrm{F}$ was not materially affected by the additions of boron with Ferroboron, Grainal No. 1, or Borosil (note that in figs. 52 and 53 horizontal lines are drawn through the points representative of the

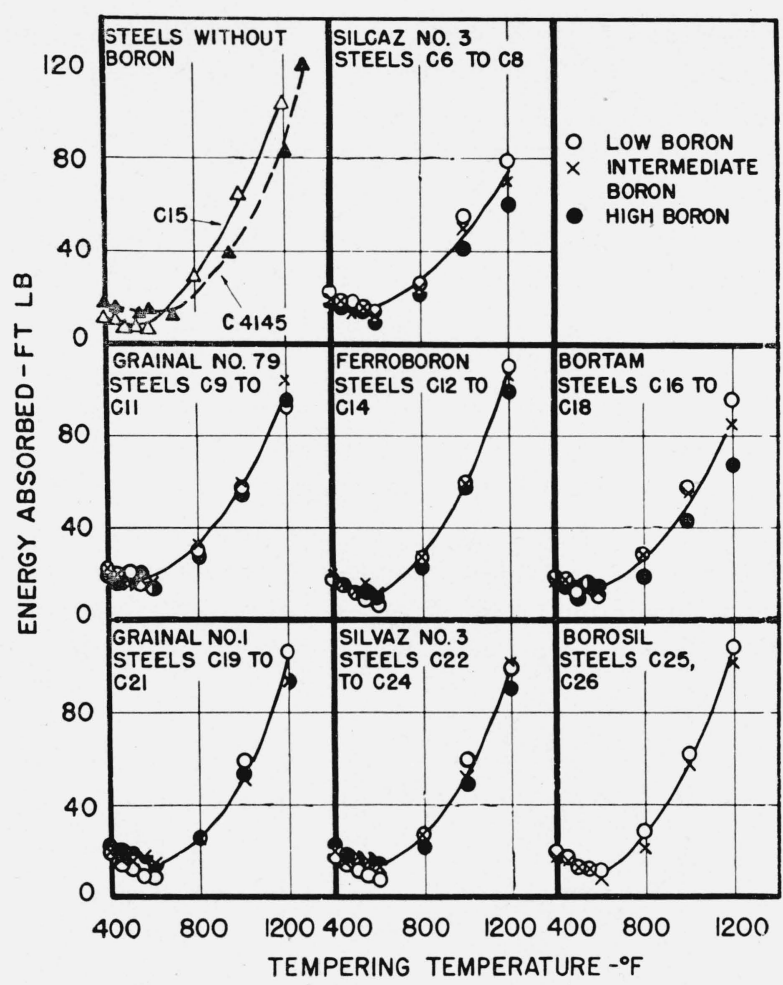

FIGURE 51.-Effect of tempering temperature on the notch toughness at room temperature of commercial steels containing 0.45 percent of carbon.

The chemical composition of the steels is given in table 8 and intensifiers in table 9. The Charpy specimens were quenched from $1,550^{\circ} \mathrm{F}$ in oil and tempered as indicated.

values obtained with the base steel). The notch toughness of the steels treated with Silcaz No. 3 and those with the high additions of Grainal No. 79, Bortam, or Silvaz No. 3 was somewhat inferior to that of the base steel (C15). The trend was for the toughness to decrease with increase in boron additions with Silcaz No. 3, Ferroboron, Bortam, Grainal No. 1, and Borosil. For steels tempered at $1,000^{\circ} \mathrm{F}$, the values for notch toughness at $+70^{\circ} \mathrm{F}$ of all the steels treated with boron were somewhat lower than that obtained for the base steel; the values for the steels treated with the highest additions of Silcaz No. 3 and Bortam were on the low side of the range. The trend was for the toughness to decrease slightly with increase in boron additions with Silcaz No. 3, Bortam, Silvaz No. 3, and Borosil. For the steels tempered at $800^{\circ} \mathrm{F}$ and treated with the highest additions of Silcaz No. 3, Bortam, Silvaz No. 3, and Borosil, the values obtained for notch toughness at $+70^{\circ} \mathrm{F}$ were on the low side of the range whereas those for the steel treated with the inter- 


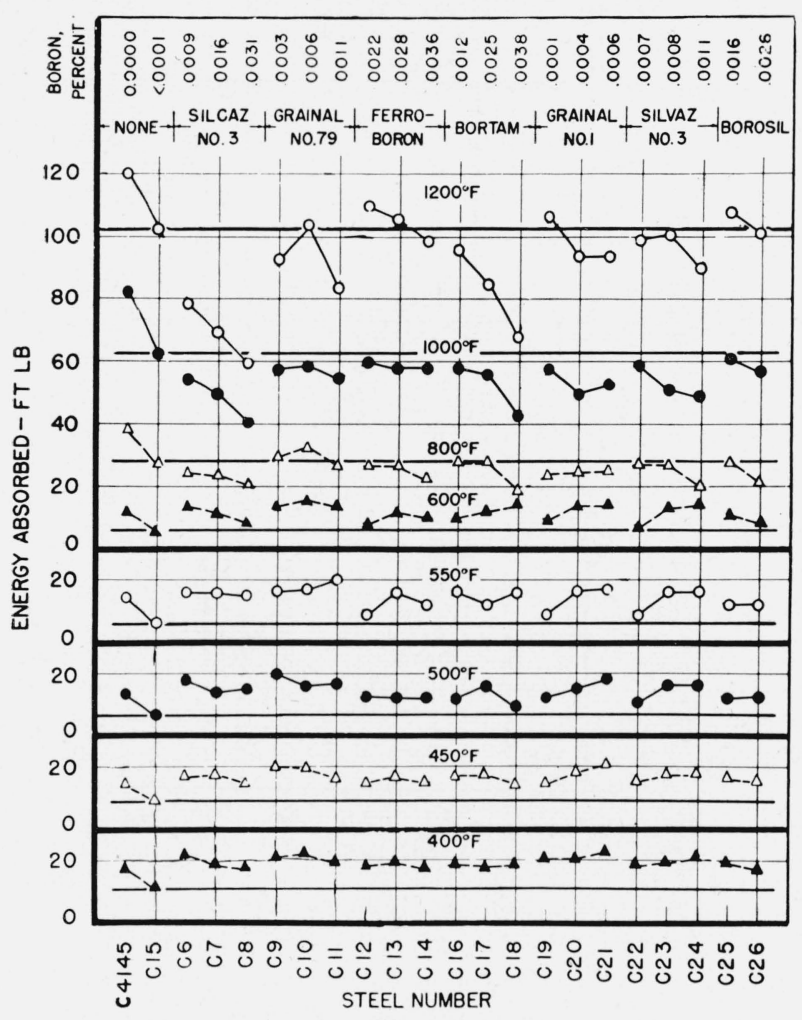

FiguRE 52.- Notch toughness at room temperature of commercial steels as quenched and tempered.

The chemical composition of the steels is given in table 8 . The Charpy specimens were quenched from $1,550^{\circ} \mathrm{F}$ in oil and tempered as indicated.

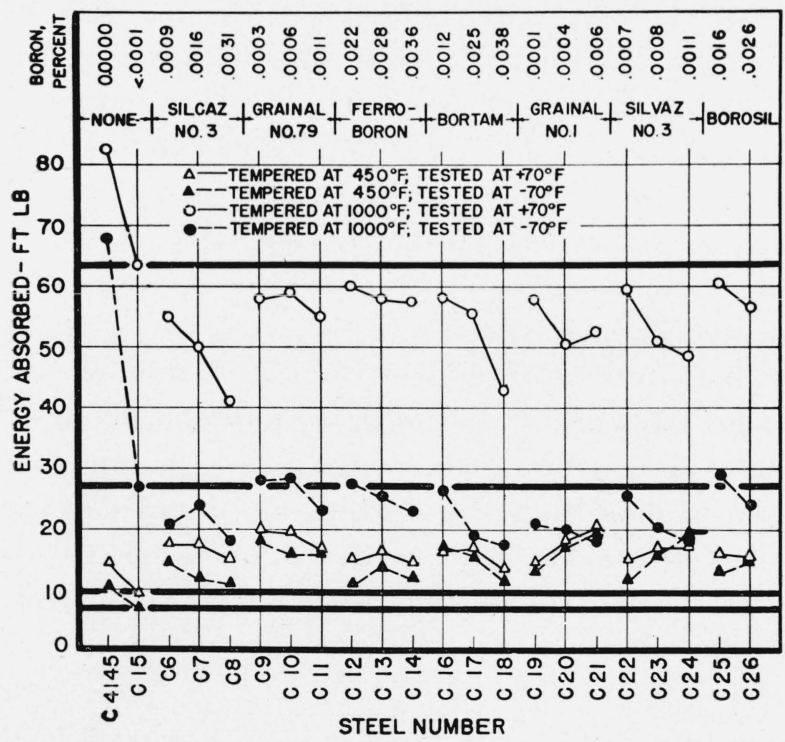

Figure 53.-Notch toughness at $+70^{\circ}$ and- $70^{\circ} F$ of commercial steels as quenched and tempered.

The chemical composition of the steels is given in table 8. The Charpy specimens were quenched from $1,550^{\circ} \mathrm{F}$ in oil and tempered at $450^{\circ}$ or $1,000^{\circ} \mathrm{F}$ as indicated.

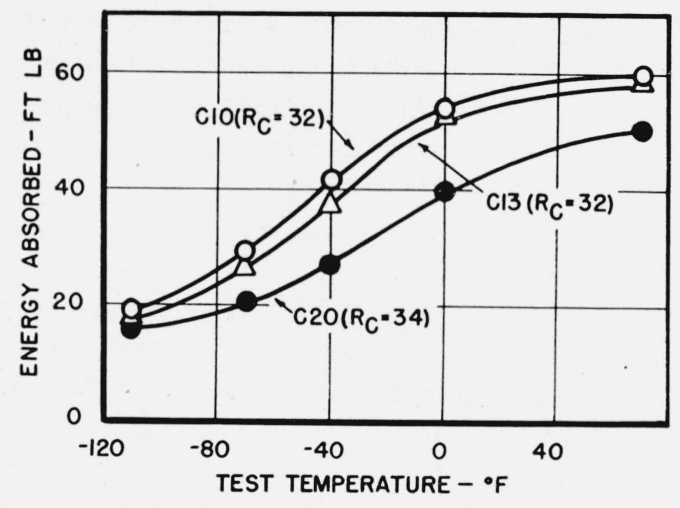

Figure 54.-Effect of test temperature on the notch toughness of some boron-treated commercial steels as quenched and tempered.

The chemical composition of the stcels is given in table 8. The Charpy specimens were quenched from $1,550^{\circ} \mathrm{F}$ in oil and tempered at $1,000^{\circ} \mathrm{F}$.

mediate addition of Grainal No. 79 were on the high side. When tempered in the range of $400^{\circ}$ to $600^{\circ} \mathrm{F}$, the notch toughness at room temperature of many of the steels treated with boron shows a definite improvement that is believed to be significant.

The notch toughness of all the special steels tempered at $1,000^{\circ} \mathrm{F}$ decreased appreciably with change in test temperature from $+70^{\circ}$ to $-70^{\circ} \mathrm{F}$ (fig. 53). Furthermore, the addition of boron with the various intensifiers was not beneficial to low-temperature toughness. For steels tempered at $450^{\circ} \mathrm{F}$, the toughness was, in general, only slightly lowered by this change in test temperature and the values at $-70^{\circ} \mathrm{F}$ for all steels with boron were higher than that of the base steel without boron.

The influence of test temperature on the notch toughness of steels $\mathrm{C} 10, \mathrm{C} 13$, and $\mathrm{C} 20$ fully hardened and then tempered at $1,000^{\circ} \mathrm{F}$ is shown in figure 54. Although the energy-test temperature curves for the three steels fall at different levels, the slopes for steels $\mathrm{C} 10$ and $\mathrm{C} 13$ were quite similar and somewhat steeper than that for steel C20. The notch toughness of each steel was not materially affected by a change in test temperature from $+70^{\circ}$ to $0^{\circ} \mathrm{F}$, but with further decrease to $-70^{\circ} \mathrm{F}$, the toughness decreased rather rapidly. The order of merit of the steels did not change throughout the entire range investigated, all steels had values within the range of 15 to $20 \mathrm{ft} / \mathrm{lb}$ at $-110^{\circ} \mathrm{F}$. It should be pointed out that the hardness value for steel $\mathrm{C} 20$, which contained a small 
amount of vanadium, was on the average two Rockwell $\mathrm{C}$ points higher than that of the other steels tempered alike at $1,000^{\circ} \mathrm{F}$, and this is a factor that would tend to lower its toughness.

\section{(c) Discussion}

As Charpy impact tests were not carried out on specimens of the experimental 0.20 and 0.30 percent carbon steels fully hardened and then tempered within the range of $450^{\circ}$ to $600^{\circ} \mathrm{F}$ (some tests were made with 0.45 carbon steels tempered at $600^{\circ} \mathrm{F}$ ), the exact shape of the energy-tempering temperature curve was not established for these steels in this temperature range. It is possible, therefore, that some of the experimental steels (especially the deeper hardening types with 1.6 percent of manganese) would show a decrease in notch toughness at room temperature with an increase in tempering temperature from about $450^{\circ}$ to $600^{\circ} \mathrm{F}$, similar to the commercial steels.

The relation of notch toughness at room temperature to hardness (Rockwell C) of quenched and tempered 0.3 percent carbon steels without boron is shown in figure 55. Except for the omission of the high-nitrogen and nonkilled steels, the average hardness and notch toughness values for each base steel with 0.3 percent of carbon, were used in establishing this relationship. The average values for all the steels are indicated by the position of the curve and the spread by the vertical lines. The values for the high-ritrogen steels, with and without boron, and high boron steels treated with Grainal No. 79 often were in the lower part or below this range, whereas the values for the steels with low boron were usually well within, and when treated for high hardness, above the range.

Some idea of the relative hardenability and notch toughness of the experimental and commercial steels each with 0.45 percent of carbon and 1.6 percent of manganese may be obtained from the results summarized in table 12 .

The experimental steel without boron was slightly deeper hardening than the commercial steel, but with similar additions of boron the order of superiority was reversed. These results, therefore, indicate that addition of boron in the ingot mold of relatively large capacity is equally as, or more, effective than in the furnace in enhancing the hardenability of steels of the selected type composition. Furthermore, the trend was for the

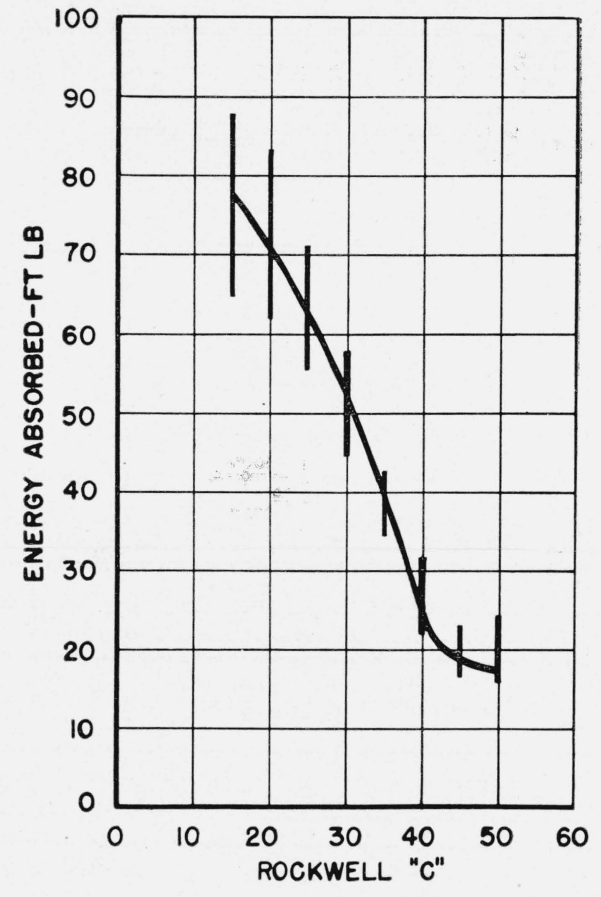

FIgURE 55.-Relation of notch toughness at room temperature to Rockwell $C$ hardness of experimental steels containing 0.3 percent of carbon as fully quenched and tempered.

The curve represents the relationship between the average notch toughness and hardness values and the vertical lines the approximate range in values for notch toughness. (The values for all the base steels (without boron) with 0.3 percent of carbon, listed in tables 1 to 7 , are included in this chart except those with high nitrogen and those not deoxidized with aluminum.)

values for notch toughness at room temperature of the steels as fully hardened and tempered at low temperatures $\left(450^{\circ}\right.$ and $\left.600^{\circ} \mathrm{F}\right)$ to be slightly higher in the commercial than in the experimental steels and considerably higher when tempered alike at $1,000^{\circ} \mathrm{F}$. The notch toughness at $-70^{\circ} \mathrm{F}$ of specimens tempered at $1,000^{\circ} \mathrm{F}$ was also greater in the commercial steels.

The notch toughness of the fully hardened and tempered steels, varied with the hrrdness (tempering temperature), test temperature, boron content, composition of intensifiers; in the case of the experimental steels the notch toughness also varied with the base composition and state of deoxidation.

The addition of small amounts of boron was often beneficial to notch toughness at room temperature of the stee's when fully hardened and tempered at low temperatures (high-hardnesses), but the presence of boron, especially as relatively high additions with intensifiers containing tita- 
TABLE 12.-Comparison of hardenability and notch toughness of experimental and commercial steels with 0.45 percent of carbon and 1.6 percent of manganese

\begin{tabular}{|c|c|c|c|c|c|c|c|c|c|c|c|c|c|c|c|}
\hline \multirow{4}{*}{ Steel No. } & \multicolumn{6}{|c|}{ Composition, percent } & \multirow{2}{*}{\multicolumn{2}{|c|}{$\begin{array}{c}\text { Hardenability } \\
\text { 16ths inch from } \\
\text { water-cooled } \\
\text { end for Rock- } \\
\text { well C value } \\
\text { of-- }\end{array}$}} & \multicolumn{7}{|c|}{ Charpy impact specimen ${ }^{1}$ tempered at- } \\
\hline & \multirow{3}{*}{ C } & \multirow{3}{*}{ Mn } & \multirow{3}{*}{$\mathrm{P}$} & \multirow{3}{*}{$\mathrm{S}$} & \multirow{3}{*}{$\mathrm{Si}$} & \multirow{3}{*}{$\mathrm{B}^{2}$} & & & \multicolumn{2}{|c|}{$450^{\circ} \mathrm{F}$} & \multicolumn{2}{|c|}{$600^{\circ} \mathrm{F}$} & \multicolumn{3}{|c|}{$1,000^{\circ} \mathrm{F}$} \\
\hline & & & & & & & \multirow[t]{2}{*}{50} & \multirow[t]{2}{*}{42} & \multirow{2}{*}{$\begin{array}{l}\text { Hard- } \\
\text { ness, } R_{C}\end{array}$} & \multirow{2}{*}{$\begin{array}{c}\text { Energy } \\
\text { absorbed, } \\
\text { ft-lb at } \\
+70^{\circ} \mathrm{F}\end{array}$} & \multirow{2}{*}{ Hard- } & \multirow{2}{*}{$\begin{array}{l}\text { Energy } \\
\text { absorbed, } \\
\text { ft-lb at } \\
+70^{\circ} \mathrm{F}\end{array}$} & \multirow{2}{*}{$\begin{array}{c}\text { Hard- } \\
\text { ness, } R_{C}\end{array}$} & \multicolumn{2}{|c|}{$\begin{array}{l}\text { Energy } \\
\text { absorbed, } \\
\text { ft-lb at- }\end{array}$} \\
\hline & & & & & & & & & & & & & & $+70^{\circ} \mathrm{F}$ & $-70^{\circ} \mathrm{F}$ \\
\hline \multicolumn{16}{|c|}{ EXPERIMENTAL } \\
\hline 5. & 0.47 & 1.56 & 0.011 & 0.020 & 0.24 & None & 5.5 & 7.0 & 54 & 6.8 & $51^{\circ}$ & 5.4 & 33 & 39 & 17.9 \\
\hline 6 & .47 & 1. 58 & & & .23 & 0.0015 & 9.5 & 11.5 & 55 & 12.8 & 50 & 11.2 & 33 & 38 & 17 \\
\hline 7 & .46 & 1. 57 & & & .23 & .0033 & 7.1 & 8.6 & 54 & 12.9 & 50 & 7.3 & 33 & 41 & 20.5 \\
\hline 8 & .44 & 1.57 & & & .23 & .0062 & 10.7 & 12.5 & 54 & 12.6 & 50 & 8.5 & 32 & 41 & 17.3 \\
\hline
\end{tabular}

COMMERCIAL

\begin{tabular}{|c|c|c|c|c|c|c|c|c|c|c|c|c|c|c|c|}
\hline $\mathrm{C} 15_{\ldots}$ & 0.43 & 1.58 & 0.020 & 0.019 & 0.31 & None & 4.4 & 5.8 & 53 & 9.3 & 50 & 6. 6 & 32 & 63 & 27.0 \\
\hline $\mathrm{C} 12 \ldots$ & .43 & 1.56 & .020 & .019 & .31 & 0.0022 & 13.0 & 15.4 & 53 & 14.9 & 50 & 7.5 & 31 & 60 & 27.6 \\
\hline $\mathrm{C} 13 \ldots$ & .43 & 1.58 & .020 & .017 & .31 & .0028 & 13. 2 & 15.6 & 54 & 16.4 & 50 & 11.5 & 32 & 58 & 25.6 \\
\hline C14 & .43 & 1.59 & .018 & .019 & .32 & .0036 & 13. 2 & 16. 3 & 53 & 14.6 & 50 & 9.6 & 31 & 58 & 22.8 \\
\hline
\end{tabular}

1 The specimens, initially normalized, were heated at $1,550^{\circ} \mathrm{F}$ for 1 hour and quenched in still oil at $100^{\circ}$ to $120^{\circ} \mathrm{F}$. The quenched specimens were transferred, without cooling to room temperature, to a furnace at the indicated temperature, heid at this temperature for 1 hour and then cooled in air. Charpy tests were made in duplicate. Refer to text for details of the preparation of specimens and testing procedures.

2 Boron additions were made with Ferroboron; values by chemical analysis.

nium was usually either without effect or was detrimental to notch toughness at room and subzero temperatures when the steels were tempered at high temperatures.

The notch toughness of the following steels fully hardened and tempered at $1,000^{\circ} \mathrm{F}$ was not affected appreciably by a change in test temperature from room to $-95^{\circ} \mathrm{F}$.

\section{Tensile}

Tensile tests were made on normalized and on heat-treated specimens of many of the experimental and several of the commercial steels. As these data were presented in some detail in the original reports [5 to 11$]$ to the sponsor, only a summary of the results will be included in the present report in order to show the characteristic

\begin{tabular}{|c|c|c|c|c|c|c|c|}
\hline $\mathrm{C}$ & Mn & $\mathrm{Ni}$ & $\mathrm{Cr}$ & Mo & $\mathrm{N}$ & B & Remarks \\
\hline$\%$ & $\%$ & $\%$ & $\%$ & $\%$ & $\%$ & $\%$ & \\
\hline 0.3 & 0.8 & 0.4 to 1.1 & 0 & 0 & Low $\ldots$ & 0 to 0.005 & Boron additions as Ferroboron. \\
\hline .3 & .8 & & .25 to .75 & 0 & Low to high & 0 to .005 & Do. \\
\hline .3 & .8 & .4 to 1.0 & .5 & 0 & Low $\ldots \ldots$ & 0 to .005 & $\begin{array}{l}\text { Boron additions as Ferroboron } \\
\text { or Grainal No. } 79 .\end{array}$ \\
\hline .3 & 1. 25 & 0 & .25 & 0 & $\ldots \ldots$ do & 0 to .003 & Do. \\
\hline .3 & 1. 6 & 0 & 0 & 0 & 0.015 & 0 to .005 & Boron additions as Ferroboron. \\
\hline .3 & 1. 6 & 0 & 0 & 0.3 & 0.005 & 0 to .001 & $\begin{array}{l}\text { Boron additions as Ferroboron, } \\
\text { Grainal No. } 79 \text { or Silcaz } \\
\text { No. } 3 .\end{array}$ \\
\hline .3 & 1. 6 & 0 & 0 & 0.3 & Low $\ldots \ldots$ & 0 to .005 & Boron additions as Ferroboron. \\
\hline
\end{tabular}

The notch toughness at low temperatures of the above steels, especially those containing 0.8 percent of manganese and nickel, and the relatively high notch toughness at room temperature of boron-treated steels heat-treated for high hardness values are considered significant factors that may be of importance industrially. 
trends due to boron and other elements on the tensile properties.

The beneficial effects of alloying elements on the mechanical properties of structural steels are fully obtained only when they are in the heattreated condition; that is, when fully hardened and tempered. The results of the tensile tests made on the steels in the annealed or normalized condition, therefore, are considered to be of minor importance. Obviously, the tensile properties of normalized steels will vary with the rate of cooling from the austenitizing temperature and with the presence or absence of elements that confer the property of deep-hardening, such as manganese, chromium, and molybdenum. No marked or consistent improvement in the tensile properties of the steels as annealed or as normalized could be attributed to the addition of boron. However, an interesting feature of the test results obtained with the commercial steels was the combination of greater yield and tensile strengths and reduction of area of each steel as normalized (cooled in air) as compared with the same steel as annealed (cooled slowly in furnace).

\section{(a) Experimental Steels}

A general summary of the results of tests made on tensile specimens of the experimental steels, containing 0.3 percent of carbon, as quenched from the usually recommended temperature in water (or oil, fully hardened) and then tempered alike at $450^{\circ}, 600^{\circ}, 800^{\circ}, 1,000^{\circ}$, or $1,200^{\circ} \mathrm{F}$ follows:

1. Carbon-manganese (steels 1 to 4,13 to 20 , table 1).-The tensile properties were not materially affected by boron (additions with Ferroboron) in steels with $0.8,1.25$, or 1.6 percent of manganese, except possibly a slight improvement in the reduction of area due to boron in the 0.8 and 1.25 percent manganese steels and a decrease in yield and tensile strengths of 1.25 and 1.6 percent of manganese steels with the higher additions of boron when tempered at $450^{\circ} \mathrm{F}$.

2. Deoxidation practice (all steels listed in table 2).- The tensile properties of these steels with 1.6 percent of manganese were not significantly affected by boron, additions with Ferroboron, Grainal No. 79 or Silcaz No. 3, or by variation in deoxidation practice used. (There was a slight trend for the reduction of area to be improved by boron in some of the steels when tempered at $450^{\circ} \mathrm{F}$.)

3. Nitrogen (all steels listed in table 3).-Variation in nitrogen had no marked effect on the tensile properties, except for a decrease in ductility with increase in nitrogen in steels with about 0.003 percent of boron and 0.10 percent of titanium (steels 141, 153, and 185) when tempered at $600^{\circ} \mathrm{F}$.

The effects of titanium, chromium, and zirconium on the tensile properties of high-nitrogen steels with about 0.0015 percent of boron varied to some extent with the tempering temperatures used. When tempered at $450^{\circ} \mathrm{F}$ for relatively high strengths, the yield and tensile strengths of steels with titanium decreased with increase in concentrations of this element, whereas the effects due to variation in chromium (without titanium or zirconium) were negligible. The strengths of the chromium steels, however, were slightly decreased by small additions of titanium. The reduction of area increased with small additions of titanium and then decreased with the higher additions. The reduction of area of the steels with about 0.2 or 0.45 percent of zirconium was also superior to that with lower or higher additions. When tempered at $1,200^{\circ} \mathrm{F}$ for relatively low strength, variations in titanium or zirconium had no significant effect on the yield and tensile strengths, but the strengths of the chromium steels were superior and the ductility of the steels containing relatively high titanium or chromium was somewhat inferior to those of the base steels.

4. Nickel (all steels listed in table 4).-The tensile properties were not materially affected by nickel or boron, except for a slight improvement in reduction of area due to boron in steels with 0.35 or 0.6 percent of nickel when tempered at $450^{\circ} \mathrm{F}$.

5. Chromium (all steels listed in table 5).-The effect of chromium on the hardness and tensile properties of steels, with and without boron, varied with the tempering temperatures of the fully hardened steels. The yield and tensile strengths of the base steel when tempered at $450^{\circ}$ F were usually increased by the presence of chromium. However, the strengthening effects due to chromium were manifested after tempering at relatively high temperatures primarily through the action of chromium in resisting softening by 
tempering. There $w$ us a distinct trend for the strengths and hardness of the steels tempered at $1,200^{\circ} \mathrm{F}$ to increase with the chromium content, but this was often accompanied by a corresponding reduction in ductility (elongation and reduction of area). When tempered at either a low or high temperature, the strengths of the steels with high boron prepared with Ferroboron were usually lower than those of steels with 0 or 0.003 percent, whereas the values for the steels treated with Grainal No. 79 were generally on the upper side of the range.

6. Nickel-chromium (all steels listed in table 6).The effect of boron on the tensile properties of the nickel-chromium steels varied with the composition of the intensifiers and tempering temperatures. When tempered at $450^{\circ}$ or $600^{\circ} \mathrm{F}$, the trend was for the yield and tensile strengths of the steels prepared with Ferroboron to decrease with increase in boron, whereas these properties were not significantly affected by changes in boron additions with Grainal No. 79. When tempered at $1,200^{\circ} \mathrm{F}$, there was only a very slight trend for the strengths of the steels treated with Ferroboron to decrease with increase in boron, but the strengths of the Grainal-treated steels increased slightly with boron content. Variations in boron, however, had no marked effect on the ductility of the steels tested.

7. Chromium-molybdenum.-A study was not made of the tensile properties of the steels listed in table 7 .

\section{(b) Commercial Steels}

The two steels without boron and one steel prepared with each type of intensifier were selected for a study of the hardness and tensile properties as affected by quenching from $1,550^{\circ} \mathrm{F}$ in oil and then tempering at various temperatures. Steels C7, C10, C13, C15, C17, C20, C23, C26, and C4145, are reported in table 8 .

When the steels were tempered alike at temperatures varying from $450^{\circ}$ to $1,200^{\circ} \mathrm{F}$, the values for yield strength, tensile strength, and hardness were not materially affected by boron as is illustrated in figure 56. Similarly, the ductility (elongation and reduction of area) was not appreciably improved by boron when the steels were tempered at $800^{\circ} \mathrm{F}$ or higher. The spread in the values obtained in each of these properties was no greater than the variation to be expected from heat to heat, duplicate specimens, and testing procedure. However, when tempered at $450^{\circ}$ or $600^{\circ} \mathrm{F}$ for relatively high hardness, the ductility of the steel without boron was somewhat inferior to that of each of the boron-treated steels tested from this same heat. It should be pointed out that the ductility of the steel without boron, especially when tempered at $600^{\circ} \mathrm{F}$ was only slightly less than that of the steels containing

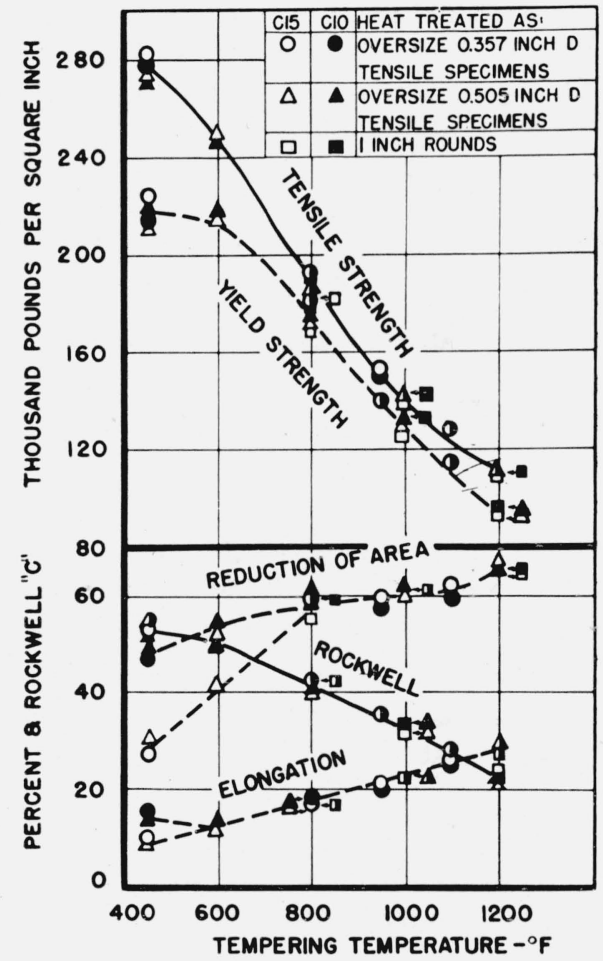

Figure 56.-Influence of tempering temperature on the tensile properties at room temperature of two commercial steels quenched as various size rounds.

The chemical composition of the steels is given in table 8. All tensile specimens were quenched from $1,550^{\circ} \mathrm{F}$ in oil, except the 1-inch rounds of steel $\mathrm{C} 15$, which were quenched in water. The yield strength was determined by the 0.2 -percent-offset method.

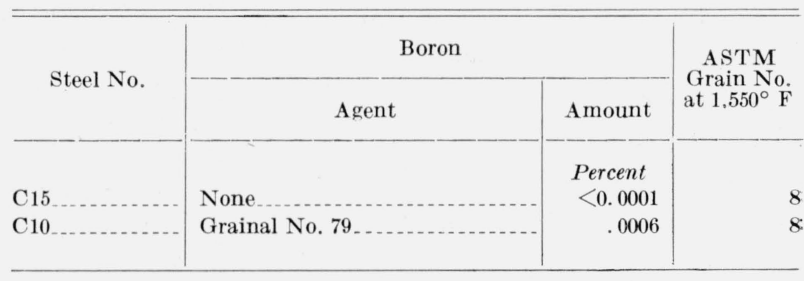


relatively high additions either with Ferroboron or Borosil (steels C15, C13, and C26).

\section{(c) Discussion}

Some of the trends reported for the experimental steels are not considered especially significant because the differences in values for the tensile properties were not greater than those that may be expected as arising from "quality" or from testing procedures. However, when both the experimental and commercial steels were quenched and tempered for high hardness there was some evidence that the ductility was improved by small additions of boron.

McQuaid [25] has expressed the opinion that maximum properties are attained under heattreating conditions in which the austenite is chemically homogeneous and it is cooled sufficiently fast to prevent the formation of free ferrite. Kinzel [26] pointed out that where low-tempering temperatures are involved, the nature of the martensite obtained in SAE 1300 series (plain manganese steels) is much akin to that obtained in plain carbon steels in which the normal manganese content is one-third to one-half as much. They apparently lack the homogeneity obtained with other alloy steels. This is true even in those sections that appear to be thoroughly hardened. However, the addition of relatively small amounts of nickel, chromium, or vanadium does permit the metallurgist to obtain optimum properties in fully hardened steels. The addition of boron is most useful in conjunction with the important amounts of other alloying elements, and it plays but a small role in steels that are not thoroughly quenched. Boron does not change the character of martensite.

Lorig [27] was of the opinion that the lower ductility of commercial steel $\mathrm{C} 15$ as quenched and then tempered at $450^{\circ} \mathrm{F}$ possibly might be due to the presence of free ferrite. He found that the ductility of quenched and tempered tensile specimens prepared from this steel increased with decrease in size (within certain limits) or decrease in amount of free ferrite.

Additional tests with tensile specimens of various diameters were carried out to determine whether the low ductility observed in this steel (C15) as quenched and tempered was due to incomplete hardening during the quench. Charpy (V-notch) impact and tensile specimens of steels
C10 and $\mathrm{C} 15$ were prepared, tested and examined microscopically in the usual manner. The results of the tensile tests summarized in table 13 indicated clearly that the presence of free ferrite in the structure produced by incomplete quenching steel C15 was detrimental to its ductility, when tempered at $450^{\circ}$ F. Previous results (fig. 56) indicated that this deleterious effect of free ferrite is minimized by increasing the tempering temperature to above about $800^{\circ} \mathrm{F}$. Both the fully hardened boron-treated steel $(\mathrm{C} 10)$ and the incompletely hardened nonboron steel (C15) had the same reduction of area when tempered alike at $800^{\circ}, 1,000^{\circ}$, or $1,200^{\circ} \mathrm{F}$.

The main role of boron in improving this ductility, therefore, appears to be due to its action in increasing hardenability (depth of hardening) and thereby ensuring complete hardening in a larger size than is possible in nonboron steels. That is, the tests were carried out on specimens of a "critical" size favorable for showing the improvement in hardenability due to boron. Obviously, it would be expected to find the difference in ductility to be nil if the steels were heat-treated in considerably larger sections where the suppression of appreciable amounts of free ferrite is impossible in the boron-treated steel.

The results of the Charpy tests (table 13), however, indicate that the elimination of free ferrite in the tempered specimens (specimens quenched in water, tempered $450^{\circ}$ or $600^{\circ} \mathrm{F}$ ) did not improve the notch toughness at room temperature. Again, steel $\mathrm{C} 10$ without the presence of free ferrite was somewhat tougher than steel $\mathrm{C} 15$ with or without free ferrite when tempered alike at $450^{\circ}$ or $600^{\circ} \mathrm{F}$.

The addition of boron had no effect on the resistance to softening by tempering of any of the quenched steels.

\section{Weldability}

Arc-welding tests were made on $1 / 2$-in.-thick plates of some of the carbon-manganese steels listed in table 1 (steels 1 to 4, 5, 8, 13, 16, 17, and $20)$. The plates were heat-treated (quenched from $1,575^{\circ}$ or $1,475^{\circ} \mathrm{F}$ in water and tempered at $1,000^{\circ}$ or $1,100^{\circ} \mathrm{F}$ ) for Vickers (Vn 30) hardness of 250 to 280 (Rockwell C 23 to 27 by conversion) prior to notching and assembling for welding. The welds were made by filling an open root, $V$-notch with metal from coated electrodes (Arcos Chro- 
TABLE 13.-Effect of cooling rate on the formation of free ferrite and the ductility as determined in tensile and impact tests of commercial steels $\mathrm{C} 10$ and $\mathrm{C} 15$

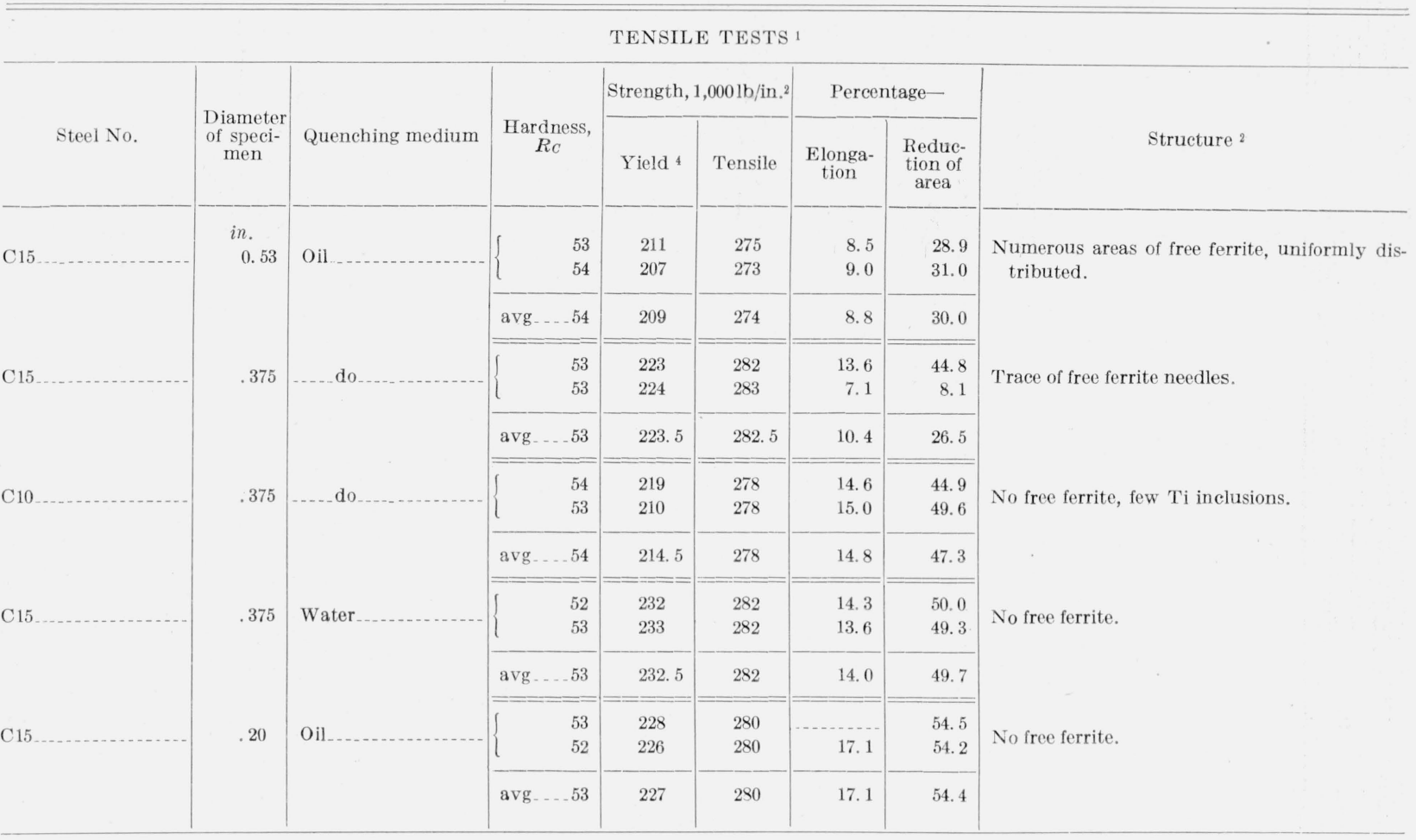

CHARPY TESTS ${ }^{3}$

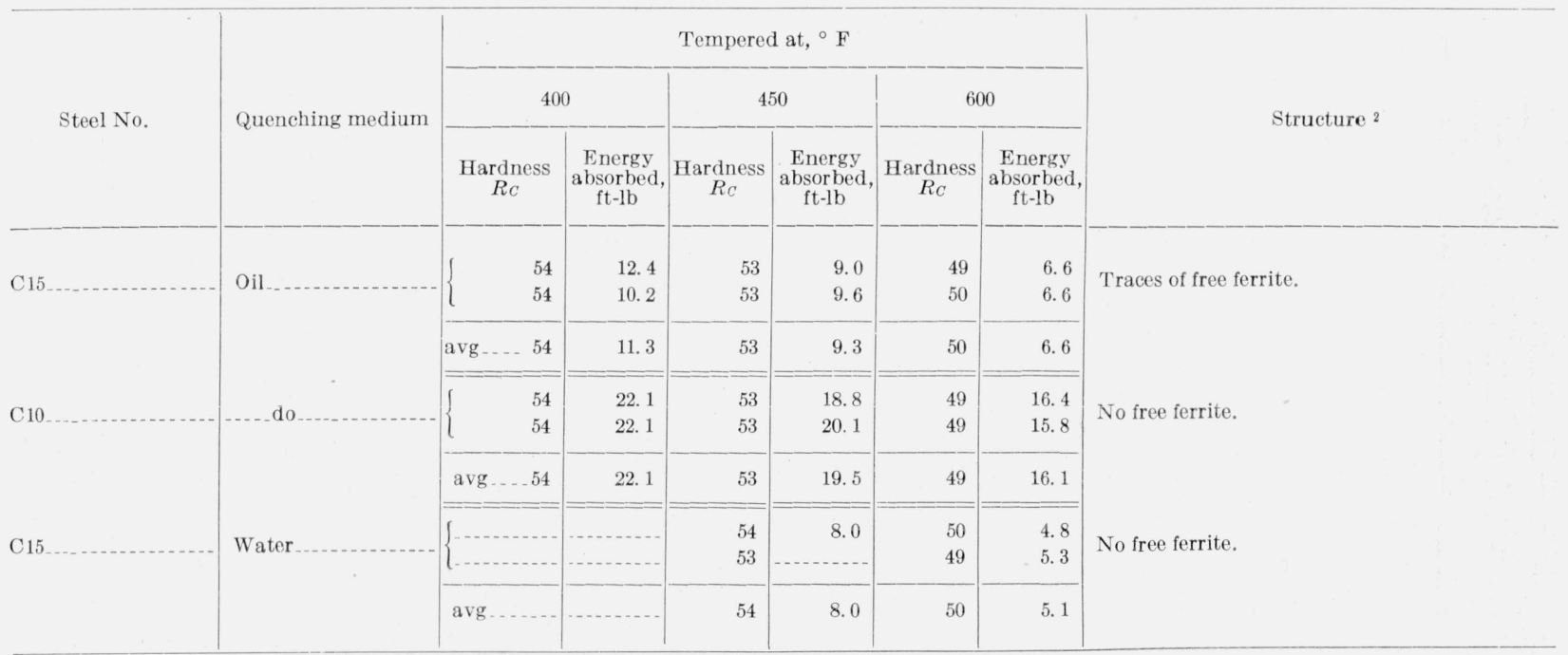

1 The specimens initially normalized at $1,650^{\circ} \mathrm{F}$ were heated at $1,550^{\circ} \mathrm{F}$ for 30 minutes and then quenched in still oil or by stirring vigorously in water. The quenched specimens were tempered at $450^{\circ} \mathrm{F}$ for $1 \mathrm{hr}$ and then cooled in air. Refer to text for procedures used in finishing the specimens to size and testing.

2 Tempered martensite.

3 Specimens, approximately $0.425 \mathrm{in}$. square by $2.16 \mathrm{in}$. long, were quenched from $1,550^{\circ} \mathrm{F}$ in oil or by stirring vigorously in water. The quenched specimens were tempered at temperature as indicated for $1 \mathrm{hr}$ and then cooled in air. Refer to text for procedure used in finishing the specimens to size (fig. 4 , D) and testing. Charpy tests were made at room temperature.

${ }^{4} 0.2$ percent offset method. 
mang $5 / 32^{-}$and $3 / 16^{-i n}$. diameters) containing 18 percent of chromium, 8 percent of nickel and 3.75 to 4.75 percent of manganese. All welds were made manually using direct current, reversed polarity and a split weave with a cover pass at an average speed of 8 to $9 \mathrm{in}$. per minute. Two specimens for metallographic examination and hardness surveys and two specimens for tensile testing were prepared from each plate after welding.

All the welds were considered as being of good quality and were apparently free from cracks, excessive porosity and slag inclusions. The structural features of the welds were similar in all the steels, and no correlation was found between boron, carbon, and manganese contents and the structures of either the heat-affected zone of the plate or weld metal.

The results of Vickers hardness surveys (30-kg load) showed that the maximum increase in plate hardness from welding occurred in the series of steels containing 0.4 percent of carbon, 1.6 percent of manganese (steels 5 and 8 with 0 and 0.006 percent of boron, respectively). These two steels had relatively high hardenability and contained the highest percentage of carbon. The steels with 0.3 percent of carbon, 0.8 or 1.6 percent of manganese, with or without 0.006 percent of boron, did not show an increase in plate hardness from welding.

Variations in boron, carbon, and manganese contents of the steels investigated had no appreciable effect on the maximum hardness value of the weld metal. Similarly, variations in boron or manganese in steels with 0.3 percent of carbon had no significant effect on the tensile properties (strength and ductility) of the welds, but the ductility of the steels with 0.45 percent of carbon, with or without boron, was inferior to that of the steels with 0.3 percent. The fracture of all the tensile specimens occurred in the weld metal; not in the plate metal.

The addition of boron, therefore, did not adversely affect the weldability of the steels as determined by the described tests.

\section{Recovery of Boron on Remelting}

Heats were prepared in an induction furnace in a magnesia-lined crucible without a slag under usual melting conditions, and other heats were similarly prepared, except that 1 percent of mill scale was included in the original charge. Each melt (about $70 \mathrm{lb}$ ) was deoxidized with 0.10 percent of aluminum just prior to adding 0.006 percent of boron, with either Ferroboron or Grainal No. 79 in the furnace and pouring into a steel mold. A part (6 to $20 \mathrm{lb}$ ) of each ingot was retained, and the remainder was remelted under the original conditions (regular melting practice or with $1 \%$ of mill scale), and additions of carbon, manganese, silicon, and 0.05 percent of aluminum were made to the melt (no boron was added) just prior to recasting. A part of each ingot was again retained, and the remainder was remelted using the same procedure as was used for the first remelts. The part of the ingots retained after each melt was forged into approximately 11/2-in. rounds. Analysis for carbon, manganese, and silicon was made on samples prepared from the ingots and boron on samples from the forged bars. The results, summarized in table 14 show that approximately 60 percent of the boron was retained after remelting in an induction furnace under normal conditions and about 25 or 50 percent (originally treated with Ferroboron or Grainal No. 79, respectively) under the oxidizing condition produced by the addition of mill scale. There was a further loss of boron on again remelting, but even under the oxidizing condition boron was retained in sufficient amounts to have a substantial influence on hardenability. Unfortunately, each of the elements, carbon, manganese, and silicon, varied over such wide ranges that the hardenability effect due to boron could not be accurately determined. Whether the boron existed in a suitable form to affect hardenability, therefore, could not be established by these tests.

\section{Summary}

Tests were made to determine the influence of varying amounts of boron additions made with different intensifiers (ferroalloys containing boron), on the cleanliness, structure, austenite, and McQuaid-Ehn grain sizes, hardenability, notch toughness (Charpy impact, V-notched specimen) at room and low temperatures and tensile properties at room temperature of experimental and commercial steels. The study was extended with some of the experimental steels to include the effect of variation in deoxidation practice on the above properties; the effect of boron on temperatures of transformations when slowly heated and cooled ( $A c$ and $A r)$ and when rapidly cooled $\left(A r^{\prime \prime}\right)$; 


\section{TABLE 14.-Recovery of boron on remelting}

The steels were prepared in an induction furnace at Battelle Memorial Institute. Each melt was deoxidized with 0.1 percent aluminum before making the boron addition in the furnace, and each remelt was again deoxidized with 0.05 percent aluminum just before pouring. Additions of carbon, manganese and silicon were made to some of the remelts.

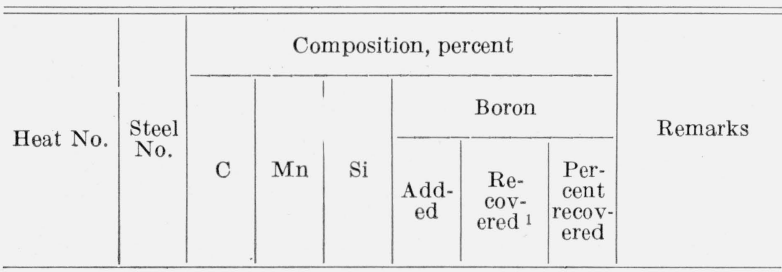

STRAIGHT MELTING; BORON ADDED AS FERROBORON

\begin{tabular}{r|r|r|r|r|r|r|r|l}
\hline $10107 \ldots \ldots$ & 282 & 0.27 & 1.88 & 0.48 & 0.006 & 0.0064 & 107 & Melt. \\
$10111 \ldots \ldots$ & 286 & .26 & 1.51 & .17 & None & .0037 & 58 & First remelt. \\
$10115 \ldots \ldots$ & 290 & .14 & 0.71 & .15 & None & .0002 & 5 & Second remelt. \\
\hline
\end{tabular}

STRAIGHT MELTING; BORON ADDED AS GRAINAL NO. 79

\begin{tabular}{r|r|r|r|r|r|r|r|l}
\hline $10108 \ldots \ldots$ & 283 & 0.27 & 1.73 & 0.29 & 0.006 & 0.0044 & 73 & Melt. \\
$10112 \ldots \ldots$ & 287 & .30 & 1.73 & .35 & None & .0027 & 61 & First remelt. \\
$10116 \ldots \ldots$ & 291 & .23 & 1.27 & .17 & None & .0010 & 37 & Second remelt. \\
\hline
\end{tabular}

MILL SCALE ADDED ${ }^{2}$; BORON ADDED AS FERROBORON

\begin{tabular}{r|r|r|r|r|r|r|r|l}
\hline $10109 \ldots \ldots$ & 284 & 0.24 & 1.23 & 0.18 & 0.006 & 0.0056 & 93 & Melt. \\
$10113 \ldots \ldots$ & 288 & .31 & 1.70 & .28 & None & .0013 & 23 & First remelt. \\
$10117 \ldots \ldots$ & 292 & .23 & 1.07 & .15 & None & .0003 & 23 & Second remelt. \\
\hline
\end{tabular}

MILL SCALE ADDED 2; BORON ADDED AS GRAINAL NO. 79

\begin{tabular}{r|r|r|r|r|r|r|r|l}
\hline $10110 \ldots \ldots$ & 285 & 0.26 & 1.37 & 0.20 & 0.006 & 0.0027 & 45 & Melt. \\
$10114 \ldots \ldots$ & 289 & .29 & 1.89 & .28 & None & .0014 & 52 & First remelt. \\
$10118 \ldots \ldots$ & 293 & .25 & 1.03 & .15 & None & .0002 & 14 & Second remelt. \\
\hline
\end{tabular}

1 Boron was determined by spectrographic analysis.

2 Addition of 1 percent mill scale was made in the furnace with each charge.

the effect of boron on weldability; and the recovery of boron on induction melting and remelting under normal and oxidizing conditions.

The procedures used for preparing the steels, test specimens, and carrying out the various tests are described in some detail, and the results are summarized in the text. The results of the determinations of the austenite and McQuaid-Ehn grain sizes, transformation temperatures, and the data obtained from the tensile and the welding tests are embodied in abridged form in the present paper. However, the complete data are included in restricted progress reports issued by the Office of Scientific Research and Development.

Approximately 250 experimental steels were made as "split" heats in an induction furnace and 20 commercial steels as a split heat in a basic open hearth furnace. Thus, a steel from each heat (except in a few special cases) was used as a basis for determining the magnitude of the effect of boron on the mechanical properties.

Boron was determined chemically by a distillation-colorimetric method by using phosphoric acid and turmeric with an accuracy of \pm 0.0002 percent of boron in the lower part of the range from 0.0005 to 0.006 percent and \pm 0.0005 percent in the upper part of this range; the average difference between determinations by chemical and spectrographic methods was about 0.0003 percent of boron.

Variations from nil to 0.006 percent of boron additions made with either simple or complex intensifiers had no significant influence on the following properties of the steels: (1) Cleanliness, except titanium or zirconium inclusions in some steels treated with complex intensifiers (nonmetallic inclusions), (2) hot working (experimental steels), (3) transformation temperatures $\left(A c_{1}, A c_{3}\right.$, $A r_{3}, A r_{1}$ and $A r^{\prime \prime}$, experimental steels), (4) resistance to softening by tempering, (5) weldability (experimental steels), and (6) tensile of fully hardened and tempered specimens, except possibly an improvement in ductility when tempered at low temperatures.

Boron lowers the coarsening temperature of austenite. However, steels with relatively high additions of boron can be rendered fine grained at heat-treating temperatures by the judicious use of grain-growth inhibitors such as aluminum, titanium, and zirconium.

The influence of boron on hardenability and on notch toughness (Charpy impact, $V$-notched specimens) of fully hardened and tempered steels varied with the base composition of the steels, the composition of the intensifiers, and the amount of boron present.

The increase in hardenability due to boron was greater for basic open-hearth than for experimental steels prepared in an induction furnace. The notch toughness at room and low temperatures of the commercial steels fully hardened and tempered at high temperatures was also superior to that of the experimental steels of similar composition heat treated alike.

The hardenability, as determined by the endquench test, of many of the experimental and all the steels comprising a basic open-hearth heat were markedly improved by additions of boron. However, no definite correlation was found be- 
tween the hardenability effect and the amounts of boron added or retained in the steels.

In many of the experimental steels the optimum hardenability was obtained with smáll additions of boron (0.001 percent or less retained), while in other steels the hardenability increased continuously with increase in boron. In other steels, the addition of boron as a simple or complex intensifier was either without effect or impaired the hardenability. In general, relatively small additions were more effective than large, and the complex intensifiers were more effective than the simple ones. The effectiveness of boron in enhancing the hardenability increased with the amounts (within limits) of manganese, chromium, and molybdenum. The hardenability of the boron-treated steels also varied with the state of deoxidation of the heat, and the final nitrogen content. High soluble nitrogen (and possibly oxygen) was detrimental to the boron effect on hardenability, but it was possible to retain the effect in high-nitrogen steels (low-soluble nitrogen) by fixing the nitrogen with strong nitride-forming elements such as titanium or zirconium.

For the commercial steels, the magnitude of the hardenability effect was independent of the amount of boron added or retained and the composition of the intensifiers.

The hardenability of some of the experimental and commercial steels treated with boron was affected by variation in quenching temperatures. In certain steels, the degree of hardenability was increased by increasing the quenching temperature above the usual recommended range, whereas in other steels the hardenability was not affected or was decreased by this change.

The magnitude of the hardenability effect due to boron appears to depend upon the form in which it exists in austenite; not necessarily upon the total amount present.

The addition of small amounts of boron was often beneficial to the notch toughness at room temperature of the steels when fully hardened and tempered at low temperatures.

When the steels were fully hardened and tempered at high temperatures the presence of boron, especially as relatively high additions with intensifiers containing titanium, was usually either without effect or was detrimental to notch toughness at room and subzero temperatures.

The notch toughness of many of the steels fully hardened and tempered at $1,000^{\circ} \mathrm{F}$ was not affected appreciably by a change in test temperature from room to $-95^{\circ} \mathrm{F}$ (see p. 123).

Appreciable amounts of boron were retained in steels after remelting in an induction furnace under both normal and highly oxidizing conditions.

The authors gratefully acknowledge their indebtedness to the many individuals who assisted in preparing and carrying out the test program.

The plans for the investigation were prepared jointly with C. H. Lorig, Battelle Memorial Institute, as the representative of the War Metallurgy Committee. In addition, the plans for obtaining and testing the commercial steels were made with and approved by the Subcommittee on Special Addition Agent Steels of the War Engineering Board, Iron and Steel Committee, R. B. Schenck, Buick Motor Division, General Motors Corporation, Chairman.

The experimental steels were made and analyzed (except for boron and nitrogen) by the members of the staff of the Battelle Memorial Institute, the commercial steels were from a heat made at the Duquesne Works, Carnegie-Illinois Steel Corporation, for the United States Army Ordnance and were analyzed (except for boron and nitrogen) at Buick Motor Division and Battelle Memorial Institute.

The full-time and efficient assistance of G. De Vries, Ellen H. Connelly, H. Hessing and Carolyn $R$. Irish were largely responsible for the completion of the project. Machining of the specimens was done under the supervision of H.J. Kaiser; development of a method for chemical analysis for small amounts of boron and its determination by this method were contributions by H. A. Bright, J. L. Hague, K. D. Fleischer, and Martha S. Richmond; the development of a method for spectrographic analysis for boron and its determination were carried out by B. F. Scribner and C. H. Corliss; determinations for nitrogen by vacuum fusion were made by M. Marie Cron, and its determination by a modified Allen method was made by K. D. Fleischer, all members of the staff of the National Bureau of Standards. 


\section{References}

11] G. K. Burgess and R. W. Woodward, Manufacture and properties of steel plates containing zirconium and other elements, Tech. Pap. BS 16, 123 (1922) T207.

[2] Richard Walter, U. S. Patent No. 1,159,388, filed Aug. 13, 1921, issued Dec. 16, 1924.

[3] T. G. Digges, Influence of variations in boron, carbon, and manganese contents on some properties of steels for armor plate and other military applications, OSRD No. 1159, [M-34] (Jan. 18, 1943).

[4] T. G. Digges, Influence of variations in boron, carbon, and manganese contents on the weldability of steels for armior plate and other military applications, OSRD No. 1282, [M-57] (March 12, 1943).

[5] T. G. I)igges, Influence of nitrogen on some properties of steels with and without boron and titanium additions, OSRD No. 1506, [M-84] (June 3, 1943).

[6] T. G. Digges, Influence of variations in boron, composition of ferroalloys used for making boron additions and deoxidation practice on some properties of experimental steels containing 0.3 percent carbon and 1.6 percent manganese, OSRD No. 1617 [M-96] (July 16, 1943).

[7] T. G. Digges, Influence of boron and nickel on some properties of experimental stcels containing 0.3 percent carbon and 0.8 percent manganese, OSRD No. 1860 [M-128] (Sept. 27, 1943).

[8] T. G. Digges and F. M. Reinhart, Influence of boron and chromium on some properties of experimental steels containing 0.3 percent carbon and $0.8,1.25$, or 1.6 percent manganese, OSRD No. 3020 [M-174: (Dec. 16, 1943).

[9] T. G. Digges and F. M. Reinhart, Influence of nitrogen on some properties of experimental steels without and with boron, OSRD No. 3378 [M-231] (March 15, 1944).

[10] T. G. Digges and F. M. Reinhart, Influence of boron on some properties of experimental steels containing nickel and chromium, OSRD No. 3769 [M-293] (June 10, 1944).

111] T. G. Digges and F. M. Reinhart, Influence of variations in boron and composition of ferroalloys used for making boron additions on some properties of basic open hearth steels containing 0.4 percent carbon and 1.6 percent manganese, OSRD No. 4022 [M-336] (Aug. 9, 1944).
[12] T. G. Digges and F. M. Reinhart, Influence of boron on some properties of experimental steels containing 0.3 percent carbon and varying amounts of manganese, chromium, and molybdenum, OSRD No. 4181 [M-361] (Sept. 25, 1944).

[13] C. H. Corliss and B. F. Scribner, Spectrographic determination of boron in steel, J. Research NBS 36, 351 (1946) RP1705.

[14] A description of the distillation turmeric-method for determining boron as used at the National Bureau of Standards is available in mimeograph form.

[15] A description of the semimicro distillation titration method for determining nitrogen at the National Bureau of Standards is available in mimeograph form.

[16] The effect of mold additions of various "special addition agents", Carnegie-Illinois Steel Corporation Report No. P-3-133 (April 19, 1944).

[17] T. G. Digges, Influence of austenite grain size on the critical cooling rate of high-purity iron-carbon alloys, J. Research NBS 24, 723 (1940) RP1308.

[18] Tentative method of end-quench test for hardenability of steel, ASTM Part 1, Metals. Designation A255-42 T, ASTM Standards 1942, 1106.

[19] M. A. Grossmann, Hardenability calculated from chemical composition, Metals Tech. (June 1942) TP1437.

[20] W. E. Jominy, The Review 17, 9 (March 1944).

[21] J. M. Hodge and M. A. Orehoski, Relationship between hardenability and percentage of martensite in some low-alloy steels, Metals Tech. (Sept. 1945) TP1800.

[22] C. H. Lorig, P. C. Rosenthal, and M. C. Udy, Boron in steel of armor composition, OSRD No. 1834 [M-1401] (Sept. 16, 1943).

[23] R. A. Grange, The effect of boron upon the structure and heat-treating characteristics of steel, OSRD No. 1699 [M-112] (Aug. 4, 1943).

[24] C. E. Jackson and A. I. Cristenson, The effect of quenching temperature on the results of the endquench hardenability test, Trans. AIME, Iron and Steel Division 158, 125 (1944).

[25] H. M. McQuaid, Getting maximum results from carbon and low-alloy steels, Metal Progress 40, 451 (Oct. 1941).

[26] A. B. Kinzel, Trends in alloy steels, Metal Progress 46, 689 (Oct. 1944).

[27] C. H. Lorig, Private communication.

Washington, February 19, 1947. 